Prepared in cooperation with the Mineral Management Division, Hungarian Geological Survey and the United States-Hungarian Science and Technology Joint Fund

\title{
Quality of Selected Hungarian Coals
}

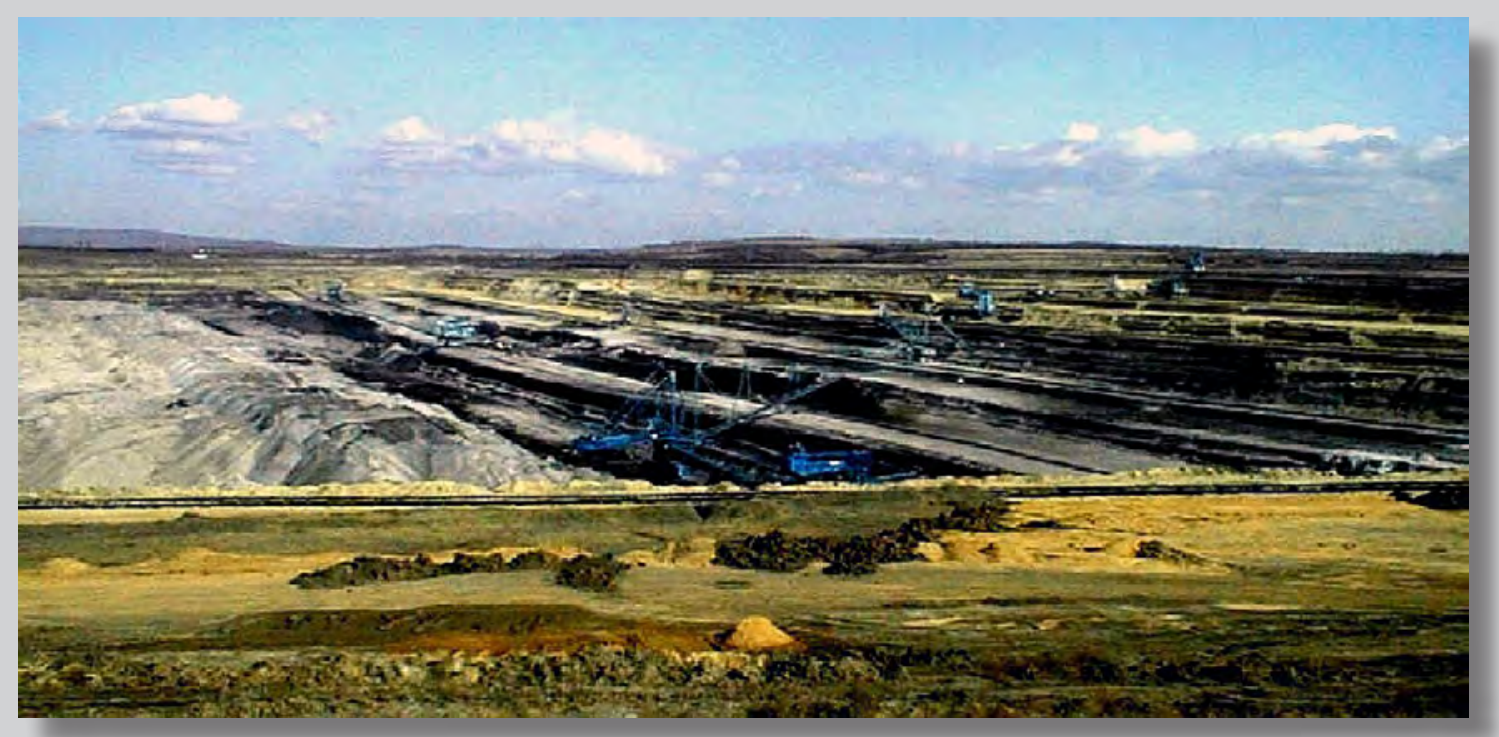

Scientific Investigations Report 2006-5289 


\section{Quality of Selected Hungarian Coals}

By E.R. Landis, T.J. Rohrbacher, H.J. Gluskoter, Bela Fodor, and Gizella Gombar

Prepared in cooperation with the Mineral Management Division, Hungarian Geological Survey, and the

United States-Hungarian Science and Technology Joint Fund

Scientific Investigations Report 2006-5289 


\section{U.S. Department of the Interior DIRK KEMPTHORNE, Secretary}

\section{U.S. Geological Survey \\ Mark D. Myers, Director}

\section{U.S. Geological Survey, Reston, Virginia: 2007}

For product and ordering information:

World Wide Web: http://www.usgs.gov/pubprod

Telephone: 1-888-ASK-USGS

For more information on the USGS--the Federal source for science about the Earth, its natural and living resources, natural hazards, and the environment:

World Wide Web: http://www.usgs.gov

Telephone: 1-888-ASK-USGS

Any use of trade, product, or firm names is for descriptive purposes only and does not imply endorsement by the U.S. Government.

Although this report is in the public domain, permission must be secured from the individual copyright owners to reproduce any copyrighted materials contained within this report.

Suggested citation:

Landis, E.R., Rohrbacher, T.J., Gluskoter, H.J., Fodor, B., and Gombar, G., 2007, Quality of selected Hungarian coals: U.S. Geological Survey Scientific Investigations Report 2006-5289, 107 p. 


\section{Contents}

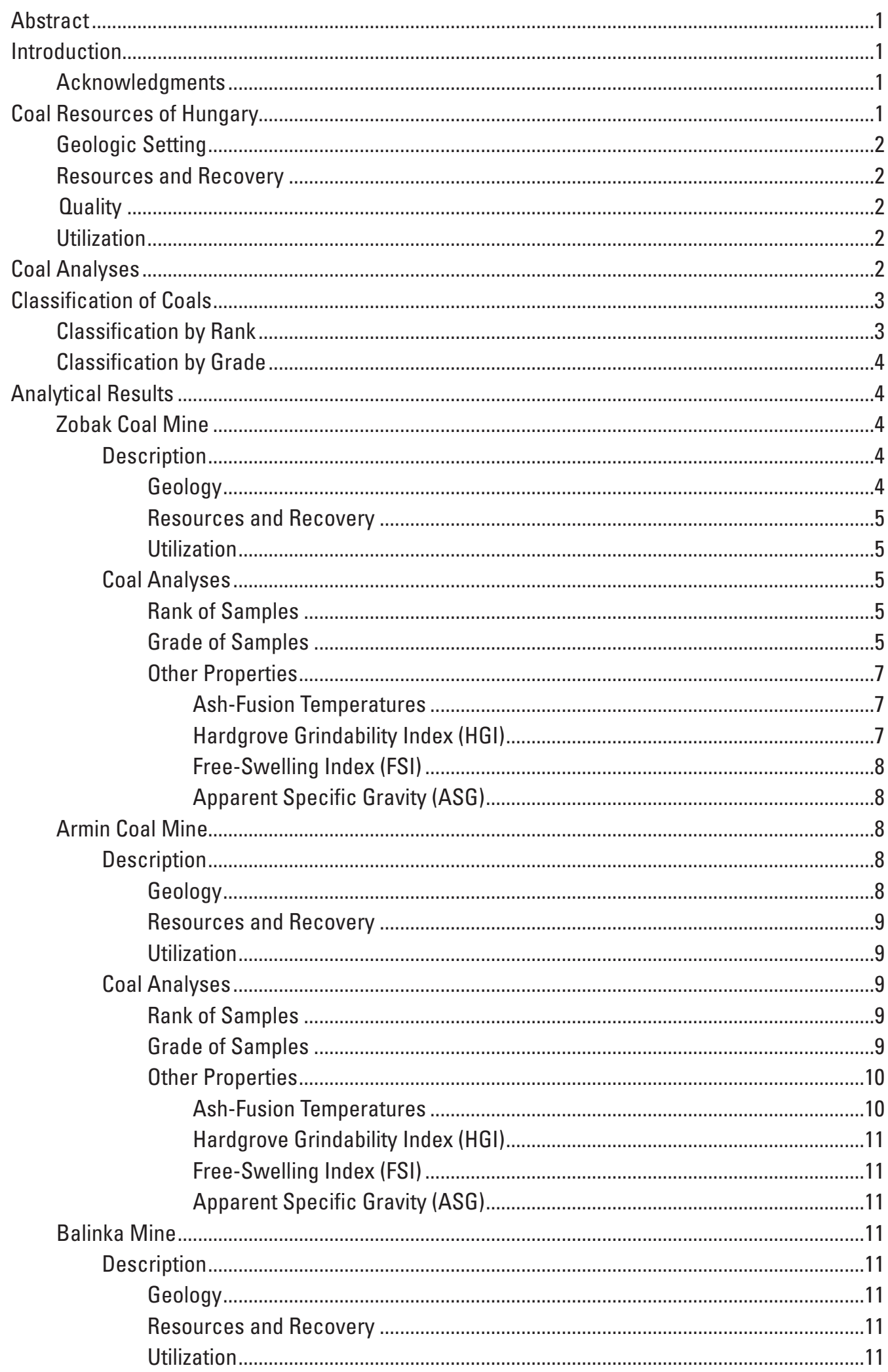




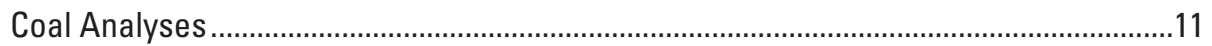

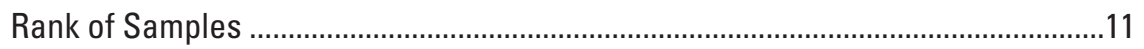

Grade of Samples ............................................................................................

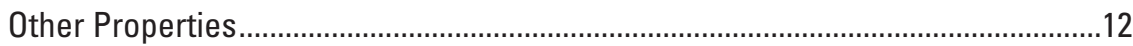

Ash-Fusion Temperatures ...............................................................................12

Hardgrove Grindability Index (HGI) .............................................................12

Free-Swelling Index (FSI) .......................................................................12

Apparent Specific Gravity ...........................................................................12

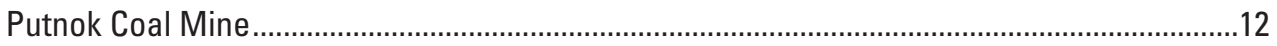

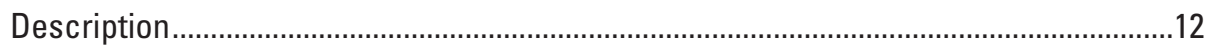

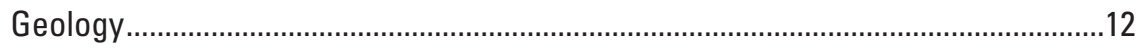

Resources and Recovery .................................................................................14

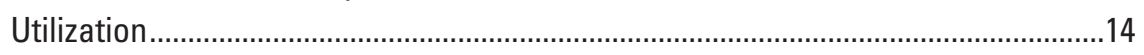

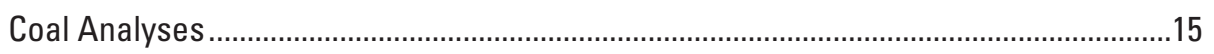

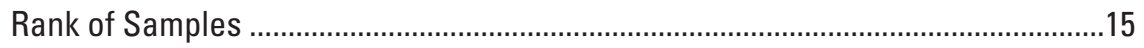

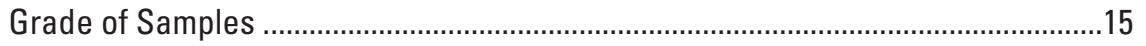

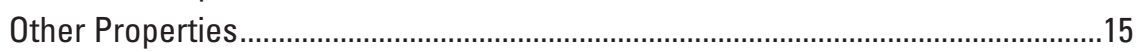

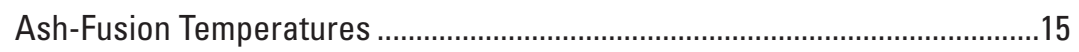

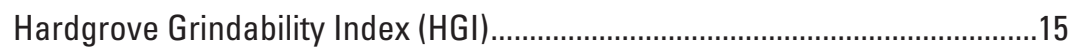

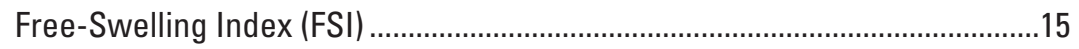

Apparent Specific Gravity (ASG) ..............................................................15

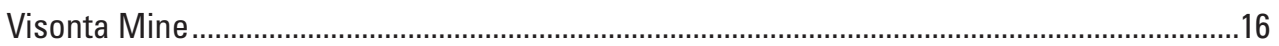

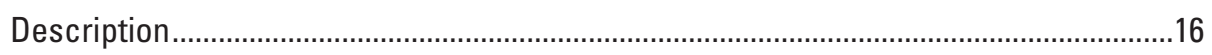

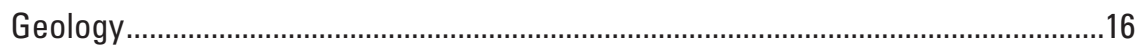

Resources and Recovery ..................................................................................16

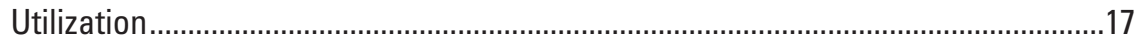

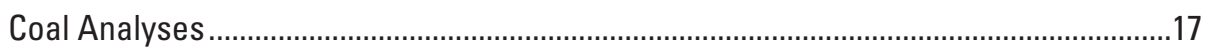

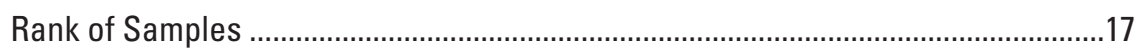

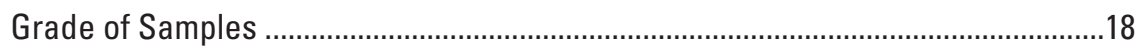

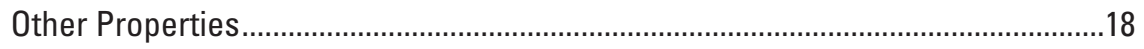

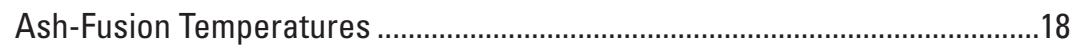

Hardgrove Grindability Index (HGI) ............................................................18

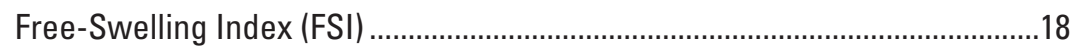

Apparent Specific Gravity (ASG) ................................................................18

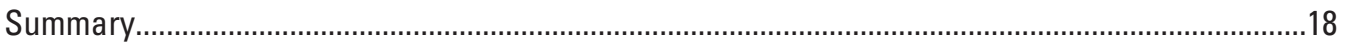

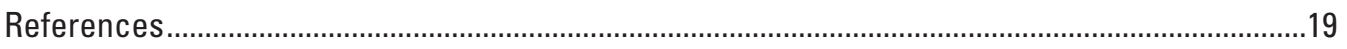

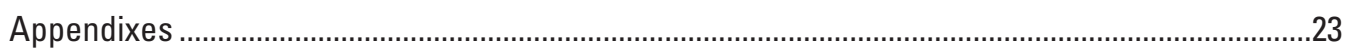

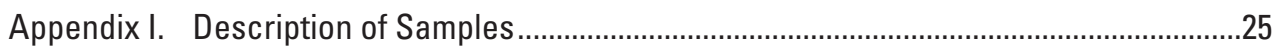

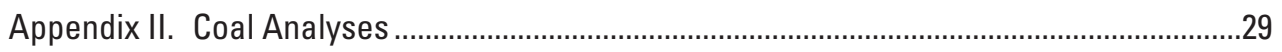

\section{Figures}

1. Map showing Hungarian coal sampling locations and resource areas ..........................2

2. Graph showing terminology for coal rank in Hungary, Germany, and the United States .........................................................................................................

3. Photograph of Visonta Mine, Eastern Lignite Area, Hungary .........................................16 


\section{Tables}

1. Seam-weighted averages (as-received basis) for constituents, calorific values, and forms of sulfur in coals collected from selected mines in Hungary...

2. Proximate and ultimate analyses, calorific values, forms of sulfur, ash-fusion temperatures, Hardgrove grindability indices (HGI), free-swelling indices (FSI), and apparent specific gravities (ASG) in coal samples from the Zoback mine, Hungary

3. Rank classification for coals in the Zobak and Armin mines, Hungary .............................6

4. Ash and sulfur contents of coals and coaly materials sampled in the Zobak and Armin mines, Hungary.

5. Proximate and ultimate analyses, calorific values, forms of sulfur, ash-fusion temperatures, Hardgrove grindability indices (HGI), free-swelling indices (FSI), and apparent specific gravities (ASG) in coal samples from the Armin mine, Hungary

6. Proximate and ultimate analyses, calorific values, forms of sulfur, ash-fusion temperatures, Hardgrove grindability indices (HGI), free-swelling indices (FSI), and apparent specific gravities (ASG) in coal samples from the Balinka mine, Hungary

7. Rank classification for coals in the Balinka, Putnok, and Visonta mines, Hungary ........13

8. Ash and sulfur contents of coals and coaly materials sampled in the Balinka, Putnok, and Visonta mines, Hungary.....

9. Proximate and ultimate analyses, calorific values, forms of sulfur, ash-fusion temperatures, Hardgrove grindability indices (HGI), free-swelling indices (FSI), and apparent specific gravities (ASG) in coal samples from the Putnok mine, Hungary

10. Proximate and ultimate analyses, calorific values, forms of sulfur, ash-fusion temperatures, Hardgrove grindability indices (HGI), free-swelling indices (FSI), and apparent specific gravities (ASG) in coal samples from the Visonta mine, Hungary 


\title{
Quality of Selected Hungarian Coals
}

\author{
By E.R. Landis, ${ }^{1}$ T.J. Rohrbacher, ${ }^{1}$ and H.J. Gluskoter, ${ }^{1}$ Bela Fodor, ${ }^{2}$ and Gizella Gombar ${ }^{2}$
}

\section{Abstract}

As part of a program conducted jointly by the U.S. Geological Survey and the Hungarian Geological Survey under the auspices of the United States-Hungarian Science and Technology Fund, a total of 39 samples from five coal mines in Hungary were selected for analysis. The mine areas sampled represent most of the coal mined recently in Hungary. Almost all the coal is used to generate electricity.

Coals from the five mines (four underground, one surface) reflect differences in age, depositional setting, organic and inorganic components of the original sediments, and deformational history. Classified according to the ranking system of the American Society for Testing and Materials, the coals range in rank from lignite B (Pliocene[?] coals) to high volatile A bituminous (Jurassic coals). With respect to grade classification, based on seam-weighted averages of moisture, ash, and sulfur contents: (1) all contain high moisture (more than 10 percent), (2) all except the Eocene coals are high (more than 15 percent) in ash yield, and (3) two (Jurassic and Eocene coals) are high in sulfur (more than 3 percent) and three (Cretaceous, Miocene, and Pliocene coals) have medium sulfur contents ( 1 to 3 percent). Average heat values range from 4,000 to 8,650 British thermal units per pound.

\section{Introduction}

In 1989, the United States and Hungarian Governments agreed to establish a science and technology joint fund (Joint Fund) to encourage and support a wide range of scientific and technological cooperation. The cooperation is intended to strengthen the bonds of friendship and understanding between the two scientific communities while advancing the state of science and technology to the benefit of both countries.

Joint Fund Project Number 539 was established in 1996 to support cooperation between the Mineral Management Division of the Hungarian Geological Survey and the U.S. Bureau of Mines of the U.S. Department of the Interior.

${ }^{1}$ U.S. Geological Survey.

${ }^{2}$ Hungarian Geological Survey.
In 1996, the U.S. Geological Survey became the cooperating U.S. partner in the project following the dissolution of the U.S. Bureau of Mines. A part of the subsequently undertaken collaborative research was the collection and analysis of samples of coal and associated rock from five mines that produced about one-third of the nation's coal at the time the samples were collected. The results of the analytical program are presented in this report; most of the data in this report were used in preliminary, partial or summary form in earlier reports (Landis and others, 1999, 2000, 2001, 2002a, 2002b, 2003a, 2003b, 2004a, and 2004b).

\section{Acknowledgments}

A study such as this is completely dependent on the sample collection phase of the program. The mine owners, management and technical personnel, and the miners themselves were all helpful, and we offer a sincere thanks to all.

We were ably assisted by personnel of the Todok Briquetting Company in its sample-preparation facilities. We also express our thanks to the many members of the Hungarian Geological Survey and the U.S. Geological Survey who assisted our research endeavors.

\section{Coal Resources of Hungary}

In Hungary, coal has long been known, and mining began in the 18th century; the maximum annual production was in 1964-65, when more than 31 million metric tons was produced. Since then, production has steadily decreased because of the growth in use of gaseous and liquid hydrocarbons, the development of nuclear energy for electrical generation, and the closing of many uneconomic underground coal mines. In 1998, about 15 million tons of coal was produced, of which 92 percent was used to generate electricity.

The energy situation in Hungary remains fluid, with continuing change in the coal industry as (1) subsidies are modified or terminated and uneconomic operations are closed; (2) attempts to rationalize the procurement, distribution, and economics of imported and indigenous natural gas continue; and (3) the possibilities of increasing imports of electricity are investigated. 


\section{Geologic Setting}

Coal has been reported at more than 260 localities in Hungary (Fodor and Gombar, 1999). The well-known localities lie within 11 basins, subbasins, and smaller areas. Figure 1 shows the areas in which coal is known to be present because of exploration activities and also shows the areas in which coal might be present but which are inadequately explored. In addition, there are reports of coal or coaly material at locations outside of the coal areas shown in figure 1 (Radocz, 1982).

The geologic history of Hungary is complex, with many alternating periods of active deposition of sediments followed by tectonic activity and erosion. The coal-bearing rocks, ranging in age from late Carboniferous to Pliocene(?), exhibit this complex history with the older sequences the most likely to be folded, faulted, or locally eroded away and the youngest sequences to be relatively undeformed in comparison. Within the known coal fields, the attitudes of strata range from flatlying to dipping as much as or more than 45 degrees. Faults of larger displacement are commonly reverse faults, and those with smaller offsets are normal faults; but such generalities about structural styles do not everywhere hold true.

\section{Resources and Recovery}

The total geologic resources of coal in Hungary are estimated to be 9,416 million metric tons and the economically extractable reserves to be 2,568 million metric tons (Fodor and Gombar, 1999). About 85 percent of the economically extractable reserves are minable by surface methods. In 1998, 12 of the 27 operating mines were recovering coal by openpit methods, with more than one-half coming from two large surface mines (Visonta and Bukkabrany, fig. 1) producing lignitic coal of Pliocene(?) age. Most of the 15 underground mines in Hungary in 1998 produced less than 1 million tons of coal each (Fodor and Gombar, 1999); many of these have been closed, and in 2004 only 17 mines were active in Hungary, 6 underground and 11 open-pit.

\section{Quality}

The coals of Hungary range in rank from lignite to high volatile bituminous coal (see later discussion). Most of the coal produced at mines typically has high moisture and high to medium ash and sulfur contents.

\section{Utilization}

In 1998, 92 percent of the coal produced in Hungary was used to generate electricity. The remainder was divided about equally between small-scale industrial use (for example, making cement and lime) and domestic use (for example, home heating) (Fodor and Gombar, 1999). About 6 percent of the coal consumed was imported. Many of the coal mines, especially the larger ones, are integrated in operation with a nearby electrical-generation plant. Some of the plants also provide heat to local housing or industries.

\section{Coal Analyses}

The physical and chemical characteristics and properties of organic materials such as coal may be tested and defined in several ways. One of the systems of coal characterization in common use is that developed, and under constant review and revision, by the American Society for Testing and Materials

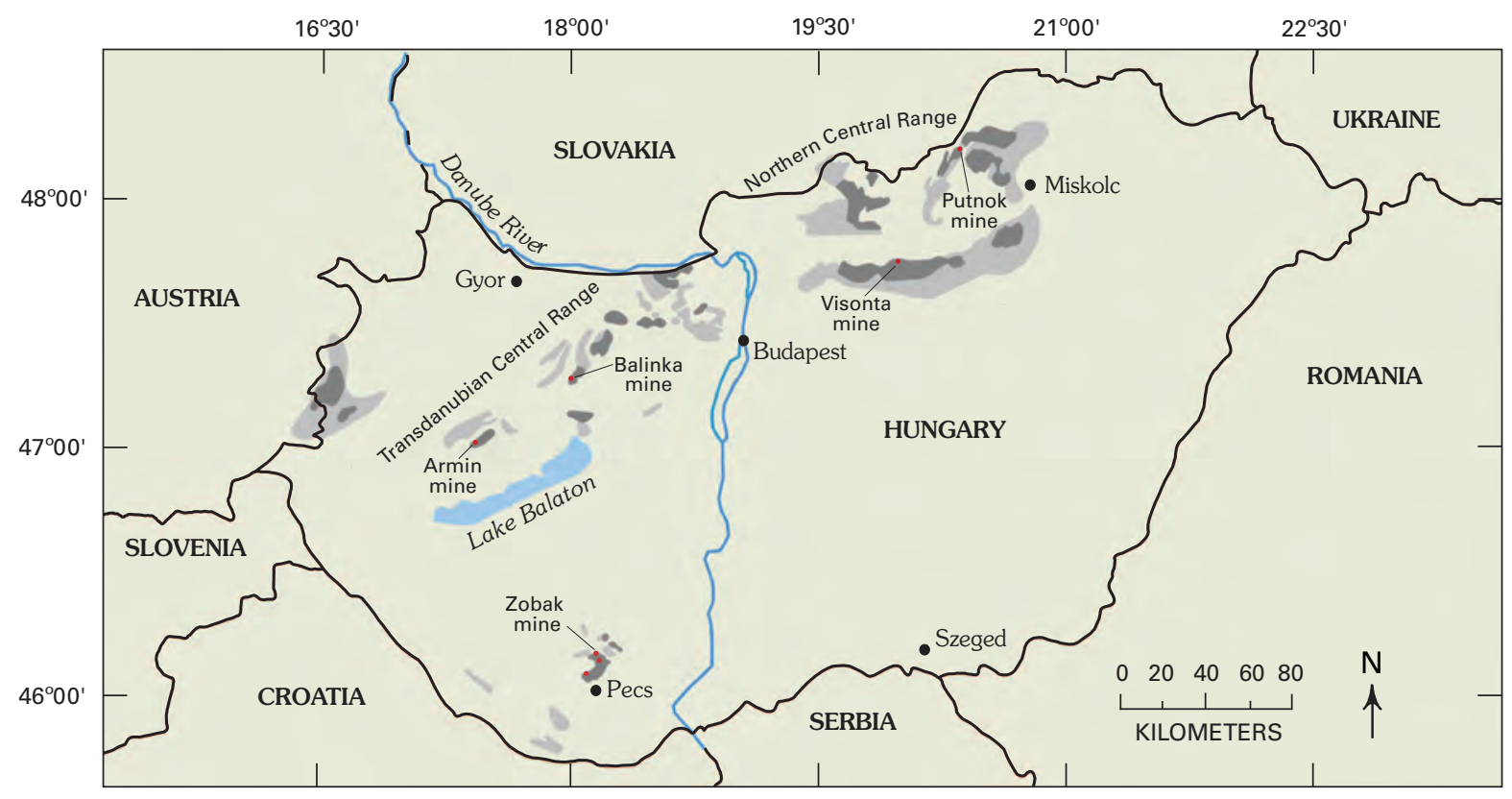

Figure 1. Hungarian coal sampling locations and resource areas. 
(ASTM). Descriptions of standardized tests and analytical procedures are published annually (for example, 1999 Book of ASTM Standards, Section 5, Volume 05.05, Gaseous Fuels: Coal and Coke) Similar systems have been developed by other organizations, such as the International Standards Organization (ISO) (Gluskoter and others, 1981).

The coal analytical data reported herein include proximate and ultimate analyses as well as a variety of other analyses and tests. Typically, the results of tests (as-determined results) are mathematically converted according to standardized formulas presented in ASTM D 3180-89 (American Society for Testing and Materials, 1999) and reported in terms of three conventional formats: (1) as-received_basis, “****analytical data calculated to the moisture condition of the sample as it arrived at the laboratory and before any processing or conditioning"; (2) dry basis, "***data calculated to a theoretical base of no moisture associated with the sample"; and (3) dry, ash-free basis, "***data calculated to a theoretical base of no moisture or ash associated with the sample." The ASTM Standard Test Method used for each analysis or test is included in the reporting of data. These methods are continually reviewed and modified; standards cited in this report were applicable at the time the analyses were performed.

\section{Classification of Coals}

Because of the heterogeneous nature of coal, as reflected in large differences in physical, chemical, and other properties, it is difficult to establish a single classification system that fits all varieties. Currently, three classifications systems are widely used-rank, grade, and type. The first two (rank and grade) will be used to describe the coals discussed in this report; information on the third (type) is unavailable.

\section{Classification by Rank}

Classification by rank is according to the degree of metamorphism in the continuum of physical and chemical change whose end members are peat (biochemically altered plant remains) and graphite (carbon). Classes and groups, and in some cases finer subdivisions, within the rank series have defined boundaries, names and (or) numbers. Two of the commonly used classifications are those applied in Germany and the United States. Hungarian terminology for rank classification is similar to the German system, and the correlative relationship among the three rank classification systems is fairly well understood (fig. 2).

In this report, the terminology of the Standard Classification of Coals by Rank (ASTM D 388-98a; American Society for Testing and Materials, 1999) will be used most of the time, with appropriate cross references. In common usage, Hungarian terms for rank classification are shortened by deletion of the modifiers "fekete" and "barna" (black and brown) and the practice is followed in much of this report.

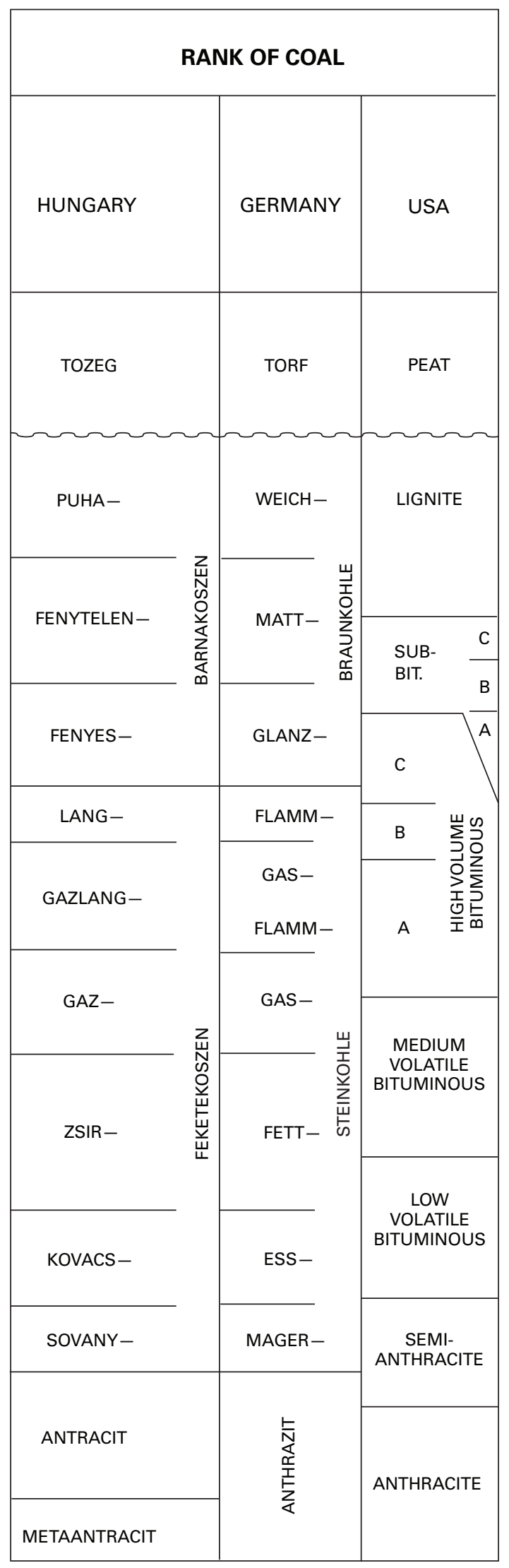

Figure 2. Terminology for coal rank in Hungary, Germany, and the United States. 


\section{Classification by Grade}

Classification of coals by grade is extremely important in attempts to predict the behavior of coals during combustion and conversion processes. Depending on the factors of a particular set of planned utilization procedures, a variety of coal properties and constituents can be of importance. However, three particular coal characteristics - moisture, ash, and sulfur contents - seem to affect virtually all present-day utilization options; they provide the basis for general classification by grade of the coals discussed in this report.

In general, coals with more than about 8 to 10 percent total moisture are considered to be high-moisture, low-rank coals. In the German system of classification, the transition from braunkohle to steinkohle occurs at about 8-10 percent moisture (Taylor and others, 1998).

Wood and others (1983) presented standard grade terminology for ash and sulfur in coals of the United States, as follows:

\section{$\underline{\text { Ash }} \quad \underline{\text { Sulfur }}$}

high, more than 15 percent

high, 3 percent or more

medium, 8 to 15 percent

medium, more than 1 to less than 3 percent

low, less than 8 percent

low, 1 percent or less

\section{Analytical Results}

Samples of the coal-bearing sequences, which are described in Appendix I, were collected following the megascopic-bench sampling method (also called the "increment sampling" method) described by the American Society for Testing and Materials (1999, D5192); analyses are reported in Appendix II. Samples collected by the megascopic-bench sampling method can be used to mathematically construct, or "composite," an analysis that fairly represents the coaly material being mined at the time of sample collection. The calculated seam-weighted (by thickness) averages for various constituents of the coals being mined at the time of sample collection are shown in table 1 . In some cases, not all of the collected samples were used to construct the seam-weighted average; for example, sampled benches constituting the roof of the sequence being mined would not be included in the mathematical process. In other cases, coals in benches that were not sampled have been included in the seam-weighted averages because their physical and chemical characteristics can be assumed on the basis of description at the time of sampling.

Some of the properties listed in Appendix II, specifically ash-fusion temperatures, Hardgrove Grindability Index (HGI), free-swelling index, and apparent specific gravity, are considered to be nonadditive properties (American Society for Testing and Materials, 1999, D5192); averages are not presented for these properties. Verification of these properties for utilization purposes would require further sampling and analyses, such as on a bulk-sample basis.

\section{Zobak Coal Mine}

The Zobak coal mine in the Mecsek Basin of southwestern Hungary was one of several underground mines that operated in the area over a period of about 200 years. Through time, the mines became deeper, mining costs increased, surface mines were developed nearby, and Zobak, the last of the underground mines in the Mecsek Basin, is now closed. Two surface mines in the basin near the city of Pecs (fig. 1) have also recently closed.

\section{Description}

\section{Geology}

The Mecsek Coal Formation comprises a sequence of Upper Triassic and Lower Jurassic rocks composed of sandstone, claystone, and mudstone, with coal seams in the middle and upper (Early Jurassic age ) parts of the formation (Csaszar, 1997). The formation ranges in thickness from $100 \mathrm{~m}$ in the northeastern part of the Mecsek Basin to 1,200 $\mathrm{m}$ in the southwestern part. The coal seams occur in three groups, and the number of individual seams more than $0.5 \mathrm{~m}$ thick ranges between 10 and 38 (Hetenyi, 1964).

The area in which the Mecsek Formation was deposited was considerably larger than that now occupied by the formation. Erosion from Early Cretaceous to Miocene time, plus folding and faulting, combined to limit the area presently underlain by the Mecsek to discrete, isolated tracts. Igneous intrusions of Early Cretaceous and Miocene ages also destroyed the coal in places (Fodor and others, 1998).

Table 1. Seam-weighted averages (as-received basis) for constituents, calorific values, and forms of sulfur in coals collected from selected mines in Hungary.

[All values are in weight percent, except for calorific values which are in Btu/lb; ?, no data]

\begin{tabular}{|c|c|c|c|c|c|c|c|c|c|c|c|c|c|}
\hline \multirow{2}{*}{ Mine } & \multirow{2}{*}{ Moisture } & \multirow{2}{*}{ Ash } & \multirow{2}{*}{$\begin{array}{c}\text { Volatile } \\
\text { matter }\end{array}$} & \multirow{2}{*}{$\begin{array}{l}\text { Fixed } \\
\text { carbon }\end{array}$} & \multirow{2}{*}{ Hydrogen } & \multirow{2}{*}{ Carbon } & \multirow{2}{*}{ Nitrogen } & \multirow{2}{*}{ Sulfur } & \multirow{2}{*}{ Oxygen } & \multirow{2}{*}{$\begin{array}{c}\text { Calorific } \\
\text { value }\end{array}$} & \multicolumn{3}{|c|}{ Forms of sulfur } \\
\hline & & & & & & & & & & & Sulfate & Pyritic & Organic \\
\hline Zobak & 3.4 & 36.9 & 22.7 & 37.0 & 3.6 & 47.3 & 1.0 & 3.7 & 7.5 & 8,650 & 2.05 & 2.46 & 2.86 \\
\hline Armin & 21.9 & 27.7 & 35.8 & 14.6 & 4.5 & 32.2 & 0.5 & 2.2 & 33.0 & 4,800 & 2.52 & 3.42 & 4.31 \\
\hline Putnok & 26.0 & 18.9 & $?$ & $?$ & $?$ & $?$ & $?$ & 2.8 & $?$ & 6,600 & 2.44 & 3.21 & 3.97 \\
\hline Visonta & 43.8 & 20.7 & 22.3 & 13.2 & 6.9 & 23.0 & 0.4 & 1.2 & 47.7 & 4,000 & 0.9 & 1.14 & 1.39 \\
\hline
\end{tabular}


The upper and lower groups of coal seams were deposited in paralic environments, and the seams of the middle group were deposited in limnic environments (Fodor and others, 1998). Seam No. XII, sampled in the Zobak mine for this study, is in the middle coal group in the Komlo area of the Mecsek Basin.

\section{Resources and Recovery}

The total geological coal resources of the Mecsek Basin are estimated at about 1,596 million metric tons and the economically extractable reserves at 199 million metric tons (Fodor and Gombar, 1999).

In 1998, the Zobak mine produced 300,000 metric tons of coal. The mining method employed-low-technology longwall—used tools such as hand-wielded pneumatic picks. The complex geology precluded use of high-technology methods. In addition, mining costs included adequate ventilation to keep the working areas free of explosive quantities of methane gas. During the authors' visit, a hand-held methanometer indicated that the air at the longwall face contained nearly 2 percent methane, and the mine supervisors reported that the air in the caved area behind the longwall face contained 8 to 12 percent methane. Because of the long-known high methane content of the Mecsek coals, there has been considerable interest in developing the coal-bed methane resources. Little exploration has been done, and there is no production to date.

\section{Utilization}

The coal produced from mines in the Mecsek Basin was most recently used to produce electricity and heat at the nearby facility of Pecs Power Plant Company.

\section{Coal Analyses}

Appendix I includes a description of the location, collection procedures, and samples collected from the Zobak mine. Individual sample analyses received from the analytical laboratory are reported in Appendix II. Table 2 shows the analyses of the samples collected in the Zobak mine, on the as-received basis. Seam-weighted averages (table 1) for the mine-run product at the time of description and sampling were calculated using the as-received analyses of units 1 through 10 (samples 1 through 6), totaling $1.81 \mathrm{~m}$, of the sampled sequence (Appendixes I and II) in proportions according to their thickness.

\section{Rank of Samples}

Table 3 shows the rank classification of each of the samples collected in the Zobak mine. Each of the samples represents a bench (portion or increment) of the coal sequence that was exposed in the mine at the time of sampling. Two of the three samples whose ash yield was more than 50 percent (and consequently do not fit the definition of coal) are of lower heat value and erroneously indicate a lower rank than the coal samples. The coal samples are all classified as high volatile A bituminous coal according to the ASTM system and as gazlangkoszen in the Hungarian system. The seamweighted average heat value of the mine-run product is about $8,650 \mathrm{Btu} / \mathrm{lb}$ on the as-received basis.

\section{Grade of Samples}

Classification of samples according to grade is based on the amount of deleterious constituents, usually as weight percent, in the coals. Moisture content, ash yield, and sulfur content are major grade-classification parameters for essentially

Table 2. Proximate and ultimate analyses, calorific values, forms of sulfur, ash-fusion temperatures, Hardgrove grindability indices (HGI), free-swelling indices (FSI), and apparent specific gravities (ASG) in coal samples from the Zoback mine, Hungary.

[Analyses on as-received basis; values are in weight percent, except for calorific values (Btu/lb) and ash-fusion temperatures $\left({ }^{\circ} \mathrm{F}\right)$. V.M., volatile matter; Init, initial temperature; Soft, softening temperature; Hemi, hemispherical temperature; Fluid, fluid temperature]

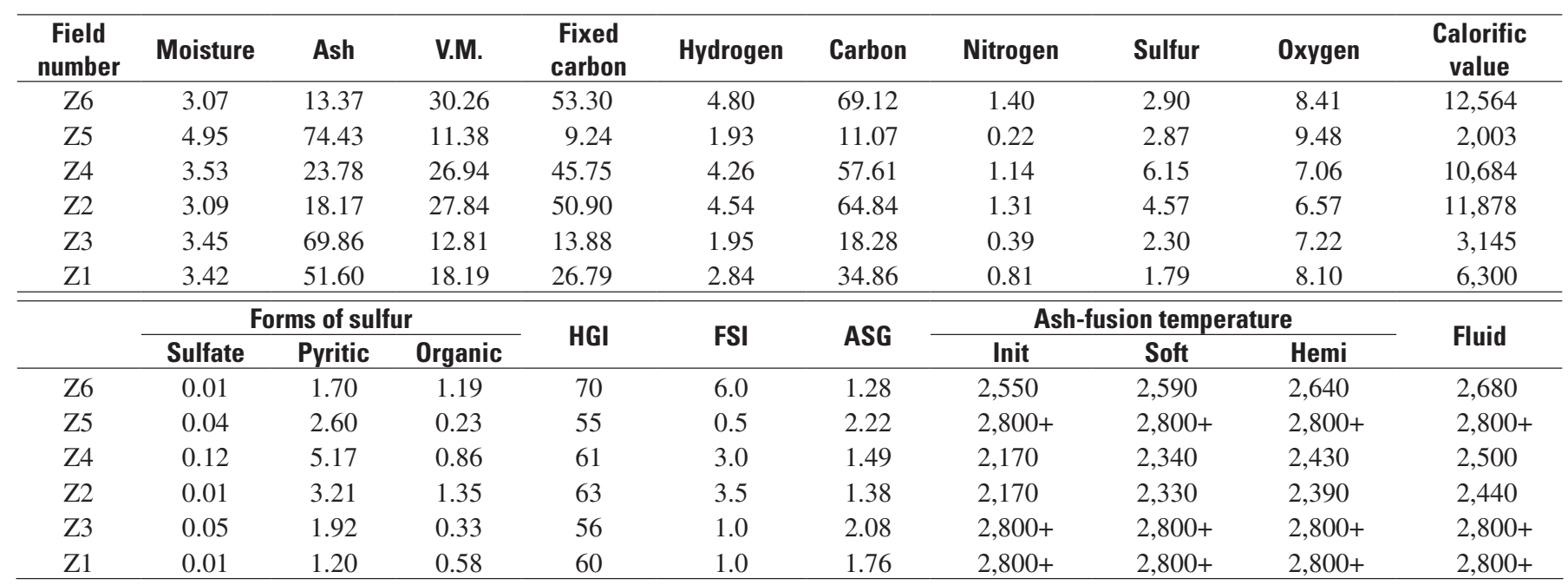


Table 3. Rank classification for coals in the Zobak and Armin mines, Hungary.

[All values are in weight percent, except for heat values (Btu/lb). ASTM, American Society for Testing and Materials; M-M-F, mineral-matter-free; A-F, ash-free]

\begin{tabular}{|c|c|c|c|c|c|c|c|c|}
\hline $\begin{array}{l}\text { Sample } \\
\text { number }\end{array}$ & Lithology & $\begin{array}{l}\text { As-received } \\
\text { ash yield }\end{array}$ & ASTM rank ${ }^{1}$ & $\begin{array}{c}\text { Moist, M-M-F } \\
\text { heat value }\end{array}$ & $\begin{array}{c}\text { Hungarian } \\
\text { rank }^{2}\end{array}$ & $\begin{array}{c}\text { Ash-free } \\
\text { heat value }\end{array}$ & $\begin{array}{c}\text { Dry, A-F } \\
\text { volatile matter }\end{array}$ & $\begin{array}{l}\text { Ash-free } \\
\text { moisture }\end{array}$ \\
\hline \multicolumn{9}{|c|}{ Zoback mine } \\
\hline Z6 & Coal & 13.37 & High volatile A bituminous & 14,790 & Gazlangkoszen & 14,500 & 36.21 & Not usable \\
\hline $\mathrm{Z} 5$ & Coaly claystone & 74.43 & Subbituminous B & 10,309 & Fenytelenkoszen & 7,830 & 55.21 & Not usable \\
\hline $\mathrm{Z} 4$ & Coal & 23.78 & High volatile A bituminous & 14,630 & Gazlangkoszen & 14,020 & 37.06 & Not usable \\
\hline $\mathrm{Z} 2$ & Coal & 18.17 & High volatile A bituminous & 14,960 & Gazlangkoszen & 14,520 & 35.35 & Not usable \\
\hline $\mathrm{Z3}$ & Claystone/coal & 69.86 & High volatile $\mathrm{B}$ bituminous & 13,010 & Fenyeskoszen & 10,430 & 48.01 & Not usable \\
\hline $\mathrm{Z} 1$ & Claystone/coal & 51.6 & High volatile A bituminous & 14,350 & Gazlangkoszen & 13,020 & 40.44 & Not usable \\
\hline \multicolumn{9}{|c|}{ Armin mine } \\
\hline A3 & Marly coal & 37.06 & Lignite B & 4,620 & Puha/Fenytelenkoszen & 4,450 & Not usable & 28.22 \\
\hline A1 & Marly coal & 14.31 & Subbituminous C & 8,790 & Fenytelenkoszen & 8,670 & Not usable & 29.84 \\
\hline $\mathrm{A} 2$ & Coaly marl & 43.36 & Lignite B & 1,330 & ?/Fenytelenkoszen & 1,250 & Not usable & 33.88 \\
\hline A4 & Marly coal/Coal & 12.8 & Subbituminous C & 8,790 & Fenytelenkoszen & 8,680 & Not usable & 30.72 \\
\hline A5 & Marly coal & 36.03 & Lignite B & 4,450 & Puha/Fenytelenkoszen & 4,290 & Not usable & 29.56 \\
\hline A6 & Clayey coal & 13.91 & Subbituminous C & 8,540 & Fenytelenkoszen & 8,440 & Not usable & 30.36 \\
\hline A7 & Coal & 8.61 & Subbituminous C & 8,980 & Fenytelenkoszen & 8,920 & Not usable & 30.88 \\
\hline A8 & Coal & 25.11 & Lignite A & 6,990 & Puha/Fenytelenkoszen & 6,830 & Not usable & 31.43 \\
\hline A9 & Marly coal/Coal & 32.54 & Lignite A & 7,340 & Puha/Fenytelenkoszen & 7,090 & Not usable & 30.42 \\
\hline $\mathrm{A} 10$ & Coal & 16.95 & Subbituminous C & 9,110 & Fenytelenkoszen & 8,960 & Not usable & 29.97 \\
\hline A11 & Marly coal & 26.87 & Lignite A & 7,210 & Puha/Fenytelenkoszen & 7,030 & Not usable & 30.21 \\
\hline $\mathrm{A} 12$ & Coal & 26.73 & Lignite A & 7,440 & Puha/Fenytelenkoszen & 7,250 & Not usable & 29.59 \\
\hline
\end{tabular}

${ }^{1}$ Rank according to a standard classification of the American Society for Testing and Materials (1999), based on the moist, mineral-free heat value in British thermal units per pound (Btu/lb).

${ }^{2}$ Rank according to the Hungarian system, based on the ash-free heat value in British thermal units per pound and the dry, ash-free volatile matter content in weight percent. 
all coals. Table 4 lists these parameters for grade evaluation of the samples from the Zobak mine. According to the German system, the Zobak coals are classified as low-moisture coals.

Three of the six samples have an ash yield of more than 50 percent and two of the three samples classified as coal (less than 50 percent ash yield) have ash yields of more than 15 percent, and the other nearly so. The seam-weighted average ash yield of the sampled sequence is almost 37 percent. The Zobak coals can, therefore, be expected to have high-medium and high ash yields.

As shown in table 4, four of the Zobak samples would be classified as having medium sulfur content and two as having high sulfur content. The total sulfur content of a mine-run product that could be produced from the sampled sequence would be about 3.7 percent on the as-received basis. Most of the sulfur in the Zobak samples is in the pyritic form. The ratio between pyritic and organic sulfur ranges from less than 1.5:1 to more than 11:1. Pyrite was observed in one sample (Z2, Appendix I) but not in the sample containing the most pyritic sulfur. The pyritic sulfur content of a mine-run product would be about 2.8 percent on the as-received basis, and much or most of the sulfur might not be removed during normal coalpreparation processes.

\section{Other Properties}

A large variety of other tests of chemical and physical properties of coals and related materials have been proposed and used to attempt to predict their behavior during various forms of conversion and utilization. Only a few such tests, described below, were conducted during our study. They provide additional characterization of the sampled coals and help guide further specific tests for specialized utilization purposes. As mentioned earlier, the test results for the properties discussed in this section are considered to be nonadditive, so seam-weighted averages have not been calculated.

\section{Ash-Fusion Temperatures}

Gluskoter and others (1981) state that "The softening or fusion temperature of coal ash is the physical characteristic most frequently used as an index of fireside fouling and slagging potential." Desirable ash-fusion characteristics vary, depending on the particular combustion equipment in use or planned. In some uses, formation of clinker masses at low temperatures may be desirable; in other situations the formation of clinker is undesirable and higher ash-fusion temperatures are needed.

Ash-fusion temperatures are commonly determined both in atmospheric conditions that are mildly reducing and in oxidizing atmospheres. The Zobak samples all exhibit high ash-fusion temperatures, and in all samples the temperatures determined under oxidizing conditions are equal to or exceed the temperatures determined under reducing conditions.

\section{Hardgrove Grindability Index (HGI)}

The relative ease with which coals are ground, or pulverized, is an important property in evaluating utilization options In general, the higher the index number resulting from the test, the less energy required to break and pulverize the coal. The HGI of the three Zobak coal samples falls within the range of medium- or low-ash British bright coals, and the three noncoals fall below that range (Brown and Hiorns, 1963).

Table 4. Ash and sulfur contents of coals and coaly materials sampled in the Zobak and Armin mines, Hungary. Percentages of the constituents are used to determine coal grade.

[All values are in weight percent; ?, no data]

\begin{tabular}{|c|c|c|c|c|c|c|c|c|}
\hline \multirow{2}{*}{$\begin{array}{l}\text { Sample } \\
\text { number }\end{array}$} & \multirow{2}{*}{ Lithology } & \multirow{2}{*}{ Moisture } & \multirow{2}{*}{$\begin{array}{l}\text { Equilibrium } \\
\text { moisture }\end{array}$} & \multirow{2}{*}{$\begin{array}{c}\text { Ash } \\
\text { yield }\end{array}$} & \multirow{2}{*}{$\begin{array}{l}\text { Total } \\
\text { sulfur }\end{array}$} & \multicolumn{3}{|c|}{ Forms of sulfur } \\
\hline & & & & & & Sulfate & Pyritic & Organic \\
\hline Z6 & Coal & 3.07 & 2.1 & 13.37 & 2.90 & 0.01 & 1.70 & 1.19 \\
\hline $\mathrm{Z4}$ & Coal & 3.53 & 2.07 & 23.78 & 6.15 & 0.12 & 5.17 & 0.86 \\
\hline $\mathrm{Z} 2$ & Coal & 3.09 & 1.92 & 18.17 & 2.30 & 0.05 & 1.92 & 0.33 \\
\hline $\mathrm{Z} 3$ & Claystone/Coal & 3.45 & 3.01 & 69.86 & 4.57 & 0.01 & 3.21 & 1.35 \\
\hline \multicolumn{9}{|c|}{ Armin mine } \\
\hline A3 & Marly coal & 17.76 & 15.07 & 37.06 & 1.13 & 0.03 & 0.16 & 0.94 \\
\hline $\mathrm{A} 1$ & Marly coal & 25.57 & 25.21 & 14.31 & 3.54 & 0.02 & 0.18 & 3.34 \\
\hline $\mathrm{A} 2$ & Coaly marl & 19.19 & $?$ & 43.36 & 0.01 & $?$ & $?$ & $?$ \\
\hline A4 & Marly coal/Coal & 26.79 & 27.62 & 12.8 & 3.51 & 0.07 & 0.24 & 3.20 \\
\hline A5 & Marly coal & 18.91 & 16.97 & 36.03 & 1.03 & 0.04 & 0.06 & 0.93 \\
\hline A6 & Clayey coal & 26.14 & 28.77 & 13.91 & 3.31 & 0.05 & 0.15 & 3.11 \\
\hline A11 & Marly coal & 22.09 & 22.44 & 26.87 & 2.32 & 0.05 & 0.18 & 2.09 \\
\hline A12 & Coal & 21.68 & 20.86 & 26.73 & 2.28 & 0.06 & 0.28 & 1.94 \\
\hline
\end{tabular}




\section{Free-Swelling Index (FSI)}

The plastic properties of coal are the subject of much research aimed at predicting the behavior of coals in particular utilization processes. Much of this research has been done with regard to making coke for the steel industry, but the results may also apply to other forms of coal utilization. Fluidity measurements are especially important in coke making and are commonly accomplished with plastometers, dilatometers, and penetrometers.

The swelling properties of coal are commonly measured by heating coal at a prescribed rate to $820^{\circ} \mathrm{C}$ and measuring the size of the coke button that is formed (Gluskoter and others, 1981). If the coal is not fusible, which is true of many low-rank coals, the sample remains in powdered form and has an FSI of 0. If the coal is fusible, the sample particles melt, coalesce, and swell. The resulting coke button is compared to standards and assigned a relative number, or FSI.

The three coal samples from the Zobak mine indicate that the Zobak coals have medium to strong coking potential, with the FSI obviously negatively related to the ash yield. The three Zobak samples with ash yields of more than 50 percent continue the negative relation. The correlation coefficient between ash yield and FSI in the Zobak samples is -0.9 .

\section{Apparent Specific Gravity (ASG)}

Specific gravity (the weight per unit volume of a material relative to the weight of a similar volume of water) is termed "apparent" when the measurement includes both the solid matter of the measured material and the pores that have not been invaded and filled by the fluid medium used in the measurement process. True density requires use of a fluid medium that can penetrate and fill the pore spaces in porous material such as coal. Helium is commonly used because the effective diameter of the helium atom is less than 2 angstroms whereas the smallest diameter pores in coal are generally about 5 to 10 angstroms (Tschamler and De Ruiter, 1963). However, apparent specific gravity determined by using water as the fluid medium suffices for most purposes.

Because of their high inorganic content, all but one of the Zobak coal samples exceed the average specific gravity of bituminous coals (1.32) listed by Wood and others (1983). The result is not unexpected, nor uncommon, because specific gravity varies with inorganic matter content (both amount and type) and with the various amounts of the different organic constituents of coals.

\section{Armin Coal Mine}

The Armin coal mine in western Hungary in the Bakony Basin produced coal from rocks of Cretaceous age until recently (2004). These coals have been known for almost 150 years and have been mined for about 130 years.

\section{Description}

\section{Geology}

The coal-bearing Cretaceous rocks of western Hungary are on the west flank of the Transdanubian Central Range (fig. 1). Structurally, they are in a large, ill-defined basin termed the Bakony Basin, within the southwestern part of which there are at least three smaller depositional basins. The Cretaceous strata, containing coal in two of these smaller basins, reflect a complex depositional history within relatively short distances.

The Ajka Coal Formation is of Senonian age, a subseries that composes the upper part of the Upper Cretaceous Series and includes the Coniacian, Santonian, Campanian, and Maastrichtian Stages. The formation is composed of cyclic alternations " $* * *$ of dark clayey coal-bearing strata and pelitic-calcareous-fine siliciclastic layers of lighter shades with intercalations of molluscan coquinas***. Freshwater fossils in the lower part of the succession are replaced by brackish-water biota in the upper part" (Haas and others, 1992). The Ajka was deposited either (1) unconformably on a variety of older rock units, mostly carbonates of Triassic, Jurassic, and Cretaceous age or (2) conformably on clastics of the partly equivalent Csehbanya Formation, with which it laterally interfingers. The Ajka is conformably overlain by the partly equivalent Csehbanya, or other younger units such as the Jako Marl Formation. A detailed reconstruction of the Senonian history of the area in the Bakony Basin that is underlain by Cretaceous coals is provided by Goczan and others (1986).

The rocks described as marl in descriptions of the stratigraphic sequence that was sampled (see Appendix I) are composed of varying amounts of calcium carbonate, much of it in the form of shell material, combined with claystone, siltstone, and coal. The shell material is present both as distinct layers and as isolated, dispersed shell material in other parts of the sampled sequence. As Haas and others (1992) state, "Coal seams frequently alternate with marl layers even within the coal facies."

Haas and others (1992) described the geology of the Ajka and Csehbanya Formations in three areas (which they called depressions or zones). The Armin mine was in the zone or area designated AJKA-1 by Tomschey (1995). The following description of the coal-bearing rocks in the area just southeast of the town of Ajka has been largely derived from Haas and others (1992).

The Ajka Coal Formation is about $100 \mathrm{~m}$ thick and can be divided into five groups of beds, three of which contain coals. The lower coal group contains five designated coal seams (numbered 1-5, in descending order), ranges from 10 to as much as $55 \mathrm{~m}$ thick, and is overlain by a noncoaly sequence 10 to $30 \mathrm{~m}$ thick that is composed largely of clayey marl. The middle coal group, 5 to $12 \mathrm{~m}$ thick, contains impure and clayey coal beds and is overlain by a sequence of noncoaly clay and marl that is 5 to $15 \mathrm{~m}$ thick. The upper coal group, mostly thin and impure coals, is commonly only a few meters 
thick and is absent in much of the area. The lower coal group was deposited in fresh or slightly saline water environments and the middle coal group under mesohaline conditions; the upper coal group is closely associated with marine fossils and sediments.

The coal sequence that was sampled in the Armin mine constitutes part of Bed No. 4 in the lower coal group.

\section{Resources and Recovery}

The Cretaceous coal-bearing rocks in the Bakony Basin contain resources estimated to be about 368 million metric tons. In 1998, the two mines operating in the Ajka area of the basin, the Armin and the adjoining Jokai, had estimated coal resources of about 38.3 million tons and economically extractable reserves of 7.5 million tons (Fodor and Gombar, 1999) Both mines are now closed.

The Armin mine used a blasting-induced sublevel-caving technique to enhance coal recovery from above a normal longwall face. As a first step, coal at the base of the longwall face was extracted by a longwall shear. Then the coal above the roof supports was drilled, blasted, and allowed to cave at the face shields. When noncoal roof rock appeared in the downward flow, dilution was prevented by adjusting the face shield, and the procedure was repeated. The mining method is similar to that used in the Velenje mine in nearby Slovenia, where the coal is as much as $90 \mathrm{~m}$ thick.

The Armin and Jokai mines produced a combined 1.2 million tons of coal in 1998, of which the Armin produced 0.7 million tons. Production costs at these two mines were near the middle of the range of costs for Hungarian coal mines (Fodor and Gombar, 1999).

\section{Utilization}

The coal produced at both the Armin and Jokai Mines was used in the powerplant at Ajka to generate electricity and heat for local purposes.

\section{Coal Analyses}

Appendix I includes a description of the location, collection procedures, and samples collected from the Armin mine; units 2 through 24 comprised the mine-run product at the time of description and sampling. Table 5 shows the analyses of the collected samples, on the as-received basis. All units were not sampled, so analyses of units described as similar to the nonsampled units were substituted during the mathematical process of calculating seam-weighted averages for the mined product (table 1).

\section{Rank of Samples}

Table 3 shows the rank classification of each of the samples collected in the Armin mine. Each of the samples represents a bench, or portion, of the coal sequence that was exposed in the mine at the time of sampling. As described in Appendix I, not all portions of the sequence exposed in the mine were sampled, but representatives of all observed coal and noncoal types are included in the group of analyzed samples.

Descriptions of the coal samples (see Appendix I) and reports of other workers all indicate that a large part of the inorganic material in the Armin coals is calcium carbonate. In most coals of the world, most, and sometimes all, of the inorganic material consists of clays, silicates, and iron sulfide minerals. Classification systems that depend on mineralmatter-free or ash-free parameters were designed to accommodate such coals, but not the coals containing calcium carbonate. One way to incorporate the calcium carbonate-bearing coals into the same classification scheme is to add the weight of the gases produced during coal combustion (mostly carbon dioxide) to the weight of the remaining inorganic material, thus taking into account the total amount of inorganic material in the sample. The $\mathrm{CO}_{2}$ content of the Armin coal samples has not been determined, so their rank classification according to both the ASTM and Hungarian systems could be higher than that listed in table 3 .

A reconstruction of the mine-run product that could be recovered from the sampled sequence in the Armin mine requires assumptions about the properties of the unsampled portions of the sequence, based upon the properties of the analyzed samples. The weighted-mean rank derived through use of relative thickness of portions of the sequence would be lignite $\mathrm{A}$.

\section{Grade of Samples}

Table 4 lists the commonly used grade parameters for the Armin samples. The coals have a high moisture content (more than 10 percent) according to the German system. The weighted-mean as-received moisture content of about 22 percent calculated for the sequence that could have been recovered at the time of sampling is lower than is the case for most coals of lignitic rank. However, the results of the equilibrium moisture determinations (table 4) tend to verify the reported as-received moisture contents of the samples.

The weighted-mean average ash yield derived for the minable sequence that was sampled is 27.7 percent. The range for the 12 analyzed samples is from 8.61 to 43.36 percent. Those samples with an ash yield of more than 25 percent have an average ash yield of more than 30 percent, whereas those with ash yields of less than 17 percent have an average ash yield of about 13 percent.

Previous mention has been made of the calcium carbonate content of the inorganic matter of the sampled sequence. The calcium oxide $(\mathrm{CaO})$ content of the ash yield of analyzed samples ranges from 30 to 54 percent, with a virtual 1:1 correlation between $\mathrm{CaO}$ and ash yield. In some forms of utilization, such as fluidized bed combustion, and in some types of emissions control, such as flue gas-slurry combinations, 
Table 5. Proximate and ultimate analyses, calorific values, forms of sulfur, ash-fusion temperatures, Hardgrove grindability indices (HGI), free-swelling indices (FSI), and apparent specific gravities (ASG) in coal samples from the Armin mine, Hungary.

[Analyses on as-received basis; values are in weight percent, except for calorific values (Btu/lb) and ash-fusion temperatures $\left({ }^{\circ} \mathrm{F}\right)$. V.M., volatile matter; Init, initial temperature; Soft, softening temperature; Hemi, hemispherical temperature; Fluid, fluid temperature; ?, no data]

\begin{tabular}{|c|c|c|c|c|c|c|c|c|c|c|}
\hline $\begin{array}{c}\text { Field } \\
\text { number }\end{array}$ & Moisture & Ash & V.M. & $\begin{array}{c}\text { Fixed } \\
\text { carbon }\end{array}$ & Hydrogen & Carbon & Nitrogen & Sulfur & Oxygen & $\begin{array}{c}\text { Calorific } \\
\text { value }\end{array}$ \\
\hline A3 & 17.76 & 37.06 & 39.35 & 5.83 & 3.25 & 23.78 & 0.30 & 1.13 & 34.48 & 2,798 \\
\hline A1 & 25.57 & 14.31 & 32.65 & 27.47 & 5.74 & 43.37 & 0.72 & 3.54 & 32.32 & 7,433 \\
\hline A4 & 26.79 & 12.80 & 32.35 & 28.06 & 5.98 & 43.70 & 0.88 & 3.51 & 33.13 & 7,579 \\
\hline A5 & 18.91 & 36.03 & 40.22 & 4.84 & 3.41 & 23.34 & 0.25 & 1.03 & 35.94 & 2,746 \\
\hline A6 & 26.14 & 13.91 & 33.31 & 26.64 & 5.76 & 42.65 & 0.70 & 3.31 & 33.67 & 7,269 \\
\hline A9 & 20.52 & 32.54 & 34.92 & 12.02 & 4.24 & 30.83 & 0.55 & 2.79 & 29.05 & 4,786 \\
\hline A 10 & 24.89 & 16.95 & 32.41 & 25.75 & 5.72 & 42.68 & 0.87 & 3.79 & 29.99 & 7,440 \\
\hline A11 & 22.09 & 26.87 & 35.58 & 15.46 & 4.50 & 33.23 & 0.54 & 2.32 & 32.54 & 5,141 \\
\hline \multirow[t]{2}{*}{ A12 } & 21.68 & 26.73 & 35.83 & 15.76 & 4.60 & 34.21 & 0.62 & 2.28 & 31.56 & 5,313 \\
\hline & \multicolumn{3}{|c|}{ Forms of sulfur } & HGI & FSI & ASG & \multicolumn{4}{|c|}{ Ash-fusion temperature } \\
\hline A4 & 0.07 & 0.24 & 3.20 & $?$ & 0.0 & 1.31 & 2,440 & 2,570 & 2,580 & 2,620 \\
\hline A5 & 0.04 & 0.06 & 0.93 & $?$ & 0.0 & 1.93 & 2,680 & 2,700 & 2,710 & 2,720 \\
\hline A6 & 0.05 & 0.15 & 3.11 & $?$ & 0.0 & 1.28 & 2,770 & 2,780 & 2,790 & 2,800 \\
\hline A7 & 0.02 & 0.20 & 3.29 & 49.00 & 0.0 & 1.31 & 2,580 & 2,600 & 2,610 & 2,620 \\
\hline A8 & 0.03 & 0.07 & 1.83 & $?$ & 0.0 & 1.32 & 2,760 & 2,780 & 2,790 & 2,800 \\
\hline A9 & 0.19 & 0.98 & 1.62 & $?$ & 0.0 & 1.60 & 2,580 & 2,610 & 2,620 & 2,630 \\
\hline A10 & 0.07 & 0.42 & 3.30 & $?$ & 0.0 & 1.26 & 2,490 & 2,570 & 2,610 & 2,650 \\
\hline A11 & 0.05 & 0.18 & 2.09 & $?$ & 0.0 & 1.58 & 2,710 & 2,730 & 2,740 & 2,750 \\
\hline A12 & 0.06 & 0.28 & 1.94 & $?$ & 0.0 & 1.54 & 2,610 & 2,650 & 2,660 & 2,670 \\
\hline
\end{tabular}

calcium carbonate is added to the system to control sulfur emissions resulting from burning medium and high sulfur coals. Thus, the calcium carbonate in the Armin coals might be environmentally beneficial.

The weighted-average total sulfur content of a mined product from the sampled sequence is 2.2 percent, about in the middle of the medium sulfur content range (Wood and others, 1983). However, the weighted-average organic sulfur content is about 1.85 percent, and only about 0.28 percent of the total sulfur is pyritic.

As shown in table 4, the group of samples with more than 25 percent ash yield has an average total sulfur content of 1.64 percent, whereas the group of samples with less than 17 percent ash yield has an average total sulfur content of 3.53 percent. Correlation analysis shows that the ash yield/ total sulfur relation is strongly negative, the ash yield/pyritic sulfur relation is weakly positive, and the ash yield/organic sulfur relation is strongly negative. The indication is that most of the total sulfur and almost all of the organic sulfur express strong organic affinities. Standard coal-cleaning practices designed to reduce the sulfur content of coals before combustion are both inefficient and inappropriate for coals in which the bulk of the sulfur is in the organic form.
From a grade standpoint, the samples from the Armin mine would be classed as high moisture, high ash, medium sulfur coals.

\section{Other Properties}

\section{Ash-Fusion Temperatures}

In comparison with the other low-rank coals (those from the Balinka, Putnok, and Visonta mines), the coal samples from the Armin mine have the highest ash-fusion temperatures at each measurement point (table 5 and others). Some other low-rank coals, particularly lignitic coals, with high calcium oxide contents in the ash have been reported to exhibit low fusion temperatures, which can lead to problems in boiler design and function (Reid, 1981). However, correlation coefficients between the ash yield and ash-fusion temperatures of the Armin coal samples indicate only weak positive relations between the two parameters (correlation coefficients of +0.23 to +0.33 ). In addition, the group of samples with higher ash yields (greater than 25 percent) have average fusion temperatures only slightly greater than the average fusion temperatures of the samples with lower ash yields (less than 17 percent). 


\section{Hardgrove Grindability Index (HGI)}

Only one of the Armin samples was of sufficient volume to allow determination of the HGI. The resulting determination, 49, implies that the Armin coals are tough rather than brittle and may be similar to all the other samples discussed in this report except those samples from the Zobak mine.

\section{Free-Swelling Index (FSI)}

All of the Armin samples have an FSI of zero, indicating essentially no agglomerating properties.

\section{Apparent Specific Gravity (ASG)}

The apparent specific gravity of the Armin samples ranges between 1.26 and 1.93. As expected, for the samples as a whole, the apparent specific gravity has a positive relation with the amount of ash yield of the samples, with a correlation coefficient of +0.84 . However, the group of samples with ash yields of more than 25 percent has an even stronger positive relation between ash yield and specific gravity (correlation coefficient of +0.86) whereas the samples with less than 17 percent ash yield have a corresponding relation of almost zero (correlation coefficient of -0.02 ).

\section{Balinka Mine}

The Balinka mine, in the northeastern part of the Bakony Basin in western Hungary, was opened in 1952 and closed in 2003.

\section{Description}

\section{Geology}

The coal-bearing rocks in the Balinka coal area are of middle Eocene age and are included in the Dorog Formation of late Lutetian age. The middle Eocene coal-bearing rocks unconformably overlie Upper Triassic limestone and Cretaceous marl, limestone, and claystone and are overlain uncomformably by upper Eocene clay and marl, Oligocene and Miocene sedimentary rocks, and Quaternary sediments. Folding and faulting occurred both before and after deposition of the coal-bearing rocks, resulting in a complex geologic history of the Balinka coal area.

The Eocene rocks range in thickness from about $125 \mathrm{~m}$ to nearly $350 \mathrm{~m}$. The lower part of the sequence contains a unit of sandstone, shale, and coal about $30 \mathrm{~m}$ to $35 \mathrm{~m}$ thick that is commonly overlain by marl. Within the coaly sequence, three relatively persistent coal beds are recognized and numbered in descending order. At the top, Bed I, as much as $4.5 \mathrm{~m}$ thick, is economically the most important bed of the three. It characteristically is present in two benches separated by marl, with the lower bench being the thickest: samples collected for this study are from the lower bench (see Appendix I for detailed description). In the southwestern part of the Balinka coal area, Bed III also attains minable thickness.

\section{Resources and Recovery}

The coal resources of the Balinka mine were about 75 million metric tons, and the economically extractable reserves were about 14 million tons (Fodor and Gombar, 1999). The Balinka mine produced about 0.4 million tons of coal in both 1998 and 1999 and at the time of sampling was operating in an area designated Balinka II. An adjoining area, Balinka III, is yet to be developed.

Coal was recovered by use of a conventional longwall mining method. The sequence described and sampled for this report was exposed in a longwall face about one kilometer northwest of Shaft II.

\section{Utilization}

Most of the coal produced at the Balinka mine was used in the Inota powerplant of the Bakony Power Plant Ltd. to produce electricity and heat for local consumption.

\section{Coal Analyses}

Appendix I includes a description of the location, collection procedures, and samples collected in the Balinka mine, and individual sample analyses are given in table 6 and in Appendix II. At the time of description and sampling, the mine-run product was composed of units 2 through 6 (samples 2 through 6) (Appendix I), and the seam-weighted averages were calculated using the analyses of these units on the as-received basis (Appendix II).

\section{Rank of Samples}

Table 7 shows the rank classification of each of the samples collected in the Balinka mine. Each of the samples represents a bench, or portion, of the coal sequence that was exposed in the mine at the time of sampling. The mine-run product from the sampled sequence included the material represented by the lower five samples (Appendix I) plus a small amount of the overlying coaly marl that is represented by the uppermost sample. In deriving seam-weighted averages to recreate a probable product, it was assumed that little if any of the overlying marl would be included in the mine-run product.

The coaly marl at the top of the described sequence is unusable for rank classification because the determined ash yield does not reliably represent the amount of inorganic material in the sample. All of the other samples indicate an apparent rank of Subbituminous C or Fenytelenbarnakoszen.

\section{Grade of Samples}

Table 8 lists the commonly used grade parameters for the Balinka samples. The coals have high moisture content (more than 10 percent) according to the German system. 
Table 6. Proximate and ultimate analyses, calorific values, forms of sulfur, ash-fusion temperatures, Hardgrove grindability indices (HGI), free-swelling indices (FSI), and apparent specific gravities (ASG) in coal samples from the Balinka mine, Hungary.

[Analyses on as-received basis; values are in weight percent, except for calorific values (Btu/lb) and ash-fusion temperatures $\left({ }^{\circ} \mathrm{F}\right)$. V.M., volatile matter; Init, initial temperature; Soft, softening temperature; Hemi, hemispherical temperature; Fluid, fluid temperature; ?, no data]

\begin{tabular}{|c|c|c|c|c|c|c|c|c|c|c|}
\hline $\begin{array}{c}\text { Field } \\
\text { number }\end{array}$ & Moisture & Ash & V.M. & $\begin{array}{l}\text { Fixed } \\
\text { carbon }\end{array}$ & Hydrogen & Carbon & Nitrogen & Sulfur & Oxygen & $\begin{array}{c}\text { Calorific } \\
\text { value }\end{array}$ \\
\hline B1 & 10.37 & 61.47 & 30.48 & -2.32 & 1.60 & 9.51 & 0.03 & 1.78 & 25.61 & 293 \\
\hline B2 & 22.56 & 17.50 & 33.93 & 26.01 & 5.77 & 41.17 & 0.52 & 4.16 & 30.88 & 7,318 \\
\hline B4 & 24.93 & 9.85 & 36.54 & 28.68 & 6.13 & 46.06 & 0.80 & 4.16 & 33.00 & 8,125 \\
\hline B5 & 25.15 & 10.10 & 35.88 & 28.87 & 6.07 & 45.93 & 0.80 & 4.15 & 32.95 & 8,132 \\
\hline \multirow[t]{3}{*}{ B6 } & 21.97 & 20.39 & 32.52 & 25.12 & 5.48 & 39.28 & 0.75 & 3.78 & 30.32 & 6,973 \\
\hline & \multicolumn{3}{|c|}{ Forms of sulfur } & \multirow{2}{*}{ HGI } & \multirow{2}{*}{ FSI } & \multirow{2}{*}{ ASG } & \multicolumn{4}{|c|}{ Ash-fusion temperature } \\
\hline & Sulfate & Pyritic & Organic & & & & Init & Soft & Hemi & Fluid \\
\hline B1 & 0.09 & 1.55 & 0.14 & $?$ & 0.0 & 2.08 & 2,240 & 2,260 & 2,270 & 2,280 \\
\hline B2 & 0.03 & 0.51 & 3.62 & 49 & 0.0 & 1.40 & 2,190 & 2,250 & 2,260 & 2,450 \\
\hline B3 & 0.03 & 0.35 & 3.24 & 44 & 0.0 & 1.37 & 2,280 & 2,370 & 2,380 & 2,470 \\
\hline B4 & 0.02 & 0.48 & 3.66 & 43 & 0.5 & 1.35 & 2,270 & 2,320 & 2,340 & 2,370 \\
\hline
\end{tabular}

The weighted-mean, as-received moisture content of about 24 percent calculated for the sequence that could have been recovered at the time of sampling is similar to the moisture content expected for coals of this rank. The equilibrium moisture determinations verify the reported as-received moisture contents of the samples.

The six samples would be classified as medium (one sample) and high (five samples) ash according to Wood and others (1983). The mine-run product that could have been derived from the sampled sequence would have an ash yield of about 13 percent and hence would be classed as having medium ash content.

All five of the samples described as coal (Appendix I and table 8) have total sulfur contents near or exceeding 4 percent, and 80 to 90 percent of the total sulfur is in the organic form. In contrast, the coaly marl overlying the coals has almost 90 percent of the total sulfur in the pyritic form. The total sulfur content and the organic sulfur content of the samples have negative relationships to the ash yield, and the pyritic sulfur content has a very strong positive relationship to the ash yield.

\section{Other Properties}

\section{Ash-Fusion Temperatures}

The ash-fusion temperatures of the samples from the Balinka mine show a negative linear relation, with correlation coefficients ranging from -0.33 to -0.79 , between the ash yield and the various determined fusion temperatures. This situation is the reverse of that observed in the suites of samples from both the Zobak and Armin mines. As mentioned earlier, the amount and forms of the parent organic and inorganic material is critically important to the behavior of coals undergoing combustion.

\section{Hardgrove Grindability Index (HGI)}

The HGIs of the Balinka samples indicate that the coal tends to be tough rather than brittle, which is a common characteristic of low-rank coals.

\section{Free-Swelling Index (FSI)}

Three of the six samples from the Balinka mine have FSIs of slightly more than zero, which may not be of any consequence in the coal's utilization.

\section{Apparent Specific Gravity}

The apparent specific gravity determinations for the Balinka samples ranged from 1.28 to 2.08 and show nearly 1:1 correlation between ash yield and apparent specific gravity.

\section{Putnok Coal Mine}

The Putnok Coal mine in the northern part of the Borsod Basin of northern Hungary closed in 2001. In the past, many underground mines operated in the basin to support heavy industry in the area. In 2004, only one large underground mine (more than one million tons annually) and five surface mines were operating.

\section{Description}

\section{Geology}

The Putnok mine recovered coal from the Salgotarjan Brown Coal Formation of early Miocene age. The formation is a generally transgressive sequence deposited mostly during the Ottnangian Stage, with some younger Karpatian 
Table 7. Rank classification for coals in the Balinka, Putnok, and Visonta mines, Hungary.

[All values are in weight percent, except for heat values (Btu/lb). ASTM, American Society for Testing and Materials; M-M-F, mineral-matter-free; A-F, ash-free]

\begin{tabular}{|c|c|c|c|c|c|c|c|c|}
\hline $\begin{array}{l}\text { Sample } \\
\text { number }\end{array}$ & Lithology & $\begin{array}{c}\text { As-received } \\
\text { ash yield }\end{array}$ & ASTM rank ${ }^{1}$ & $\begin{array}{c}\text { Moist, M-M-F } \\
\text { heat value }\end{array}$ & Hungarian rank ${ }^{2}$ & $\begin{array}{c}\text { Ash-free } \\
\text { heat value }\end{array}$ & $\begin{array}{c}\text { Dry, A-F } \\
\text { volatile matter }\end{array}$ & $\begin{array}{l}\text { Ash-free } \\
\text { moisture }\end{array}$ \\
\hline \multicolumn{9}{|c|}{ Balinka mine } \\
\hline B1 & Coaly marl & 61.47 & Lignite B & 630 & Tozeg? & 760 & Not used & 26.91 \\
\hline B2 & Coal & 17.5 & Subbituminous C & 9,020 & Fenytelenkoszen & 8,870 & Not used & 27.35 \\
\hline B3 & Coal & 9.89 & Subbituminous C & 9,430 & Fenytelenkoszen & 9,340 & Not used & 27.11 \\
\hline B4 & Coal & 9.85 & Subbituminous C & 9,090 & Fenytelenkoszen & 9,010 & Not used & 27.65 \\
\hline B5 & Coal & 10.1 & Subbituminous C & 9,130 & Fenytelenkoszen & 9,050 & Not used & 27.98 \\
\hline B6 & Clayey coal & 20.39 & Subbituminous C & 8,940 & Fenytelenkoszen & 8,760 & Not used & 27.6 \\
\hline \multicolumn{9}{|c|}{ Putnok mine } \\
\hline P6 & Coal & 18.31 & Lignite A & 8,180 & Fenytelenkoszen & 8,050 & Not used & 31.81 \\
\hline $\mathrm{P} 4$ & Coal & 13.11 & Lignite A & 8,190 & Fenytelenkoszen & 8,110 & Not used & 31.95 \\
\hline $\mathrm{P} 2$ & Coal & 15 & Lignite A & 8,250 & Fenytelenkoszen & 8,150 & Not used & 32.41 \\
\hline \multicolumn{9}{|c|}{ Visonta mine } \\
\hline V12 & Coal & 5.48 & Lignite B & 5,890 & Puhakoszen & 5,880 & Not used & 47.76 \\
\hline V11 & Clayey coal & 48.55 & Lignite B & 4,170 & Tozeg & 3,880 & Not used & 58.89 \\
\hline V10 & Coal & 16.08 & Lignite B & 5,690 & Puhakoszen & 5,650 & Not used & 50.79 \\
\hline V9 & Clayey coal & 49.58 & Lignite B & 3,560 & Tozeg & 3,330 & Not used & 64.44 \\
\hline V8 & Coal & 21.65 & Lignite B & 5,060 & Puhakoszen & 4,980 & Not used & 56.59 \\
\hline V7 & Coaly claystone & 52.06 & Lignite B & 2,530 & Tozeg & 2,330 & Not used & 73.49 \\
\hline V6 & Coal & 15.38 & Lignite B & 5,450 & Puhakoszen & 5,410 & Not used & 53.1 \\
\hline V5 & Clayey coal & 44.97 & Lignite B & 3,530 & Tozeg & 3,320 & Not used & 66.6 \\
\hline V4 & Coal & 13.39 & Lignite B & 5,250 & Puhakoszen & 5,220 & Not used & 55.26 \\
\hline V3 & Clayey coal & 39.93 & Lignite B & 3,680 & Tozeg & 3,510 & Not used & 66.06 \\
\hline $\mathrm{V} 2$ & Coal & 9.42 & Lignite B & 5,230 & Puhakoszen & 5,230 & Not used & 53.43 \\
\hline V1 & Coal & 15.17 & Lignite B & 5,030 & Puhakoszen & 5,000 & Not used & 56.78 \\
\hline
\end{tabular}

${ }^{1}$ Rank according to a standard classification of the American Society for Testing and Materials (1999), based on the moist, mineral-free heat value in Btu/lb. 
Table 8. Ash and sulfur contents of coals and coaly materials sampled in the Balinka, Putnok, and Visonta mines, Hungary. Percentages of the constituents are used to determine coal grade.

[All values are in weight percent]

\begin{tabular}{|c|c|c|c|c|c|c|c|c|}
\hline \multirow{2}{*}{$\begin{array}{l}\text { Sample } \\
\text { number }\end{array}$} & \multirow{2}{*}{ Lithology } & \multirow{2}{*}{ Moisture } & \multirow{2}{*}{$\begin{array}{c}\text { Equilibrium } \\
\text { moisture }\end{array}$} & \multirow{2}{*}{$\begin{array}{l}\text { Ash } \\
\text { yield }\end{array}$} & \multirow{2}{*}{$\begin{array}{l}\text { Total } \\
\text { sulfur }\end{array}$} & \multicolumn{3}{|c|}{ Forms of sulfur } \\
\hline & & & & & & Sulfate & Pyritic & Organic \\
\hline B1 & Coaly marl & 10.37 & 4.48 & 61.47 & 1.78 & 0.09 & 1.55 & 0.14 \\
\hline B3 & Coal & 24.43 & 23.20 & 9.89 & 3.62 & 0.03 & 0.35 & 3.24 \\
\hline B4 & Coal & 24.93 & 24.34 & 9.85 & 4.16 & 0.02 & 0.48 & 3.66 \\
\hline B5 & Coal & 25.15 & 24.39 & 10.10 & 4.15 & 0.02 & 0.44 & 3.69 \\
\hline P6 & Coal & 25.81 & 25.47 & 18.31 & 3.26 & 0.05 & 1.11 & 2.10 \\
\hline $\mathrm{P} 4$ & Coal & 27.76 & 27.00 & 13.11 & 3.21 & 0.06 & 1.47 & 1.68 \\
\hline $\mathrm{P} 2$ & Coal & 27.55 & 27.21 & 15.00 & 2.25 & 0.05 & 1.08 & 1.12 \\
\hline \multicolumn{9}{|c|}{ Visonta mine } \\
\hline V12 & Coal & 45.14 & 42.70 & 5.48 & 0.58 & 0.02 & 0.03 & 0.53 \\
\hline V7 & Coaly claystone & 35.23 & 34.13 & 52.06 & 0.29 & 0.03 & 0.21 & 0.05 \\
\hline V6 & Coal & 44.93 & 42.66 & 15.38 & 1.78 & 0.14 & 0.91 & 0.73 \\
\hline V5 & Clayey coal & 36.65 & 35.11 & 44.97 & 0.46 & 0.04 & 0.21 & 0.21 \\
\hline V4 & Coal & 47.86 & 43.26 & 13.39 & 1.44 & 0.09 & 0.57 & 0.78 \\
\hline V3 & Clayey coal & 39.68 & 36.07 & 39.93 & 0.47 & 0.03 & 0.19 & 0.25 \\
\hline $\mathrm{V} 2$ & Coal & 48.40 & 45.20 & 9.42 & 2.10 & 0.20 & 1.06 & 0.84 \\
\hline V1 & Coal & 48.17 & 44.37 & 15.17 & 1.35 & 0.08 & 0.71 & 0.56 \\
\hline
\end{tabular}

strata included in some areas. In general, deposition was in freshwater, brackish, and marine environments, in ascending order. However, the transgression was oscillatory, and coal-forming swamp conditions were frequently interrupted by incursions of brackish and shallow marine waters (Radocz and others, 1987). The lower part of the Salgotarjan contains five main coal seams in the eastern part of the basin and three main coal seams in the western part. The formation overlies a terrestrial surface largely occupied by the Gyulakeszi Rhyolite Tuff Formation of early Miocene age (Bohn-Havas and others, 1995) and is overlain by younger Miocene rocks.

The Salgotarjan Brown Coal Formation is predominantly claystone, siltstone, and sandstone and exceeds $300 \mathrm{~m}$ in thickness in parts of the Borsod Basin (Bohn-Havas and others, 1995; Radocz and others, 1987). In a study of the paleoenvironmental relations of the deposition of the coal sequence in the basin, Viczian and others (1997) observed that rock units underlying and interbedded with the coal seams consist predominantly of redeposited volcanogenic material derived from slightly older tuffaceous rocks. The coal seams contain a few bentonite layers derived from synchronous fallout of acid tuffs. Rocks above the coal-bearing part of the Salgotarjan, and rock. units overlying each of the coal seams, are terrigenous clastics (Viczian and others, 1997). Faulting and relatively simple folding are present throughout the basin, which may influence mining plans.
There are three major persistent coal seams in the Putnok mine area. All three have been mined at various times in the past, but only the middle seam, Bed II, has been mined recently.

\section{Resources and Recovery}

The coal resources of the Borsod Basin were estimated at about 1,147 million metric tons as of January 1, 1999 (Fodor and Gombar, 1999); of this total, some 61 million metric tons was estimated to be economically extractable.

In 1998, the Putnok mine, in which coal was recovered by use of standard longwall techniques, had the secondhighest specific mining costs (on a heat-value basis) of all the coal mines of Hungary. It and two other mines had specific mining costs that exceeded the estimated cost of coal imported from areas in eastern Europe, and all three mines are now closed. The Putnok mine area still had extractable resources of about 35 million tons of coal (Fodor and Gombar, 1999), but funding for improvements to reduce mining costs was apparently unavailable.

\section{Utilization}

In recent years, annual coal production of the Putnok mine was about 400,000 tons. Most was transported by railroad for use by AES Tisza Power Plant Ltd. to generate electricity and heat at the Tiszapalkonya powerplant, a 250-megawatt facility. 


\section{Coal Analyses}

Appendix I includes a description of the location, collection procedures, and samples collected from the Putnok mine. Sample analyses are listed in table 9 and Appendix II.

At the time of description and sampling (Appendix I), the mine-run product was composed of units 1 through 5 . Three of the units are coal (samples 2, 4, and 6, Appendix II) and two are noncoal partings. For purposes of calculation of seam-weighted averages, some assumptions were made about properties of the partings.

\section{Rank of Samples}

Table 7 shows the rank classification of each of the samples collected in the Putnok mine. Each of the samples represents a bench, or portion, of the coal sequence that was exposed in the mine at the time of sampling. The mine-run product from the sampled sequence includes the material represented by the three coal bench samples (Appendix I) plus the two interlayered tuffaceous claystone and sandstone partings that are present in the seam. The mine-run product included little or none of the claystone roof of the seam or the tuffaceous sandstone floor. All three of the coal samples show an apparent ASTM rank of lignite A and are only about 100 moist, mineral-matter-free Btu/lb below the rank of subbituminous $\mathrm{C}$. All three are ranked as Fenytelenkoszen in the Hungarian rank classification system. The calculated seam-weighted average that represents the mine-run product at the time of sampling indicates a high lignite A rank on the basis of a calculated moist, mineral-matter-free Btu/lb of nearly 8,300.

\section{Grade of Samples}

Table 8 lists the commonly used grade parameters for the Putnok samples. The coals have a high moisture content (more than 10 percent) according to the German system. The weighted-mean as-received moisture content of about 26 percent calculated for the sequence that could have been recovered at the time of sampling is similar to the moisture content expected for coals of this rank (table 1). The results of the equilibrium moisture determinations (table 8) verify the reported as-received moisture contents of the samples.
Following Wood and others (1983), two of the three Putnok coal samples are classified as having a medium ash yield and the other as having high ash yield. The ash yield calculated for the seam-weighted average is almost 19 percent, and the mine-run product is classified as having a high ash yield. Also following Wood and others (1983), the sulfur content is classified as high in two samples and medium in the third. The calculated total sulfur content for the seamweighted average is 2.8 percent, and the mine-run product is accordingly classified as having a medium sulfur content.

The organic sulfur content of the Putnok samples is 50 to 64 percent of the total sulfur content, in contrast to the Balinka and Armin samples in which more than 80 percent of the total sulfur in the coals is in the organic form.

\section{Other Properties}

\section{Ash-Fusion Temperatures}

The ash-fusion temperatures of the Putnok samples show a normal positive relation with the ash yield, in contrast to the Balinka mine samples.

\section{Hardgrove Grindability Index (HGI)}

The HGIs of the Putnok samples are lower than most of the other sample determinations and indicate that the coals may be tougher than the other sampled coals.

\section{Free-Swelling Index (FSI)}

All of the Putnok samples have an FSI of zero, indicating essentially no agglomerating properties.

\section{Apparent Specific Gravity (ASG)}

The apparent specific gravity of the Putnok samples ranges from 1.32 to 1.37 . Considering the ash yield of the samples, these determinations compare closely with the average specific gravity for lignitic (1.29) and subbituminous (1.30) coals used by Wood and others (1983).

Table 9. Proximate and ultimate analyses, calorific values, forms of sulfur, ash-fusion temperatures, Hardgrove grindability indices (HGI), free-swelling indices (FSI), and apparent specific gravities (ASG) in coal samples from the Putnok mine, Hungary.

[Analyses on as-received basis; values are in weight percent, except for calorific values (Btu/lb) and ash fusion temperatures ( $\left.{ }^{\circ} \mathrm{F}\right)$. V.M., volatile matter; Init, initial temperature; Soft, softening temperature; Hemi, hemispherical temperature; Fluid, fluid temperature]

\begin{tabular}{|c|c|c|c|c|c|c|c|c|c|c|}
\hline $\begin{array}{c}\text { Field } \\
\text { number }\end{array}$ & Moisture & Ash & V.M. & $\begin{array}{c}\text { Fixed } \\
\text { carbon }\end{array}$ & Hydrogen & Carbon & Nitrogen & Sulfur & Oxygen & $\begin{array}{c}\text { Calorific } \\
\text { value }\end{array}$ \\
\hline P6 & 25.81 & 18.31 & 29.18 & 26.70 & 5.78 & 37.95 & 0.64 & 3.26 & 34.06 & 6,577 \\
\hline $\mathrm{P} 4$ & 27.76 & 13.11 & 30.49 & 28.64 & 6.01 & 40.85 & 0.84 & 3.21 & 35.98 & 7,045 \\
\hline \multirow[t]{3}{*}{$\mathrm{P} 2$} & 27.55 & 15.00 & 30.10 & 27.35 & 6.05 & 39.64 & 0.79 & 2.25 & 36.27 & 6,926 \\
\hline & \multicolumn{3}{|c|}{ Forms of sulfur } & \multirow{2}{*}{ HGI } & \multirow{2}{*}{ FSI } & \multirow{2}{*}{ ASG } & \multicolumn{4}{|c|}{ Ash-fusion temperature } \\
\hline & Sulfate & Pyritic & Organic & & & & Init & Soft & Hemi & Fluid \\
\hline P6 & 0.05 & 1.11 & 2.10 & 40 & 0.0 & 1.35 & 2,290 & 2,330 & 2,410 & 2,460 \\
\hline P4 & 0.06 & 1.47 & 1.68 & 35 & 0.0 & 1.37 & 2,040 & 2,060 & 2,070 & 2,080 \\
\hline $\mathrm{P} 2$ & 0.05 & 1.08 & 1.12 & 41 & 0.0 & 1.32 & 2,190 & 2,250 & 2,300 & 2,350 \\
\hline
\end{tabular}




\section{Visonta Mine}

More than 25 percent of the coal produced in Hungary in 1999 came from the Visonta mine (fig. 3B). Out of a total of 8.6 million tons of coal produced from surface mines, 7.7 million tons was produced at two large surface mines (Visonta and Bukkabrany) in northern Hungary; of that total, the mine at Visonta produced 3.9 million tons.

\section{Description}

\section{Geology}

The coal-bearing rocks at the Visonta mine are in the Bukkalja Lignite Formation in the upper part of the Pannonian succession of middle Miocene to Pleistocene age. The

Pannonian succession unconformably overlies rocks as young as Miocene and, in turn, is overlain unconformably by sediments of Pleistocene age. It is assumed that the coal-bearing rocks in the Pannonian succession are of Pliocene age. However, some studies indicate that the coal-bearing part may be of Miocene age, at least in some areas (Teleki and others, 1994).

The area underlain by the Bukkalja Formation in northern Hungary is called the Eastern Lignite Area. In northwestern Hungary a similar coal-bearing rock unit called the Torony Lignite Formation is present in the Pannonian succession and underlies the Western Lignite Area. The Visonta mine is in the western part of the Eastern Lignite Area.

The Bukkalja Lignite Formation was deposited on a fluvial delta plain and is composed of gray, bluish-gray, and variegated claystone with sandstone intercalations, accompanied by lignitic coals in seams as thick as $15 \mathrm{~m}$ (Geological Institute of Hungary, 1997). The coal seams are lenticular and change thickness rapidly by pinching (wedging) or by splitting.

The bulk of the coal-bearing rock sequence in the Visonta mine area is composed of freshwater sediments with alternating layers of loose sands, clays, and lignite. The sequence is tilted 2-3 degrees to the southeast, away from the Matra Mountains, which are north and northwest from the mine area. Seven recoverable coal seams are recognized in the mine area. Seam thickness is variable, with no more than four seams thick enough to mine at any one place. The coal-bearing sequence thickens to the southeast, and individual seams are deeper and pinch or split in that direction (Laszlo Madai, Chief Geologist and Hydrologist, Visonta Mine, oral commun., 1997).

\section{Resources and Recovery}

The coal resources of the Visonta mine area are about 308 million tons, of which about 152 million tons are economically extractable. The Eastern Lignite Area has total coal resources of about 3,236 million tons and economically extractable reserves of about 1,621 million tons. The Eastern and Western Lignite Areas combined have coal resources of about 4,615 million tons and economically extractable reserves of about 2,151 million tons (Fodor and Gombar, 1999). The two lignite areas have about 49 percent of the total coal resources and about 84 percent of the economically extractable coal reserves of Hungary.

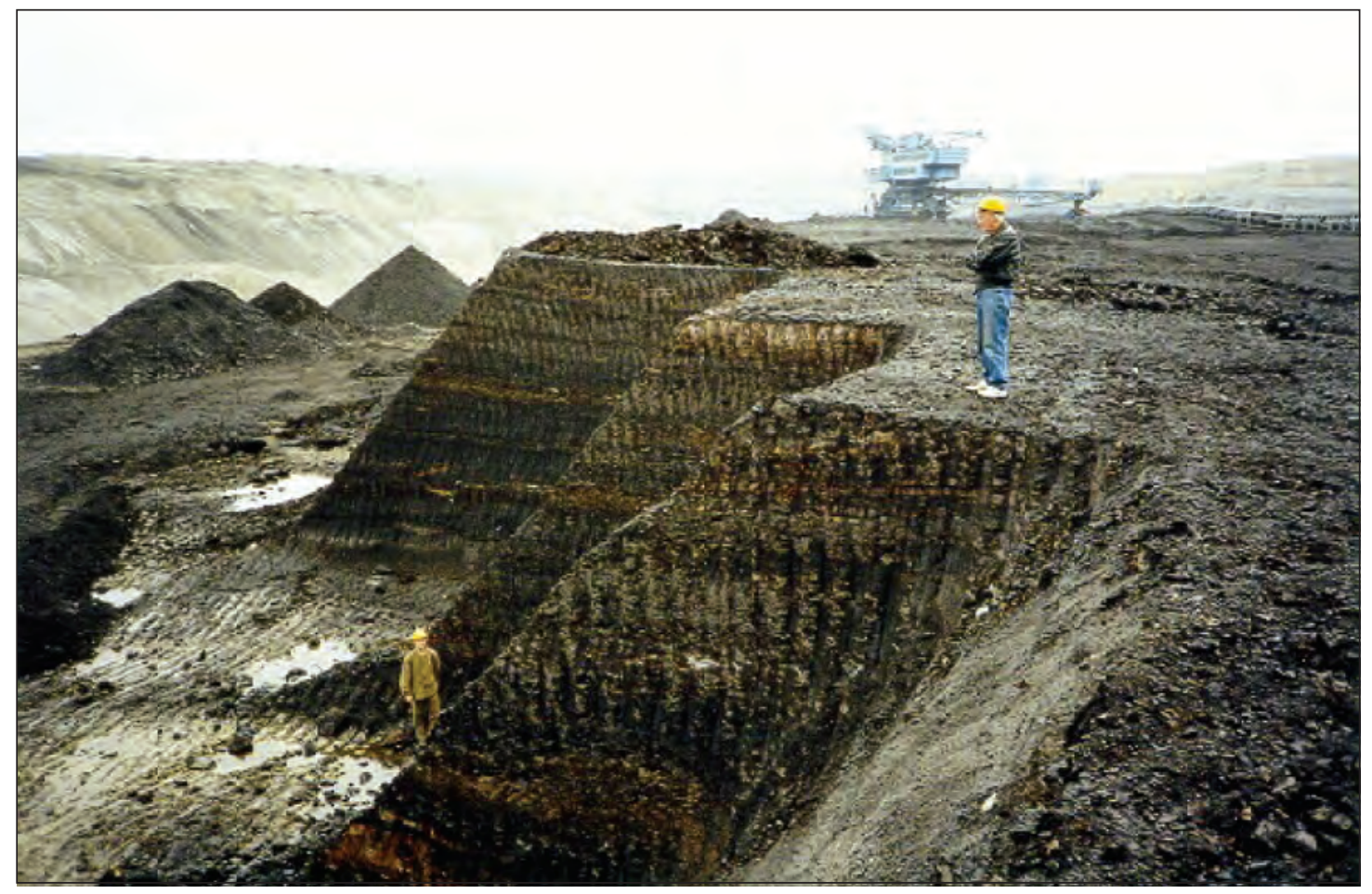

Figure 3. Visonta Mine, Eastern Lignite Area, Hungary. 
Coal is recovered at Visonta by use of standard Central European bucket-wheel and spreader technology. The open pit at Visonta is extensive, and most coal and overburden transport is by belt systems, supplemented by trucks as necessary.

\section{Utilization}

Coal produced from the Visonta Mine (and the

Bukkabrany Mine about $45 \mathrm{~km}$ to the east) is used to generate electricity at the Matra Power Plant a few kilometers away. Coal is transported to the plant by belt from Visonta and by train from Bukkabrany. Matra Power Plant Ltd. has a capacity of 812 megawatts, is the largest of eight coal-fired powerplants, and is the fourth largest of the 24 powerplants in Hungary (Kozlemenyei, 1999).

\section{Coal Analyses}

Appendix I includes a description of the location, collection procedures, and samples collected from the Visonta Mine. Individual sample analyses received from the analytical laboratory are in Appendix II, and table 10 shows these analyses on the as-received basis.

\section{Rank of Samples}

Table 7 shows the rank classification of the samples collected in the Visonta mine. Each of the samples represents a bench, or portion, of the coal sequence that was exposed in the mine at the time of sampling. The mine-run product from the sampled sequence includes the material represented by the 11 coal-bench samples and the coaly claystone parting near the middle of the seam (Appendix I).

All of the samples are classified as lignite B according to the ASTM system based on the moist, mineral-matter-free $\mathrm{Btu} / \mathrm{lb}$. The ASTM classificatiom is not designed to allow differentiation between lignitic coal and peat, which is the immediate predecessor. The Hungarian system does allow differentiation between coal and peat, but the available parameters do not completely coincide. When classified according to the ash-free heat value, 7 of the 12 samples are puhakoszen, the lowest class of brown coal, and the other 5 samples are peat. When classified according to ash-free moisture content, seven of the samples are peat.

The seven samples classified as brown coal have an average ash yield of 14 percent, and the five samples classed as peat have an average ash yield of 47 percent. However, rank classification of the individual samples is inhibited by the high

Table 10. Proximate and ultimate analyses, calorific values, forms of sulfur, ash-fusion temperatures, Hardgrove grindability indices (HGI), free-swelling indices (FSI), and apparent specific gravities (ASG) in coal samples from the Visonta mine, Hungary.

[Analyses on as-received basis; values are in weight percent, except for calorific values (Btu/lb) and ash-fusion temperatures $\left({ }^{\circ} \mathrm{F}\right)$. V.M., volatile matter; Init, initial temperature; Soft, softening temperature; Hemi, hemispherical temperature; Fluid, fluid temperature; ?, no data]

\begin{tabular}{|c|c|c|c|c|c|c|c|c|c|c|}
\hline $\begin{array}{c}\text { Field } \\
\text { number }\end{array}$ & Moisture & Ash & V.M. & $\begin{array}{l}\text { Fixed } \\
\text { carbon }\end{array}$ & Hydrogen & Carbon & Nitrogen & Sulfur & Oxygen & $\begin{array}{c}\text { Calorific } \\
\text { value }\end{array}$ \\
\hline V11 & 30.30 & 48.55 & 15.41 & 5.74 & 4.70 & 12.26 & 0.34 & 0.32 & 33.83 & 1,994 \\
\hline V9 & 32.49 & 49.58 & 14.10 & 3.83 & 4.88 & 9.49 & 0.19 & 0.80 & 35.06 & 1,679 \\
\hline V8 & 44.34 & 21.65 & 22.10 & 11.91 & 6.93 & 22.31 & 0.43 & 1.09 & 47.59 & 3,899 \\
\hline V7 & 35.23 & 52.06 & 10.68 & 2.03 & 4.99 & 6.36 & 0.15 & 0.29 & 36.15 & 1,117 \\
\hline V4 & 47.86 & 13.39 & 23.26 & 15.49 & 7.46 & 25.85 & 0.49 & 1.44 & 51.37 & 4,522 \\
\hline V3 & 39.68 & 39.93 & 15.00 & 5.39 & 5.78 & 12.19 & 0.30 & 0.47 & 41.33 & 2,109 \\
\hline $\mathrm{V} 2$ & 48.40 & 9.42 & 25.64 & 16.54 & 7.63 & 27.44 & 0.42 & 2.10 & 52.99 & 4,739 \\
\hline \multirow[t]{2}{*}{ V1 } & 48.17 & 15.17 & 22.55 & 14.11 & 7.42 & 24.36 & 0.39 & 1.35 & 51.31 & 4,239 \\
\hline & \multicolumn{3}{|c|}{ Forms of sulfur } & HGI & FSI & ASG & \multicolumn{4}{|c|}{ Ash-fusion temperature } \\
\hline V9 & 0.12 & 0.45 & 0.23 & 45 & 0.5 & 1.43 & 2,450 & 2,540 & 2,650 & 2,730 \\
\hline V8 & 0.09 & 0.43 & 0.57 & 39 & 0.5 & 1.16 & 2,120 & 2,150 & 2,200 & 2,280 \\
\hline V7 & 0.03 & 0.21 & 0.05 & 43 & 0.5 & 1.54 & 2,430 & 2,480 & 2,510 & 2,530 \\
\hline V6 & 0.14 & 0.91 & 0.73 & $?$ & 0.5 & 1.06 & 2,080 & 2,120 & 2,140 & 2,160 \\
\hline V5 & 0.04 & 0.21 & 0.21 & $?$ & 0.5 & 1.41 & 2,380 & 2,400 & 2,450 & 2,580 \\
\hline V4 & 0.09 & 0.57 & 0.78 & $?$ & 0.5 & 1.02 & 2,110 & 2,140 & 2,150 & 2,160 \\
\hline $\mathrm{V} 3$ & 0.03 & 0.19 & 0.25 & $?$ & 0.5 & 1.20 & 2,390 & 2,430 & 2,540 & 2,690 \\
\hline $\mathrm{V} 2$ & 0.20 & 1.06 & 0.84 & $?$ & 0.5 & 0.97 & 2,170 & 2,180 & 2,190 & 2,210 \\
\hline V1 & 0.08 & 0.71 & 0.56 & $?$ & 0.5 & 1.11 & 2,140 & 2,170 & 2,210 & 2,270 \\
\hline
\end{tabular}


ash contents of almost one-half of the bench samples. The seam-weighted average heat value of the sampled sequence (table 1) is 4,000 Btu/lb with 20.7 percent ash, indicating an ash-free heat value of almost 5,050 Btu/lb. The sampled sequence at Visonta should be classified as the lowest class of brown coal, puhakoszen. This conclusion is further affirmed by the compact, coherent nature of the material that is being mined (see fig. 2).

\section{Grade of Samples}

Table 8 lists the commonly used grade parameters for the Visonta samples. The samples have a high moisture content (more than 10 percent) according to the German system. The weighted-mean as-received moisture content of almost 44 percent calculated for the sequence being mined at the time of sampling leads to the conclusion that the sequence should be classed as brown coal. The equilibrium moisture determinations (table 8) verify the reported as-received moisture contents of the samples.

Seven of the Visonta samples would be classified as having medium and high ash yield by Wood and others (1983). The other five bench samples would be classed as very high ash yield. The ash yield calculated for the seam-weighted average is almost 21 percent, and the mine-run product would be classified as having a high ash yield.

Based on Wood and others (1983), six of the Visonta samples would be classified as having medium total sulfur content and the other six as low sulfur content. The organic sulfur content has a strong negative linear relation with the ash yield (correlation coefficient of -0.88 ), and the same relation is reflected by the five samples having very high ash yields and low sulfur contents. The calculated total sulfur content for the seam-weighted average is 1.2 percent, and the minerun product would be classified as having a medium sulfur content.

\section{Other Properties}

\section{Ash-Fusion Temperatures}

The ash-fusion temperatures of the Visonta samples show a normal positive relation with the ash yield (correlation coefficients of +0.69 to +0.80 ) and also reflect the difference in behavior between samples with lower ash yields in contrast to those samples with very high ash yields. For example, the former group of seven has a fluidizing temperature range of 2,160 to 2,490 and the latter group of five has a fluidizing temperature range of 2,530 to 2,730 .

\section{Hardgrove Grindability Index (HGI)}

Hardgrove Grindability was determined for only four of the Visonta samples. The determined HGIs indicate that the coals are tough rather than brittle.
Free-Swelling Index (FSI)

Most of the Visonta samples have an FSI of 0.5. This property should have little or no effect on standard methods of utilization.

\section{Apparent Specific Gravity (ASG)}

The apparent specific gravity of the Visonta samples ranges from 0.97 to 1.54 , with a fairly strong positive linear relation between the as-received ash yield and the apparent specific gravity (correlation coefficient of +0.79 ). Seven of the 12 samples have an apparent specific gravity that is less than the average specific gravity for lignitic coals (1.29) suggested by Wood and others (1983).

\section{Summary}

Coal and coaly materials have been reported at more than 250 localities in Hungary, in rocks ranging in age from Carboniferous to Pliocene(?). The coals mined in recent years are of Early Jurassic to Miocene and (or) Pliocene age and have provided as much as 25 percent of Hungary's total domestic energy production.

Representative samples from five mines were collected and analyzed to provide basic data on the physical and chemical properties of coals of different ages and geologic histories. These mines-Zoback (Jurassic), Armin (Cretaceous), Balinka (Eocene), Putnok (Miocene), and Visonta (Pliocene[?])—produced about one-third of the coal mined in Hungary at the time the samples were collected. All samples were collected from fresh or recently exposed coal faces and were analyzed according to standard practices of the U.S. Geological Survey.

Coals from the five mines exhibit distinct differences in composition, reflecting (1) age of the coal-bearing rocks, (2) depositional setting, (3) relative amounts and types of organic and inorganic materials in the original sediments, and (4) the timing and magnitude of sedimentary and tectonic events.

Coal rank was determined using the system of the American Society for Testing and Materials (ASTM), with comparisons to a Hungarian system that is similar to a German system commonly used in Central Europe. The results showed coal rank in the ASTM system to range from high volatile A bituminous (Lower Jurassic coals in the Zoback mine) to lignite B (Pliocene[?]) coals in the Visonta mine) in general accordance with the decreasing age of the coal-bearing rocks.

Four of the five coals studied were classed as having high moisture contents (more than 10 percent), the results again showing a progressive difference with age (Zoback coals with 3.4 percent and Visonta coals with 43.8 percent). Four coals were shown to have high ash contents (more than 15 percent) 
and one (Balinka) to have a medium ash content ( 8 to 15 percent); but in this case, differences do not reflect age but the relative amount of inorganic material.

The total amount and the form of sulfur in coals strongly affect their preparation for utilization and efforts to mitigate potential environmental and health problems. Two of the coals studied (Zoback and Balinka) were classed as having high sulfur contents ( 3 percent or more) and the other three as medium sulfur (more than 1 percent to less than 3 percent). The three different forms of sulfur-sulfate, pyritic, and organic - that compose the total sulfur content were also determined. In the five coals studied, sulfate sulfur ranged from 0.02 to 0.09 percent, pyritic sulfur from 0.28 to 2.82 percent, and organic sulfur from 0.58 to 3.55 percent.

General characteristics of coals in individual mines are summarized as follows:

Zoback mine. With the exception of its high sulfur content, the high volatile A bituminous coal is considered to be of relatively high quality because of its high heat value (mean of 8,650 Btu/lb) and low moisture content (mean of 3.4 percent). However, the complex geologic conditions affect the economics of mining, and the long-term future of coal resources in the area may lie with the reportedly high gas content of the coals.

Armin mine. Analytical results indicate that the coals can be classed as having high moisture, high ash, and medium sulfur contents. The indicated rank of lignite A may be low because of its calcium carbonate content, which constitutes much of the inorganic material of the coal sequence. A large part of the total sulfur content is closely associated with the organic portion of the coaly material.

Balinka mine. The subbituminous $\mathrm{C}$ coals are high in moisture, medium in ash, and high in sulfur contents. Most of the sulfur (about 87 percent) is in the form of organic sulfur and is difficult to remove by ordinary coal-cleaning processes. In contrast to most Hungarian coals, the ash-fusion temperatures and ash yield do not seem to be directly related.

Putnok mine. Coals are of lignite A rank, and the minerun product has high moisture, high ash, and medium sulfur contents. Nearly equal amounts of pyritic and organic sulfur are present.

Visonta mine. All samples are classed as lignite B in the ASTM system, whereas nearly half — those with ash yields of 40 percent or more-are classed as peat in the HungarianGerman system. In general, however, the compact, coherent nature of the material indicates that it more nearly resembles brown coal and (or) lignite B. The coal has high moisture, high ash, and medium sulfur contents. The fact that coal similar to that mined at Visonta constitutes about 84 percent of the known economically recoverable coal reserves of Hungary can be of major importance in the nation's energy future.

\section{References}

American Society for Testing and Materials (ASTM), 1999, Annual book of ASTM standards, volume 05.05, Gaseous fuels-Coal and coke: American Society for Testing and Materials, West Conshohocken, Pa., 583 p.

Attanasi, E.D., and Root, David, 1999, Coal-fired power generation, new air quality regulations and future United States coal production: Environmental Geosciences, v. 6, no. 3, p. 139-145.

Bohn-Havas, M., Nagy, E., Radocz, Gyula, Rakosi, I., and Szego, E., 1995, A paleoenvironmental reconstruction of the early Miocene coal-bearing sequence in the Borsod Basin, Hungary: Xth RCMNS Congress, Bucharest, Romania, Abstracts 3, p. 217-219.

Brown, R.L., and Hiorns, F.J., 1963, Mechanical properties, in Lowry, H.H., ed., Chemistry of coal utilization, supplementary volume: New York, John Wiley \& Sons, Inc., p. 119-149.

Callcott, T.G. and Smith, G.B., 1981, Mechanical properties of coal, in Elliott, M.A., ed., Chemistry of coal utilization, second supplementary volume: New York, John Wiley and Sons, p. 285-316.

Csaszar, Geza, ed., 1997, Basic lithostratigraphic units of Hungary: Submissions of the Stratigraphic Commission of Hungary, published by the Geological Institute of Hungary.

Elston, D.P., Lantos, M., and Hamor, T., in Teleki, P.G., Mattick, R.E., and Kokai, J., eds., 1994, Basin analysis in petroleum exploration, a case study from the Bekes basin, Hungary: Dordrecht, The Netherlands, Kluwer Academic Publishers, p. 111-142.

Fodor, Bela, and Gombar, Gizella, 1999, Hungarian coal resources review: Coal Resources Evaluation-Workshop, October 1999, Denver, Colo.

Fodor, Bela, Gombar, Gizella, and Sebestyen, Istvan, 1998, Field trips in Hungary-Coal mines and occurrences: Hungarian Geological Survey, 69 p.

Geological Institute of Hungary, 1997, Basic lithostratigraphic units of Hungary (chart and short descriptions): Geological Institute of Hungary, Budapest, Hungary.

Gluskoter, H.J., Shimp, N.F., and Ruch, R.R., 1981, Coal analyses, trace elements and mineral matter, in Elliott, M.A., ed., Chemistry of coal utilization, second supplementary volume: New York, John Wiley and Sons, p. 369-424. 
Goczan, F., Siegal-Farkas, A., Mora-Czabalay, L., Rimanoczy, A., Viczian, I., Rakosi, L., Csalagovits, I., and Partenyi, Z., 1986, Ajka Coal Formation, biostratigraphy and geohistory: Acta Geologia Hungarica, v. 29, nos. 3-4, Akademiai Kiado, Budapest, p. 221-231.

Haas, J., Jocha-Edelenyi, E., and Csaszar, G., 1992, Upper Cretaceous coal deposits in Hungary, in McCabe, P.J., and Parrish, J.T., eds., Controls on the distribution and quality of Cretaceous coals: Geological Society of America, Boulder, Colo., Special Paper 267, p. 245-262.

Hetenyi, R., 1964, Detailed geological study of Mecsek Mountain: Annual Report of the Hungarian Geological Institute, 1964, p. 15-20.

Hungarian Geological Institute, 1969, Annals of the Hungarian Geological Institute-Mecsek Mountain: Budapest, v. LI. 2.

Kozlemenyei, 1999, Statistical data-1998: A Magyar Villamos Muvek Rt. (Hungarian Power Companies Ltd.), v. 36, no. 3, June 1999, Budapest, Hungary.

Landis, E.R., Rohrbacher, T.J., Barker, C.E., Fodor, Bela, and Gombar, Gizella, 2001, Coalbed gas in the Mecsek Basin, Hungary: Programme-TSOP/ICCP session, 15th August 2001, 53rd ICCP meeting, 12th-19th August, Copenhagen, Denmark, unpaginated.

Landis, E.R., Rohrbacher, T.J., Barker, C.E., Fodor, Bela, and Gombar, Gizella, 2002a, Coalbed gas in HungaryA preliminary report: U.S. Geological Survey Open-File Report 2001-473, version 1.0, CD-ROM.

Landis, E.R., Rohrbacher, T.J., Barker, C.E., Fodor, Bela, and Gombar, Gizella, 2002b, Coalbed gas in the Mecsek Basin, Hungary, in Coalbed Methane Workshop in Hungary, September 23, 25-26, 2002-Presentations: U.S. Geological Survey, Hungarian Geological Survey, and United States-Hungarian Science and Technology Joint Fund (CD-ROM prepared by Hungarian Geological Survey, Budapest).

Landis, E.R., Rohrbacher, T.J., Barker, C.E., Fodor, Bela, and Gombar, Gizella, 2003a, Coalbed gas in the Mecsek Basin, Hungary: International Journal of Coal Geology, v. 54/1-2, p. 41-55.
Landis, E.R., Rohrbacher, T.J., Barker, C.E., Fodor, Bela, and Gombar, Gizella, 2004b, Coal-bed gas in Hungary, in Pierce, B.S., Dennen, K.O., and Finkelman, R.B., Coal quality: Global Priorities International Conference, U.S. Geological Survey-Reston, Virginia, September 2426, 2001: U.S. Geological Survey Circular 1272, CD-ROM.

Landis, E.R., Rohrbacher, T.J., Barker, C.E., Gluskoter, H.J., Fodor, Bela, and Gombar, Gizella, 2003b, Coalbed methane in Hungary-Workshop and Field trips, September 14October 1, 2002: U.S. Geological Survey Open File Report 2003-086, CD-ROM.

Landis, E.R., Rohrbacher, T.J., Gluskoter, H.J., Fodor, Bela, Gombar, Gizella, and Sebestyen, Istvan, 1999, Coals of Hungary: Sixteenth Annual International Pittsburgh Coal Conference, October 1999, Proceedings Volume.

Landis, E.R., Rohrbacher, T.J., Gluskoter, H.J., Fodor, Bela, Gombar, Gizella, and Sebestyen, Istvan, 2000, Quality of selected coals of Hungary: Proceedings, 25th International Technical Conference on Coal Utilization and Fuel Systems, March 2000, Clearwater, Fla., p. 369-373.

Landis, E.R., Rohrbacher, T.J., Gluskoter, H.J, Fodor, Bela, Gombar, Gizella, and Sebestyen, Istvan, 2004a, Quality of selected Hungarian coals, in Pierce, B.S., Dennen, K.O., and Finkelman, R.B., Coal Quality: Global Priorities International Conference, U.S. Geological Survey-Reston, Virginia, September 24-26, 2001: U.S. Geological Survey Circular 1272, CD-ROM.

Radocz, Gyula, 1982, Coal deposits of Hungary: Annual report of the Hungarian Geological Institute, 1983, p. 63-74.

Radocz, Gyula, Bohn-Havas, M., and Szokolai, Gyula., 1987, Neogene brown coal deposits in Hungary: Annals of the Hungarian Geological Institute, v. LXX, VIIIth RCMNS Congress, Budapest, 1985.

Rees, O.W., 1966, Chemistry, uses, and limitations of coal analyses: Illinois State Geological Survey, Report of Investigation $220,55 \mathrm{p}$.

Reid, W.T., 1981, Coal ash-Its effect on combustion systems, in Elliott, M.A., ed., Chemistry of coal utilization, second supplementary volume: New York, John Wiley and Sons, p. 1389-1445.

Selvig, W.A., and Gibson, F.H., 1945, Calorific value of coal, in Lowry, H.H., Chemistry of coal utilization, volume 1: New York, John Wiley, p. 132- 144. 
Speight, J.G., 1983, The chemistry and technology of coal: New York and Basel, Marcel Dekker, Inc., 528 p.

Taylor, G.H., Teichmuller, M., Davis, A., Diessel, C.F.K., Littke, R., and Robert, P., 1998, Organic petrology: Berlin, Gebruder Borntraeger, 704 p.

Teichmuller, M., and Teichmuller, R., 1982, The geological basis of coal formation, in Stach, E., Mackowsky, M-Th., Teichmuller, M., Taylor, G.H., Chandra, D., and Teichmuller, R., 1982, Stach's textbook of coal petrology, 3d edition: Gebruder Borntraeger, Berlin, p. $5-86$.

Teleki, P.G., Mattick, R.E., and Kokai, Janos, eds., 1994, Basin analysis in petroleum exploration, a case study from the Bekes basin, Hungary: Dordrecht, The Netherlands, Kluwer Academic Publishers, 330 p.
Tomschey, O., 1995, Unusual enrichment of U, Mo and V in an Upper Cretaceous coal seam in Hungary, in Whateley, M.G.K., and Spears, D.A.,eds., European coal geology: Geological Society (London), Special Publication no. 82, p. 299-305.

Tschamler, H., and De Ruiter, E., 1963, Physical properties of coal, in Lowry, H.H., ed., Chemistry of coal utilization, Supplementary Volume: New York, John Wiley \& Sons, Inc., p. 35-118.

Viczian, I., Barna, Zs., Foldvari, M., 1997, Mineralogy of barren rocks in Lower Miocene brown coal deposits of the Borsod Basin (North Hungary): Foldtani Kozlony 127/1-2, p. 127-144, Budapest, 1997.

Wood, G.H., Jr., Kehn, T.M., Carter, M.D., and Culbertson, W.C., 1983, Coal resource classification system of the U.S. Geological Survey: U.S. Geological Survey Circular 891, 65 p. 
This page left blank intentionally. 


\section{Appendixes}


This page left blank intentionally. 


\section{Appendix I. Description of Samples}

This Appendix contains the edited field notes that describe the sampling activities at each of the five mines where samples were collected in Hungary in October 1998.

Within the sampling and related activities, specific tasks rotated as necessary, but the authors all share collective responsibility for sample selection, description, and collection.

Information peripheral to the sampling itself was graciously supplied by the personnel of the visited mines. Their assistance is very much appreciated.

\section{Zobak Mine}

The Zobak mine north of the city of Pecs, in southwestern Hungary, was visited October 14, 1998. Our host was Miklos Baricz-Chief Geologist.

The coals in the area are of Jurassic age and are the oldest coals mined in the country. The bed that was sampled is recognized as Bed No. XII. The coal and rock sequence that was measured, described, and sampled was exposed on a longwall face on III Level, $2 \mathrm{~d}$ Crossdrift. The sampling point is about $1,800 \mathrm{~m} \mathrm{~S} ., 20^{\circ} \mathrm{E}$. from the main shaft of the mine. The main shaft is located at about lat $46^{\circ} 11^{\prime} 27 " \mathrm{~N}$., long $18^{\circ} 17^{\prime} 22^{\prime \prime E}$., and is $650 \mathrm{~m}$ deep. The sampling point is near this depth.

Bed No. XII is inclined as much as $15^{\circ}$ nearby but dips only a few degrees at the sampling point.

Base of measured section was sampled upward.

\section{Unit - Thickness - Description}

Floor is slickensided, dark gray claystone, $0.5+\mathrm{m}$ thick.

1-34 cm-Claystone, dark gray and interbedded coal, fractured, slickensided, bright, some fusain.

\section{Sample \#1}

2-8 cm-Coaly claystone, dark gray, shaley.

3-7 cm-Coal, with pyrite lens $1 \mathrm{~cm}$ thick and $5 \mathrm{~cm}$ long.

4-9 cm-Coal and dark gray claystone interbedded in lenses

$1 \mathrm{~cm}$ to $2 \mathrm{~cm}$ thick and less than $10 \mathrm{~cm}$ long.

Sample \#3 includes units 2, 3, and 4.

$5-31 \mathrm{~cm}-$ Coal, fractured, very bright, banded up to $2 \mathrm{~cm}$ thick, no noncoal portions. Few thin films of pyrite on cleat. Some face and butt cleat observable.

6-18 cm-Coal, very bright, no banding. Some calcite or kaolinite.
Sample \#2 includes units 5 and 6.

$7-6 \mathrm{~cm}-$ Gouge along slippage fault which is at about $10^{\circ}$ angle to bedding. Sample consists of dust to $0.10-\mathrm{cm}$ coal pieces.

8-30 cm-Coal, fractured but more consolidated than other coal units, very bright, banded with obvious vitrain, kaolinite or calcite on cleats, scattered fusain bodies as much as $0.5 \mathrm{~cm}$ long and thick.

Sample \#4 includes units 7 and 8.

9-16 cm-Claystone, coaly, medium gray, slickensided and fractured but more compact than the coal units. As much as 10 percent of unit is coal lenses up to $0.5 \mathrm{~cm}$ thick.

Sample \#5

10-22 cm-Coal, similar to unit 8 in consolidation, bright but no obvious banding, fractured and slickensided.

Sample \#6

Roof-Coal similar to Unit 10,10+ cm thick, not sampled.

\section{Armin Mine}

The Armin Mine, one of two adjacent mines near Ajka, Hungary, was visited on October 16, 1998.

Our hosts were Istvan Kasa, Chief Geologist; Attila Nemeth, Geologist; and Jozsef Bognar, Chief Engineer.

The coal-bearing rocks in the area are of Cretaceous age, and the units measured and sampled were the upper and lower parts of Bed No. 4. Sampling was conducted in two adjacent short development drifts located near the operating longwall face. The drifts allowed examination and sampling of the otherwise mostly inaccessible longwall face that was being mined.

The measurement and sampling point was about $1,300 \mathrm{~m}$ S., $85^{\circ} \mathrm{E}$. from the mine portal. The portal is at an elevation of $265 \mathrm{~m}$, and the sampling point about $195 \mathrm{~m}$ above sea level. The maximum overburden thickness at the mine is $416 \mathrm{~m}$. The mine office near the portal is located at about lat $47^{\circ} 05^{\prime} 21^{\prime \prime} \mathrm{N}$., long $17^{\circ} 34^{\prime} 54$ "E.

The measured section started at the end of Drift 454/B.

\section{Unit - Thickness - Description}

The roof is tan marl containing abundant fossil fragments, $10+\mathrm{cm}$ thick.

1-10 cm-Coal, marly, dark brown, many fossil fragments, coal as laminae throughout. 


\section{Sample \#3}

2-6 cm-Marl, light tan, some fossil fragments but not as abundant as in beds above, unit ranges from 2 to $8 \mathrm{~cm}$ thick across exposed face. Unit not sampled.

3-15 cm-Coal, marly, banded $<1 \mathrm{~mm}$ thick, with coaly marl as lenses.

\section{Sample \#1}

4-11 cm-Marl, coaly, mostly light tan, similar to Unit 2, with coal as scattered laminae, gastropods as much as $2 \mathrm{~cm}$ in diameter, unit ranges from 9 to $14 \mathrm{~cm}$ in thickness across exposed face.

\section{Sample \#2}

$5-20 \mathrm{~cm}-$ Coal, marly, with marl in stringers $<3 \mathrm{~mm}$ thick, some gastropods in the marl stringers.

$6-22 \mathrm{~cm}$-Coal, upper $15 \mathrm{~cm}$ are bright and banded $<1 \mathrm{~mm}$ thick, rest is marly with fossil frags.

Sample \#4-Includes both units 5 and 6 .

7-27 cm-Coal, marly, and coaly marl, grainy, brown, persistent unit indicated by massive texture and color.

\section{Sample \#5}

$8-13 \mathrm{~cm}-$ Coal, slightly clayey, face cleat and butt cleat developed, rare marl stringers.

\section{Sample \#6}

9-9 cm-Marl, tan, slightly coaly in lenses up to $1.5 \mathrm{~cm}$ thick. Few fossils, but not as abundant as in other marl units. Unit not sampled.

10-9 cm-Marl, coaly, dark brown, few fossils. Unit not sampled.

11-19 cm-Coal, bright, some banding, face cleat, conchoidal fracture.

\section{Sample \#7}

$12-15 \mathrm{~cm}-$ Coal, bright, no cleat, some marl stringers with abundant fossils.

\section{Sample \#8}

13-25 cm-Marl, slightly coaly, brown, finely bedded, abundant fossils. Unit not sampled.

Move to end of Drift 454/A.

14-77 cm-Coal, marly, and coal; the upper $28 \mathrm{~cm}$ and lower $37 \mathrm{~cm}$ of the unit are bright and banded with a few marl lenses. The middle $12 \mathrm{~cm}$ of the unit is light tan marl.
Sample \#9-Does not include the 12-cm marl near the middle of the unit.

15-18 cm-Marl, slightly coaly, light to medium brown. Unit not sampled.

16-28 cm-Coal, bright, banded, conchoidal fracture.

$17-21 \mathrm{~cm}-$ Marl, coaly, light to medium brown. Unit not sampled.

18-17 cm-Coal, bright, banded, conchoidal fracture.

Sample \#10-Includes only units 16 and 18. Does not include unit 17.

19-25 cm-Marl, coaly, light to dark brown, coal lenses as much as $4 \mathrm{~cm}$ thick.

20-41 cm - Coal, slightly marly, bright, banded, conchoidal fracture. Unit not sampled.

\section{Sample \#11}

21-5 cm-Marl, slightly coaly, light brown. Unit not sampled. 22-14 cm-Coal, bright, banded.

23-4 cm-Marl, slightly coaly, light brown. Unit not sampled. 24-39 cm-Coal, bright, banded, some cleat development.

Sample \#12-Includes only units 22 and 24. Does not include units 21 and 23.

25-60 cm-Marl, coaly, light brown.

Base of measured section.

\section{Balinka Mine}

The Balinka mine near the town of Balinka, in westerncentral Hungary, was visited October 15, 1998. Our host was Tibor Molnar, Chief Geologist.

The Balinka mine recovers coal from rocks of Eocene age that are overlain by Oligocene-Miocene clastics and underlain by rocks of Mesozoic age.

Measured section and samples are from a 50-m longwall face that is recovering an odd-shaped pillar between areas previously mined out. Location is about $500 \mathrm{~m}$ below the surface about 1 kilometer N., $50^{\circ} \mathrm{W}$. from Shaft II.

All samples are from the lower bench of Bed 1 .

At the main shaft, No. I, the surface elevation is $181 \mathrm{~m}$ and the location is about lat $47^{\circ} 19^{\prime} 04^{\prime \prime} \mathrm{N}$., long $18^{\circ} 09^{\prime} 03^{\prime \prime} \mathrm{E}$. Shaft II is about $4.5 \mathrm{~km} \mathrm{~N}$., $48^{\circ}$ E. of Shaft I.

Top of measured section (sampled downwards).

\section{Unit - Thickness - Description}

Coal overlying, description and thickness not possible.

1A-26 cm-Marl, light gray, fossil hash of broken, soft, nacreous shell material. 
1B-46 cm-Marl, coaly, massive, light to medium gray, coarse granules of fossil shell material obvious, scattered coal laminae.

Sample \#1 includes only unit 1B.

$2-59 \mathrm{~cm}-$ Coal, very bright, finely banded, well-developed face cleat at $70^{\circ}$ from vertical; the upper surface may be slippage and there is a poorly defined slippage(?) area near base.

\section{Sample \#2}

3-20 cm-Coal, massive, conchoidal surfaces, bright, very finely banded.

\section{Sample \#3}

$4-32 \mathrm{~cm}-$ Coal, bedding or banding as much as $0.5 \mathrm{~cm}$ thick, strong face cleat.

\section{Sample \#4}

5-72 cm-Coal, shaley, massive, dull.

\section{Sample \#5}

6-22 cm-Coal, clayey, massive to thinly bedded.

\section{Sample \#6}

Floor is $10+\mathrm{cm}$ claystone, reddish-brown, with coaly laminae $<1 \mathrm{~mm}$ thick.

\section{Putnok Mine}

The Putnok Mine, at Kirald, Hungary, was visited on October 20, 1998. Our hosts were Gusztav Sztermen, Technical Director, and Ferenc Biro, Geologist.

The coal-bearing rocks are of Miocene age. There are three persistent coal beds but only Bed II has been mined during the last 10 years. The other two were also mined earlier.

The measured section and sampled coal sequence was exposed in a development drift at the west end of an east-west longwall face in the eastern part of the mine. The sampling point is $2,380 \mathrm{~m} \mathrm{~S}$., $75^{\circ} \mathrm{E}$. from the shaft entrance near the mine office. The mine office is located at about lat $48^{\circ} 15^{\prime} 00^{\prime \prime} \mathrm{N}$., long $20^{\circ} 23^{\prime} 30^{\prime \prime} \mathrm{E}$.

The mine has a vertical shaft $250 \mathrm{~m}$ deep for men, equipment, and ventilation. Mined coal exits on a belt system through an inclined shaft. The sampling point is slightly above the base of the shaft.

Measured section, sampled upward.

\section{Unit - Thickness - Description}

Floor-Tuffaceous very fine grained, light gray sandstone.
Sample\#1, for lithology, not analyzed.

1-84 cm-Coal, brownish-black, dull but has faint banding 1 to $2 \mathrm{~mm}$ thick.

\section{Sample \#2}

2-4 cm-Sandstone, tuffaceous, light tan, with some coaly laminae $<1 \mathrm{~mm}$ thick.

Sample \#3- for lithology, not analyzed.

3-45 cm-Coal, brownish-black, bright and banded in part, dull otherwise, some conchoidal fracture.

Sample \#4

4-5 cm-Claystone, tuffaceous(?), light tan, very lenticular.

Sample \#5, for lithology, not analyzed.

5-91 cm-Coal, brownish-black, bright, some faint banding, conchoidal fracture, persistent 5-mm-thick tuffaceous claystone about $41 \mathrm{~cm}$ below top (included in sample).

Sample \#6

6-2 cm+-Claystone, dark gray, slickensided.

Roof.

\section{Visonta Mine}

The Visonta EAST II Mine, near Visonta, Hungary, was visited on October 19, 1998.

Our hosts were Laszlo Madai, Chief Geologist and Hydrologist, and Laszlo Kolozsvari, Chief of the Sampling Group.

The bed that was freshly exposed and sampled is Bed 0 (zero) of the multibed sequence that is mined. Bed 0 is the thickest and most persistent of the beds and was the source of most of the coal produced at the time of our visit. The mine routinely establishes sampling points every $50 \mathrm{~m}$, and our measured section and samples were near their Sampling Point \#5.

The sampling point is about $1,820 \mathrm{~m} \mathrm{~S} ., 10^{\circ} \mathrm{W}$. from the entrance to the pit, whose point location is about lat $47^{\circ} 46^{\prime} 19^{\prime \prime} \mathrm{N}$. , long $20^{\circ} 08^{\prime} 24^{\prime \prime} \mathrm{E}$.

Base of measured section, sampled upward.

\section{Unit - Thickness - Description}

Floor is $10+\mathrm{cm}$ light yellowish-gray bentonitic(?) silty claystone.

1-100 cm-Coal, mostly dark brown with about 10 percent light tan woody parts 0.5 to $10 \mathrm{~cm}$ thick. There is $5 \mathrm{~cm}$ of dark grey claystone $50 \mathrm{~cm}$ above base of unit. 
Sample \#1-Sample includes the $5 \mathrm{~cm}$ claystone.

2-44 cm-Coal, dark brown, 15-20 percent woody parts.

\section{Sample \#2}

3-17 cm-Coal, clayey, dark brown, bentonitic(?), slightly slickensided, woody parts smaller than in Units 1 and 2.

\section{Sample \#3}

4-64 cm-Coal, dark brown, 15-20 percent woody parts, with most in lower part of unit.

Sample \#4

5-16 cm-Coal, clayey, dark brown, similar to unit 3 .

Sample \#5

6-59 cm-Coal, dark brown, 25 percent wood with most near top, some woody parts $10-15 \mathrm{~cm}$ thick.

\section{Sample \#6}

7-60 cm-Claystone, coaly, dark brown, coal lenses 0.5 to $2 \mathrm{~cm}$ thick and $2-10 \mathrm{~cm}$ long.
Sample \#7

8-81 cm-Coal, dark brown, 25-30 percent woody parts in pieces $3 \mathrm{~mm}$ to $1.5 \mathrm{~cm}$ thick.

Sample \#8

9-14 cm-Coal, clayey, dark brown, slickensided, bentonitic(?). Only a few wood pieces.

Sample \#9

10-70 $\mathrm{cm}-$ Coal, dark brown, $25-30$ percent woody parts.

Sample \#10

11-11 cm-Coal, clayey, dark brown, $<10$ percent woody parts in pieces $2 \mathrm{~mm}$ to $5 \mathrm{~mm}$ thick and $2-5 \mathrm{~cm}$ long, slickensided, bentonitic(?).

Sample \#11

12-80+ $\mathrm{cm}-$ Coal, dark brown, $30-35$ percent woody parts with preserved logs near top.

Upper $10 \mathrm{~cm}$ may be slightly weathered.

Sample \#12

Top of exposure, top of bench and near top of Bed O. 


\section{Appendix II. Coal Analyses}

This Appendix contains the reported coal analyses, according to individual sample, performed by Geochemical Testing pursuant to the provisions of a contract between them and the U.S. Geological Survey. Geochemical Testing is a division of Energy Center, Inc., located in Somerset, Pa., USA.

Analyses were performed according to applicable standards and methods of the American Society for Testing and Materials.

The sample analyses are presented herein in the order in which each is described in Appendix I. 
2005 N Center Ave Somerset PA 15501

$814 / 443-1671$

$814 / 445-6666$

FAX: 814/445-6729

ZOAL ANALYSIS REPORT

Client: US GEOLOGICAI SURVEY-CO (MCHG)

Sampled by: E.R. Iandis

Sampling Date: 01/26/1999

Analyzed on: 02/09/1999

Description: Zobak Mine zI

IAB NO. 99-013048

Air Dry Loss............ 2. 2.58

Residual Moisture........ $0.86 \%$

As Received

Dry

Dry Ash-Free

PROXIMATE ANALYSIS D3172

Moisture............ 3.42

Ash................ 51.60

Volatile Matter........ 18.19

Fixed Carbon........... 26.79

-.....

ULTIMATE ANAIYSIS

100.00

Hydrogen.........D5373... 2.84

Carbon...........D5373 .. 34.86

Nitrogen.........D5373 .. 0.81

Sulfur..........D $4239 \ldots 1.79$

Oxygen..........D3176.. 8.10

$A \sin . . . \ldots \ldots . . . D 3174 \ldots 51.60$

1......

53.43

18.83

27.74

40.44

59.56

$1 . . .-1$

-......

100.00

100.00

2.55

5.47

36.09

0.84

1.86

5.23

53.43

100.00

-......

100.00

77.50

1. 80

3.99

11.24

......

100.00

Heating Value(BTU/Lb) D1989 6300

6523

14008

FORMS OF SULFUR D2492

Sulfate sulfur......... 0.01

Pyritic Sulfur.......... 1.20

Organic Sulfur........ 0.58

$\begin{array}{ll}0.01 & 0.02 \\ 1.24 & 2.66 \\ 0.61 & 1.31\end{array}$

Free Swelling Index $\$ 720$

1. 0

Equilibrium Moisture D1412-93

Hardgrove Grind. Index D409

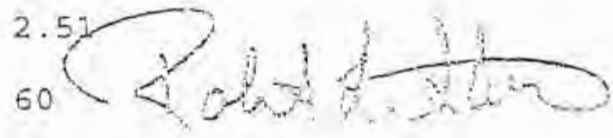

Robert I. Stuli

$M E M B E R$

药

Director of coal Services 


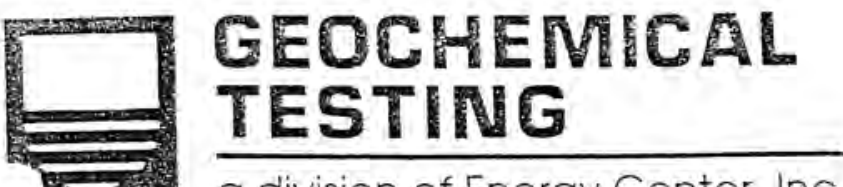

COAI ANALYSIS REPORT
2005 N Center Ave Somerset PA 15501

814/443-1671

$814 / 445-6666$

FAX: 814/445-6729

Client: US GEOLOGICAI SURVEY-CO (MCHG)

Sampled by: E.R. Landis

Sampling Date: 01/26/1999

Analyzed on: 02/09/1999

Description: Zobak Mine Z1

IAB NO. 99-013048

Ash Fusion (Reducing Atmosphere)

Temp of $\quad 2800+\frac{2800+}{}$

Ash Fusion (Oxidizing Atmosphere)

$\begin{array}{ccc} & \text { Initial D. } & \text { Softening } \\ \text { Temp o } & 2800+ & 2800+\end{array}$

T. Hemi T.

$2800+$

Fluid $T$.

$2800+2800+$

Apparent Specific Gravity .... 1.76

Page: 2

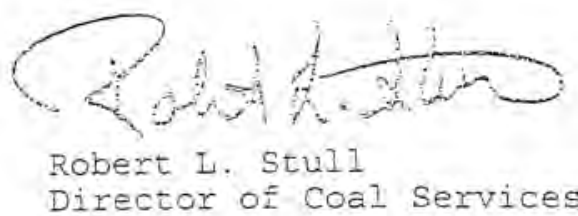




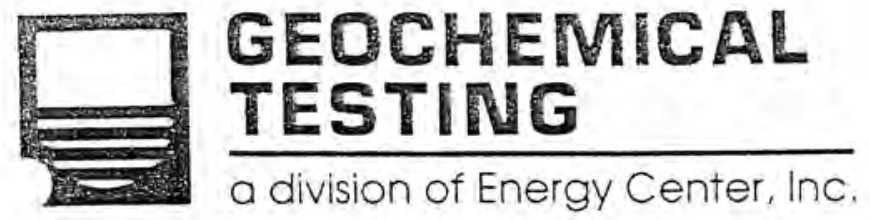

COAL ANALYSIS REPORT
2005 N Center Ave Somerset PA 15501

$814 / 443-1671$ $814 / 445-6666$ FAX: 814/445-6729

Client: US GEOLOGICAI SURVEY-CO (MCHG)

Sampled by: E.R. Landis

Sampling Date: 01/26/1999

Analyzed on: 02/09/1999

Description: Zobak Mine $\mathrm{Z} 2$

IAB NO. 99-013049

Air Dry Loss............. 2. 2.53\%

Residual Moisture........ 0.57 \%

As Received

Dry

Dry Ash-Free

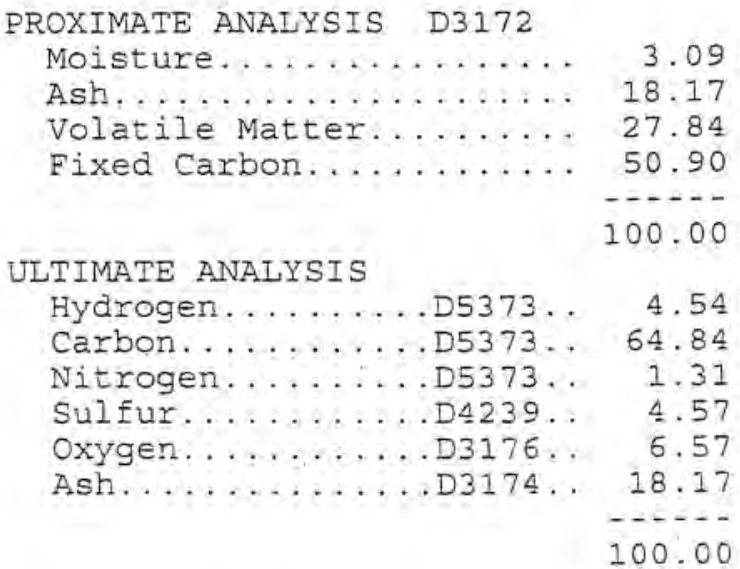

$$
18.75
$$

4. 72

3.94

18.75

.......

100.00

100.00

12257

15085

0.01

0.01

3. 31

4.07

1. 40

1.73

3.5

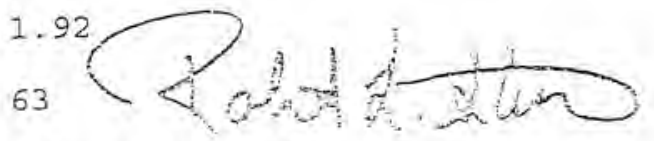

Robert I. Stull

Director of Coal Services 


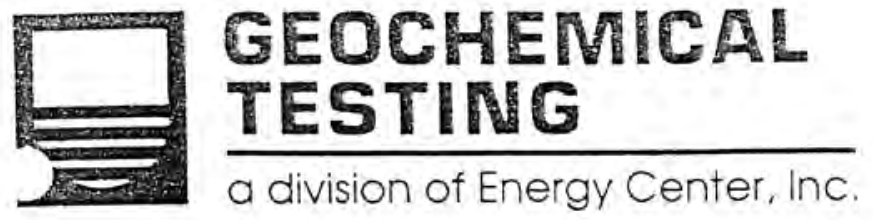

COAL ANALYSIS REPORT
$2005 \mathrm{~N}$ Center Ave Somerset PA 15501

$814 / 443-1671$

$814 / 445-6666$

FAX: 814/445-6729

Client: US GEOLOGICAL SURVEY-CO (MCHG)

Sampled by: E.R. Landis

Sampling Date: 01/26/1999

Analyzed on: 02/09/1999

Description: Zobak Mine $\quad$ Z2

LAB NO. 99-013049

Ash Fusion (Reducing Atmosphere)

Initial D. Softening $T$.

Temp OF $2170 \quad 2330 \quad 2390$

Ash Fusion (Oxidizing Atmosphere)

Initial D. Softening $T$. Hemi $T$. Fluid $I$.

$\begin{array}{lllll}\text { Temp o F } & 2560 & 2610 & 2630 & 2660\end{array}$

Apparent Specific Gravity .... 1.38

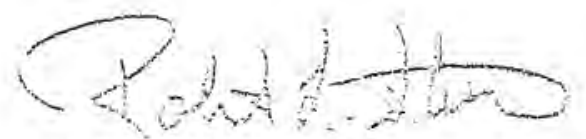

Robert L. Stull

Director of Coal Services 

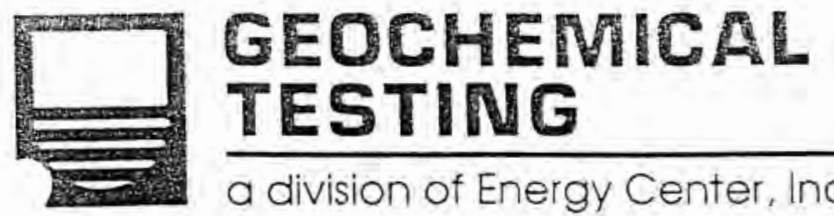

2005 N Center Ave Somerset PA 15501

a division of Energy Center, Inc.

$814 / 443-1671$

$814 / 445-6666$

FAX: 814/445-6729

COAL ANAIYSIS REPORT

Client: US GEOLOGICAI SURVEY-CO (MCHG)

Sampled by: E.R. Landis

Sampling Date: 01/26/1999

Analyzed on: 02/09/1999

Description: Zobak Mine Z3

LAB NO. 99-013050

Air Dry Loss.............. $2.36 \%$
Residual Moisture......... $1.12 \%$

As Received

Dry

Dry Ash-Free

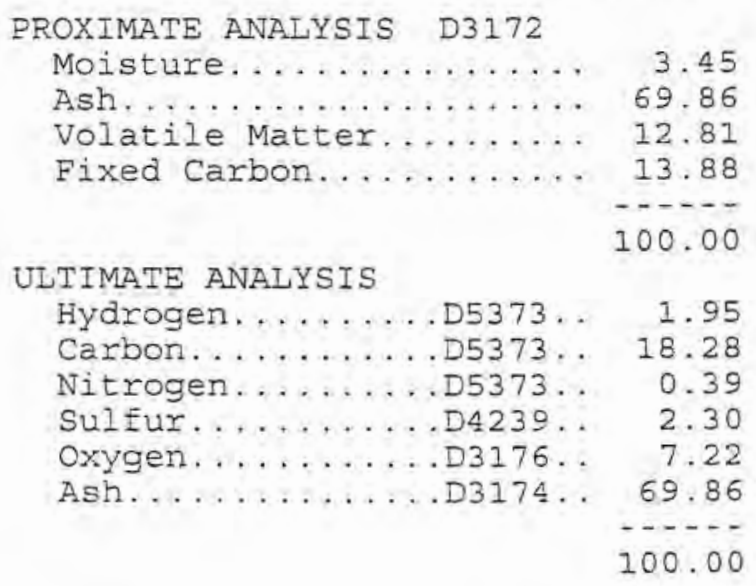

Heating Value(BTU/Lb) D1989 3145

72.36

13.27

14.37

48.01

......

51.99

100.00

100.00

I. 62

18.93

5.87

68.50

1. 46

0.40

2. 39

4.30

8.64

15.53

72.36

-.....

100.00

100.00

FORMS OF SULFUR
Sulfate Sulfur...........

3258

11786

Free Swelling Index D720

1.0

Equilibrium Moisture D1412-93

Hardgrove Grind. Index D409

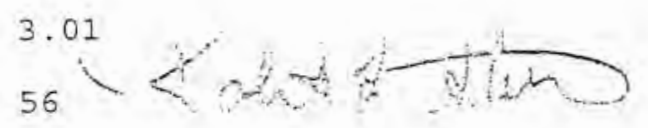

Robert I. Stull

Director of Coal Services 
2005 N Center Ave Somerset PA 15501

$814 / 443-1671$

$814 / 445-6666$

FAX: 814/445-6729

Client: US GEOLOGICAL SURVEY-CO (MCHG)

Sampled by: E.R. Landis

Sampling Date: 01/26/1999

Analyzed on: 02/09/1999

Description: Zobak Mine Z3

LAB NO. 99-013050

Ash Fusion (Reducing Atmosphere)

Initial D. Softening

Temp of $2800+2800+$

Ash Fusion (Oxidizing Atmosphere)

Initial D. Softening T. Hemi T. Fluid T.

Temp of $2800+2800+2800+2800+$

Apparent Specific Gravity ... 2. 2.08
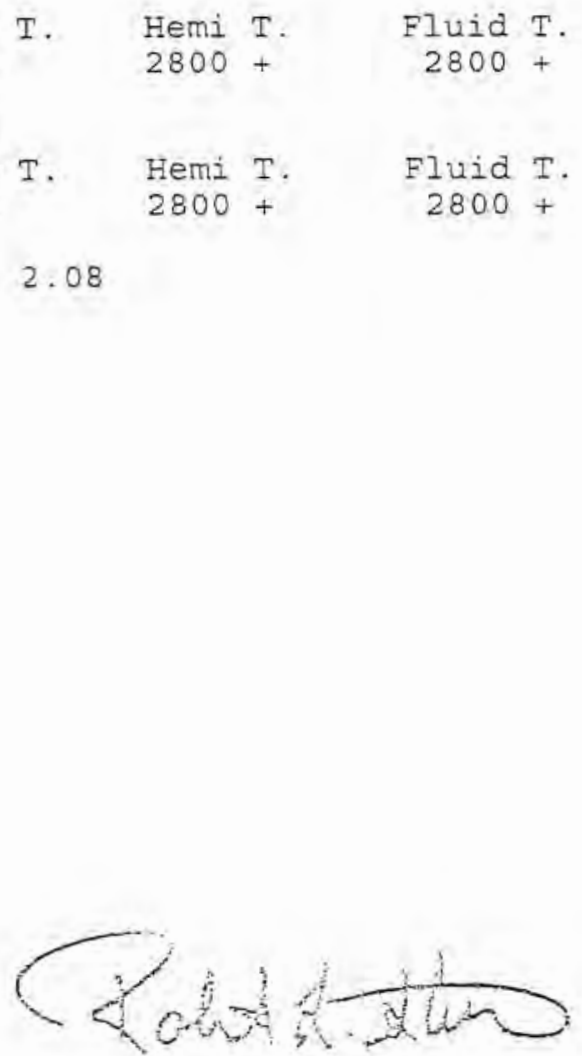

Robert I. Stull

Director of coal Services 

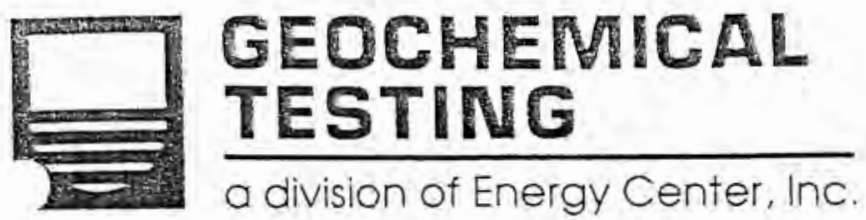

2005 N Center Ave Somerset PA 15501

814/443-1671

814/445-6666

FAX: $814 / 445-6729$

COAL ANALYSIS REPORT

Client: US GEOLOGICAI, SURVEY-CO (MCHG)

Sampled by: E.R. Landis

Sampling Date: 01/26/1999

Analyzed on: 02/09/1999

Description: Zobak Mine

LAB NO. 99-013051

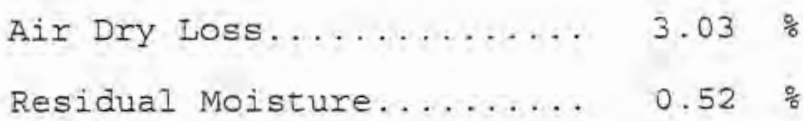

As Received

Dry

Dry Ash-Free

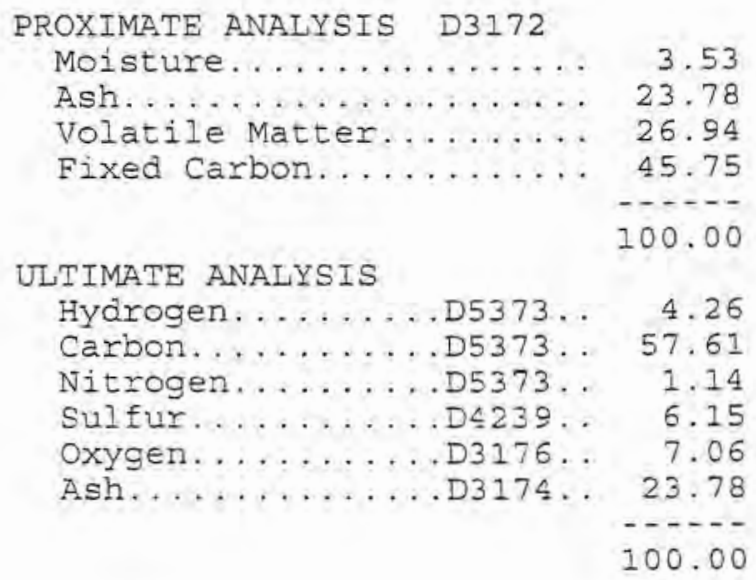

Heating Value(BTU/Lb) D1989 10684

24.65

27.93

47.42

-.....

100.00

4.00

59.72

24.65

…..

100.00

11075

FORMS OF SULFUR D2492

Sulfate sulfur......... 0.12

Pyritic Sulfur......... 5.17

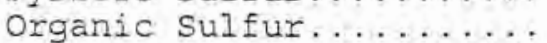

0.86
1. 19

6.37

4.07

14698

37.06

62.94

-.....

100.00

5.31

79.26

1. 57

8.46

5.40

- . . . .

100.00

0.12

5.36

0.89
0.16

7.11

1. 19
Free Swelling Index D720

Equilibrium Moisture D1412-93

Hardgrove Grind. Index DA09
3.0

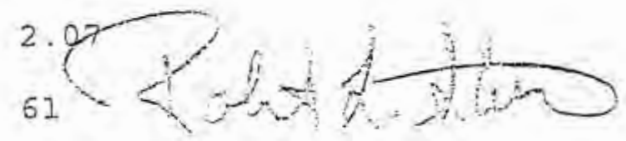

Robert I. Stull

Director of Coal Services 
2005 N Center Ave Somerset PA 15501

$814 / 443-1671$

814/445-6666

FAX: 814/445-6729

COAL ANALYSIS REPORT
Page: 2

Client: US GEOLOGICAL SURVEY-CO (MCHG)

Sampled by: E.R. Landis

Sampling Date: 01/26/1999

Analyzed on: 02/09/1999

Description: Zobak Mine $\mathrm{Z} 4$

LAB NO. 99-013051

Ash Fusion (Reducing Atmosphere)

Initial D. Softening $T$. Hemi $T$. Fluid $T$.

Ash Fusion (Oxidizing Atmosphere)

Initial D. Softening $T$. Hemi $T$. Fluid $T$.

$\begin{array}{lllll}\text { Temp } O F & 2580 & 2610 & 2630 & 2660\end{array}$

Apparent Specific Gravity ... $\quad 1.49$ 


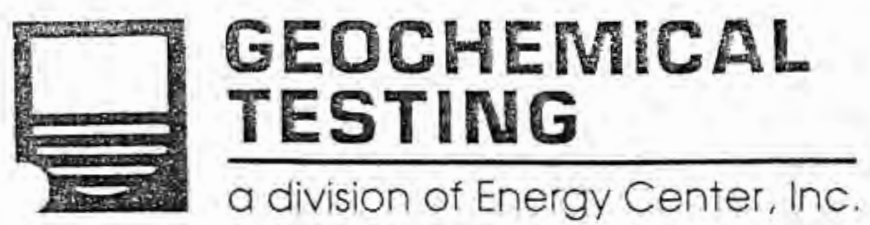

2005 N Center Ave Somerset PA 15501

$814 / 443-1671$

$814 / 445-6666$

FAX: 814/445-6729

COAL ANALYSIS REPORT

Client: US GEOLOGICAI SURVEY-CO (MCHG)

Sampled by: E.R. Landis

Sampling Date: 01/26/1999

Analyzed on: 02/09/1999

Description: Zobak Mine 25

LAB NO. 99-013052

Air Dry Loss............. 3. 3.69\%

Residual Moisture......... 1.31 \%

As Received

Dry

Dry Ash-Free

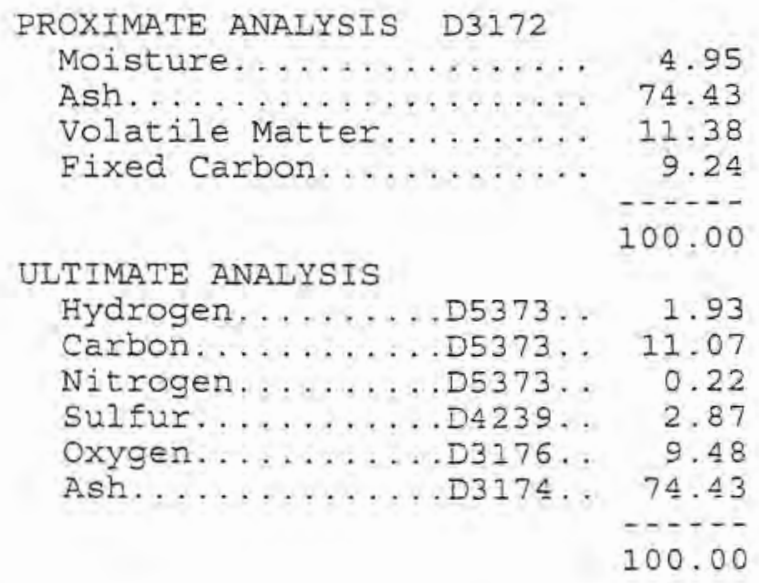

Heating Value(BTU/Lb) D1989 2003

FORMS OF SULFUR D2492

Sulfate Sulfur......... 0.04

Pyritic Sulfur......... 2.60

Organic Sulfur.......... 0.23
78.31

11.98

9.71

-.....

100.00

1.45

11.64

0.23

3.02

5.35

78.31

-.....

100.00

2107

0.04

2. 74

0.24
9712

55.21

44.79

100.00

6.70

53.67

1.07

13.92

24.64

- . . .

100.00

0.19

12.61

1.12

Free Swelling Index D720

0.5

Equilibrium Moisture D1412-93

Hardgrove Grind. Index D409

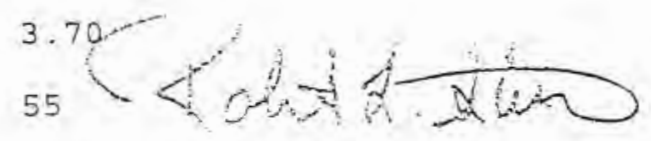

Robert I. Stull

Director of Coal Services 


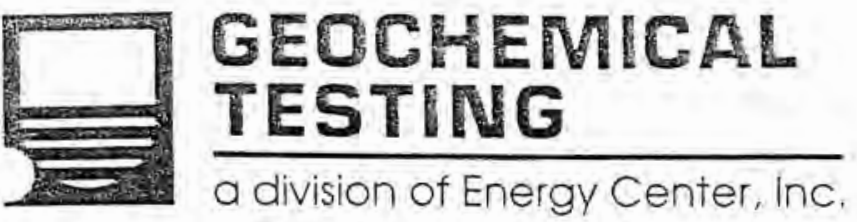

2005 N Center Ave Somerset PA 15501

$814 / 443-1671$

814/445-6666

FAX: 814/445-6729

Client: US GEOLOGICAL SURVEY-CO (MCHG)

Sampled by: E.R. Landis

Sampling Date: 01/26/1999

Analyzed on: 02/09/1999

Description: Zobak Mine Z5

ILAB NO. 99-013052

Ash Fusion (Reducing Atmosphere)

Initial D. Softening

Temp OF $2800+2800+$

Hemi T. FIuid $T$.

$2800+2800+$

Ash Fusion (Oxidizing Atmosphere)

Initial D. Softening $T$. Hemi $T$. Fluid $T$.

Temp OF $2800+2800+2800+2800+$

Apparent Specific Gravity ... $\quad 2.22$

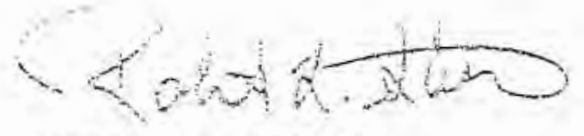

Robert I. Stull

Director of coal services 
Client: US GEOLOGICAL SURVEY-CO (MCHG)

Sampled by: E.R. Landis

Sampling Date: 01/26/1999

Analyzed on: 02/09/1999

Description: Zobak Mine Z6

LAB NO. 99-013053

Air Dry Loss............ $2.46 \%$
Residual Moisture........ $0.63 \%$

As Received

Dry

Dry Ash-Free

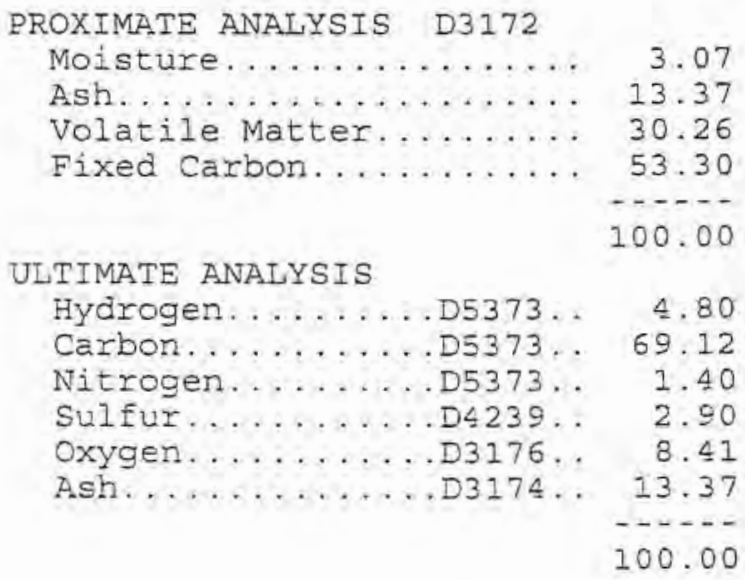

Heating Value(BTU/Lb) D1989 12564

EORMS OF SULFUR D2492

Sulfate Sulfur......... 0.01

Pyritic Sulfur.......... 1.70

Organic sulfur......... 1.19

Free Swelling Index D720

Equilibrium Moisture D1412-93

Hardgrove Grind Index D409

MEMBER

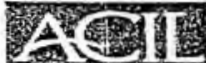

13.80

31.22

54.98

......

100.00

4.60

71.32

1.45

2.99

5.85

13.80

-.....

100.00

12962

15037

0.01
1.75
1.23

0.01

2.03

1. 43

36.21

63.79

100.00

5.33

82.72

1. 68

3.47

6.80

100.00
6. 0

2.10

70

Robert I. Stull

Director of Coal Services 


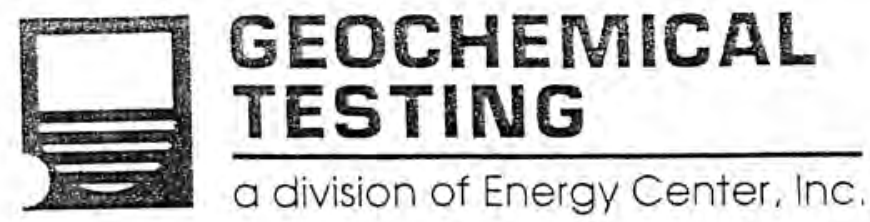

2005 N Center Ave Somerset PA 15501

$814 / 443-1671$

$814 / 445-6666$

FAX: $814 / 445-6729$

COAL ANALYSIS REPORT

Page:

2

Client: US GEOLOGICAI SURVEY-CO (MCHG)

Sampled by: E.R. Landis

Sampling Date: 01/26/1999

Analyzed on: 02/09/1999

Description: Zobak Mine Z6

LAB NO. 99-013053

Ash Fusion (Reducing Atmosphere)

Initial D. Softening $T$.

Ash Fusion (Oxidizing Atmosphere)

Initial D. Softening $T$. Hemi $T$. Fluid $T$.

Temp of $2700 \quad 2720$

Apparent Specific Gravity .... 1.28

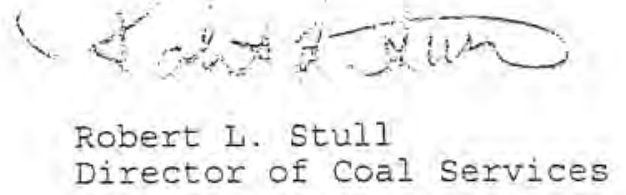




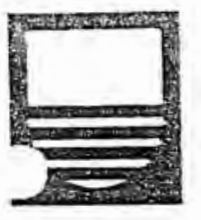

Client: US GEOLOGICAI SURVEY-CO (MCHG)

Sampled by: E.R. Landis

Sampling Date: 01/26/1999

Analyzed on: 02/04/1999

Description: Armin Mine AI

IAB NO. 99-012896

Air Dry Loss............ $21.61 \%$

Residual Moisture....... 5.05 \%

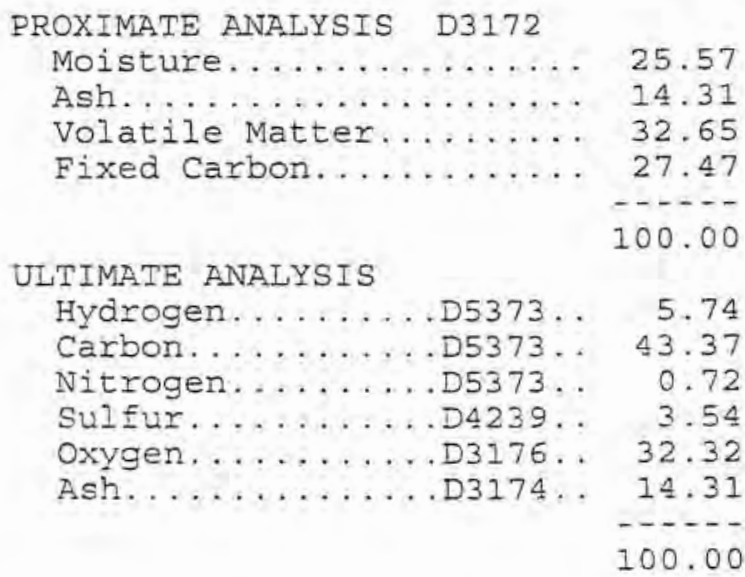




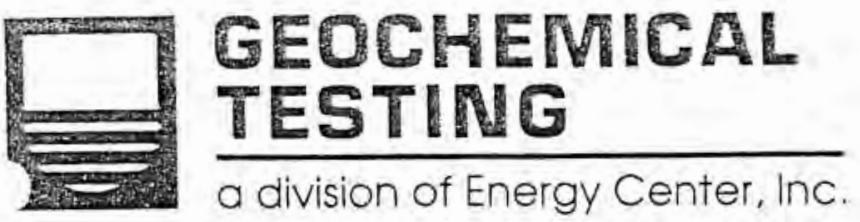

$2005 \mathrm{~N}$ Center Ave Somerset PA 15501

814/443-1671

$814 / 445-6666$

FAX: 814/445-6729

COAI ANAIYSIS REPORT

Page: 2

Client: US GEOLOGICAL SURVEY-CO (MCHG)

Sampled by: E.R. Landis

Sampling Date: 01/26/1999

Analyzed on: 02/04/1999

Description: Armin Mine A1

LAB NO. 99-012896

Ash Fusion (Reducing Atmosphere)

Initial D. Softening $T$. Hemi T. Fluid T.

Temp of $2720 \quad 2760$

$2770 \quad 2780$

Ash Fusion (Oxidizing Atmosphere)

Temp o F $2200 \quad 2210$

Hemi T. Fluid $T$.

2250

2380

Apparent Specific Gravity .... 1.49

NOTE: Insufficient material to run HGI determination.

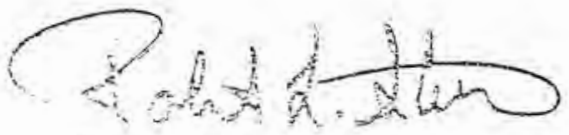

Robert I. StulI

Director of Coal Services 


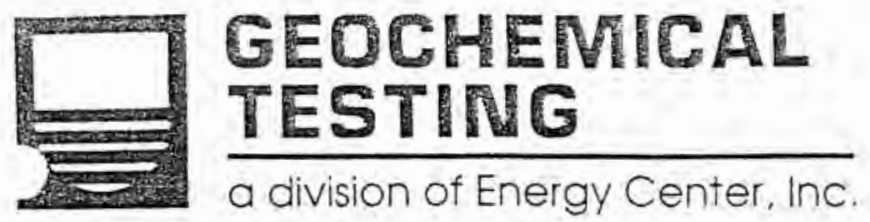

$2005 \mathrm{~N}$ Center Ave Somerset PA 15501

814/443-1671

$814 / 445-6666$

FAX: $814 / 445-6729$

COAL ANALYSIS REPORT

CIient: US GEOLOGICAI SURVEY-CO (MCHG)

Sampled by: E.R. Landis

Sampling Date; 01/26/1999

Analyzed on: 02/04/1999

Description: Armin Mire A2

IAB NO. 99-012895

Air Dry Loss............ 18.58 \%

Residual Moisture........ $0.75 \%$

As Received

Dry

Dry Ash-Eree

Total Moisture...D3302.... 19.19

Ash...........D3174... 43.36

SuIfur........... D4239... 0.01

BTU/LB...........D1989.... 707

Free Swelling Index D720

0.0

Lbs Sulfur/Milizon Btu

0.14

53.56

0.01

875

1889 


\section{This page left blank intentionally.}


Client: US GEOLOGICAL SURVEY-CO (MCHG)

Sampled by: E.R. Landis

Sampling Date: 01/26/1999

Analyzed on: 02/04/1999

Description: Armin Mine A3

LAB NO. 99-012897

Air Dry Loss............. $15.94 \%$
Residual Moisture........ $2.16 \%$

As Received

Dry

Dry Ash-Free

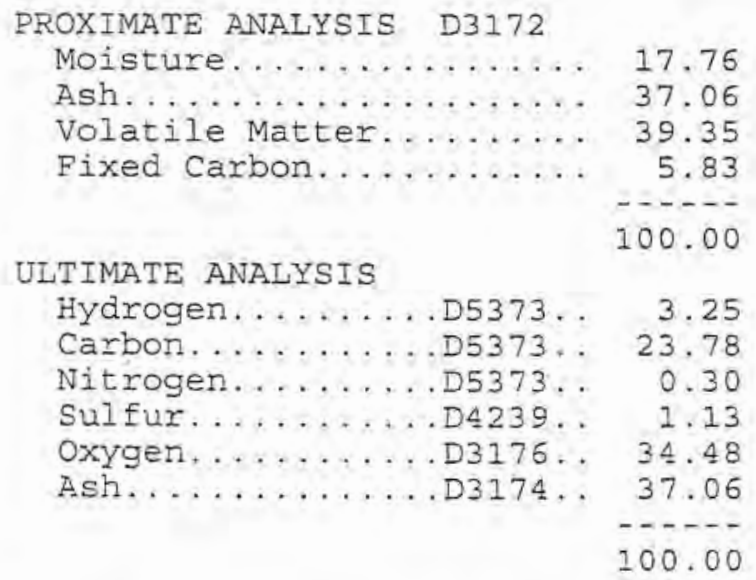

45.06

47.85

7.09

-.....

100.00

1.53

28.91

0.37

22.76

45.06

-.....

100,00

Heating Value(BTU/Lb) D1989 2798

FORMS OF SULFUR D2492

Sulfate sulfur................ 0.03

Pyritic sulfur.......... 0.16

organic sulfur........... 0.94

Free Swelling Index D720

Equilibrium Moisture D1412-93

$M E M B E R$

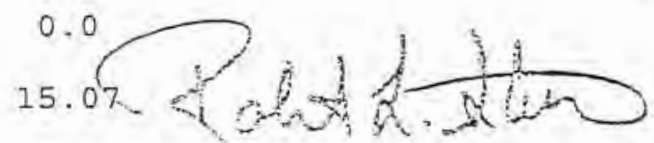

Robert I. Stull

Director of Coal Services
1. 37

3402

6192

87.11

12.89

100.00

2.79

52.63

0.67

2. 49

$\leq 1.42$

100.00

$0.03 \quad 0.06$

$0.19 \quad 0.35$ $\begin{array}{ll}1.15 & 2.08\end{array}$ 
2005 N Center Ave Somerset PA 15501

$814 / 443-1671$

$814 / 445-6666$

FAX: 814/445-6729

Client: US GEOLOGICAL SURVEY-CO (MCHG)

Sampled by: E.R. Landis

Sampling Date: 01/26/1999

Analyzed on: 02/04/1999

Description: Armin Mine A3

LAB NO. 99-012897

Ash Fusion (Reducing Atmosphere)

Temp of $\quad \begin{array}{cc}\text { Initial D. } & 2740\end{array}$

Hemi T. Fluid T.

Ash Fusion (Oxidizing Atmosphere)

Temp of $\quad \begin{array}{cc}\text { Initial D. } & \text { Softening } \\ 2690 & 2700\end{array}$

T. Hemí $T$, Fluid $T$.

Apparent Specific Gravity .... $\quad 1.75$

NOTE: Insufficient material to run HGI determination.

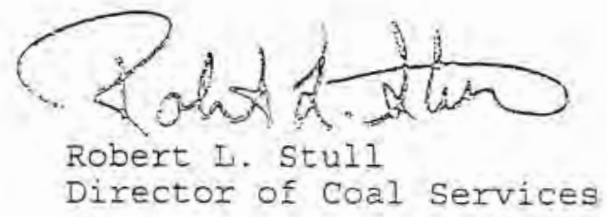


2005 N Center Ave Somerset PA 15501

814/443-1671

$814 / 445-6666$

FAX: 814/445-6729

COAI ANALYSIS REPORT

Client: US GEOLOGICAL SURVEY-CO (MCHG)

Sampled by: E.R. Landis

Sampling Date: 01/26/1999

Analyzed on: 02/04/1999

Description: Armin Mine A4

I.AB NO. 99-012898

Air Dry Loss............. 22.54 \%
Residual Moisture........ $5.49 \%$

As Received

Dry

Dry Ash-Free

PROXIMATE ANALYSIS D3172

Moisture.............. 26.79

Ash................ 12.80

Volatile Matter........ 32.35

Fixed Carbon.......... 28.06

-.....

ULTIMATE ANALYSIS

100.00

Hydrogen.........D5373 .. 5.98

Carbon..........D5373 . 43.70

Nitrogen.........D5373.. 0,88

Sulfur.........D4239.. 3.51

Oxygen..........D3176.. 33.13

Ash..........D3174.. 12.80

-.....

100.00

17.48

44.19

38.33

-.....

100.00

4.08

59.70

1. 20

4.79

12.75

17.48

-.....

100.00

0352

12545

Heating Value (BTU/Lb) D1989 7579

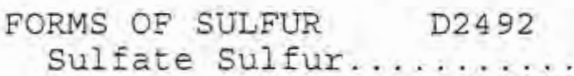

Sulfate Sulfur......... 0.07

Pyritic Sulfur.......... 0.24

Organic sulfur......... 3.20

Free Swelling Index D720

Equilibrium Moisture D1412-93

ME MBER

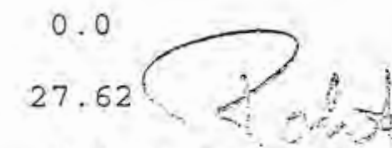

Robert I. StuIl
0.10
0.12
0.33
0.40
5.29

4.94

72.34

1. 45

5.81

15.46

100.00

100.00

Director of Coal Services 


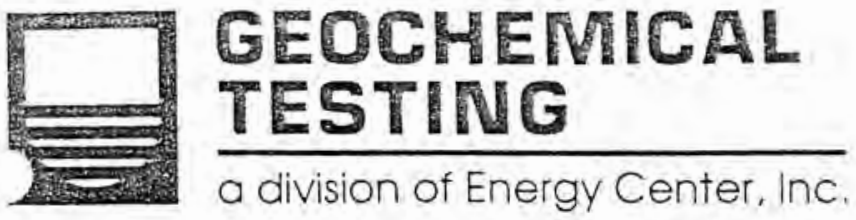

2005 N Center Ave Somerset PA 15501

814/443-1671

$814 / 445-6666$

FAX: 814/445-6729

Client: US GEOLOGICAL SURVEY-CO (MCHG)

Sampled by: E.R. Landis

Sampling Date: 01/26/1999

Analyzed on: 02/04/1999

Description: Armin Mine A4

LAB NO. 99-012898

Ash Fusion (Reducing Atmosphere)

Initial D. Softening $T$. Hemi $T$. Fluid $T$.

Ash Fusion (Oxidizing Atmosphere)

$\begin{array}{ccr} & \text { Initial D. } & \text { Softening } \\ \text { Temp o } F & 2490 & 2590\end{array}$

T. Hemi T. Fluid $T$.

Apparent Specific Gravity .... 1.31

NOTE: Insufficient material to run HGI determination.

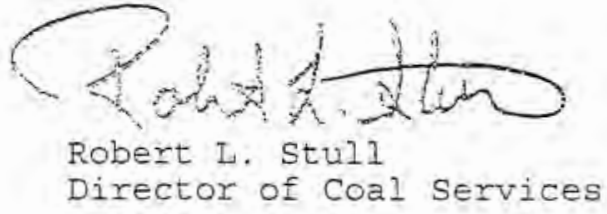


2005 N Center Ave Somerset PA 15501

814/443-1671

$814 / 445-6666$

FAX: 814/445-6729

COAL ANALYSIS REPORT

Client: US GEOLOGICAI SURVEY-CO (MCHG)

Sampled by: E.R. Landis

Sampling Date: 01/26/1999

Analyzed on: 02/04/1999

Description: Armin Mine A5

LAB NO. 99-012899

Air Dry Loss........... 16.86 \%

Residual Moisture........ 2.46 $\frac{0}{6}$

As Received

Dry

Dry Ash-Free

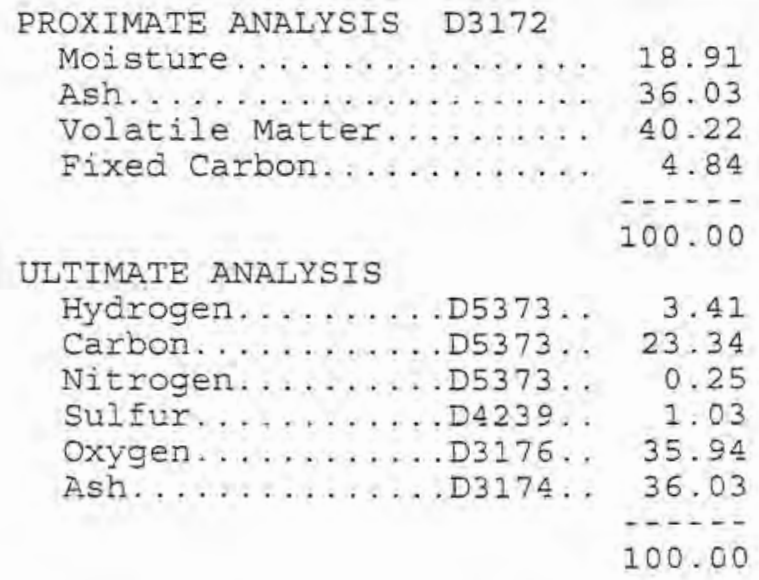

Heating Value(BTU/Lb) D1989 2746

FORMS OF SULFUR D2492

Sulfate Sulfur........ 0.04

pyritic sulfur.......... 0.06

Organic sulfur......... 0.93
44.43

49.60

5.97

…...

100.00

1. 59

28.78

0.31

1. 27

23.62

44.43

-......

100.00

3386

6093

Free Swelling Index D720

Equilibrium Moisture D1412-93
$0.05 \quad 0.09$

$0.07 \quad 0.13$

$\begin{array}{ll}1.15 & 2.07\end{array}$

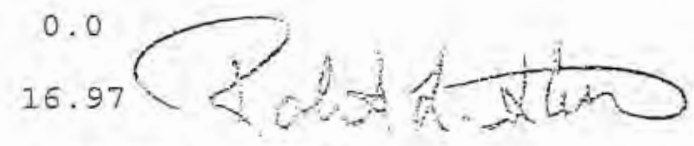

Robert I. Stull

Director of Coal Services 


\section{GEOCHEMICAL \\ TESTING}

2005 N Center Ave

Somerset PA 15501

$814 / 443-1671$

814/445-6666

FAX: 814/445-6729

COAI ANALYSIS REPORT

Page:

2

Client: US GEOLOGICAL SURVEY-CO (MCHG)

Sampled by: E.R. Landis

Sampling Date: 01/26/1999

Analyzed on: 02/04/1999

Description: Armin Mine A5

LAB NO. 99-012899

Ash Fusion (Reducing Atmosphere)

Temp o F $\quad \begin{array}{ccc}\text { Initial D. } & \text { Softening } \\ 2680 & 2700\end{array}$

Hemi T. Fluid T.

Ash Fusion (Oxidizing Atmosphere)

Temp of $2800+2800+$

T. Hemi T. Fluid T.

$2800+2800+$

Apparent Specific Gravity .... 1.93

NOTE: Insufficient material to run HGI determination.

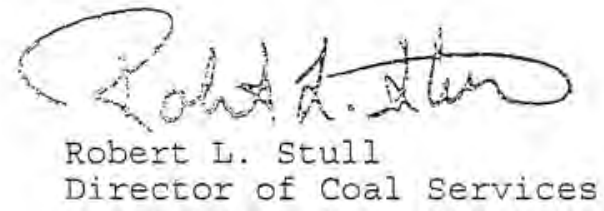



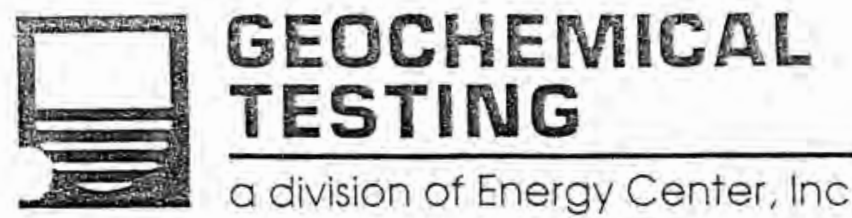

2005 N Center Ave Somerset PA 15501

814/443-1671

$814 / 445-6666$

a division of Energy Center, Inc.

FAX: 814/445-6729

COAL ANALYSIS REPORT

Client: US GEOLOGICAI SURVEY-CO (MCHG)

Sampled by: E.R. Landis

Sampling Date: 01/26/1999

Analyzed on: $02 / 04 / 1999$

Description: Armin Mine A6

LAB NO. 99-012900

Air Dry Loss............ $21.98 \%$
Residual Moisture........ $5.33 \%$

As Received

Dry

Dry Ash-Free
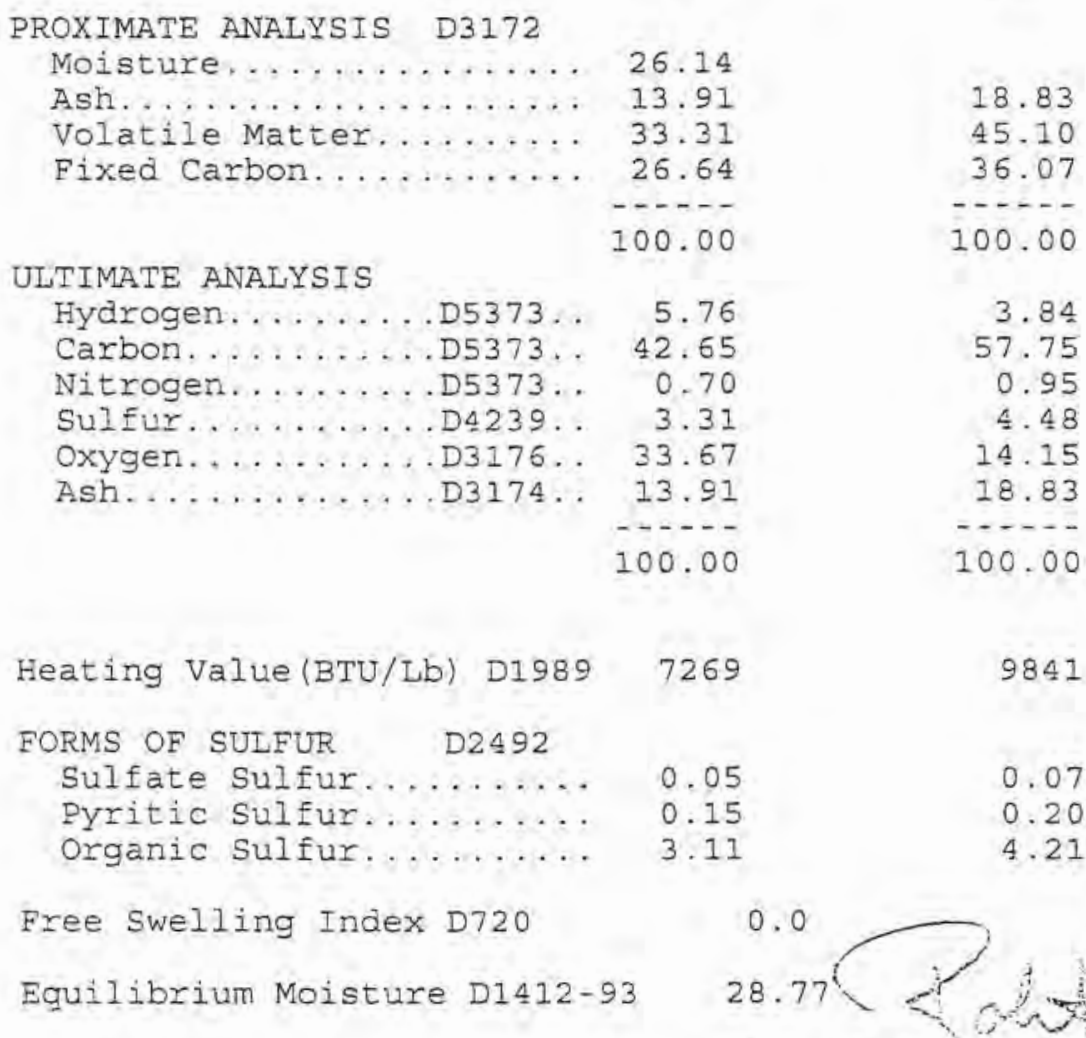

Robert L, Stull Director of Coal Services
18.83

45.10

36.07

100.00

3.84

57.75

0.95

4.48

14.15

18.83

100.00

9841

12125

0.07

0.09

0.25

5.18 
2005 N Center Ave Somerset PA 15501

814/443-1671

$814 / 445-6666$

FAX: 814/445-6729

Client: US GEOLOGICAL SURVEY-CO (MCHG)

Sampled by: E, R. Landis

Sampling Date: 01/26/1999

Analyzed on: 02/04/1999

Description: Armin Mine A6

LAB NO. 99-012900

Ash Fusion (Reducing Atmosphere)

$\begin{array}{ccc} & \text { Initial D. } & \text { Softening } \\ 2770 & 2780\end{array}$

Hemi I. Fluid T.

Ash Fusion (Oxidizing Atmosphere)

Initial D. Softening $T$. Hemi $T$. Fluid $T$.

Temp OF $2460 \quad 2640$

2720

2740

Apparent Specific Gravity .... 1.28

NOTE: Insufficient material to run HGI determination.

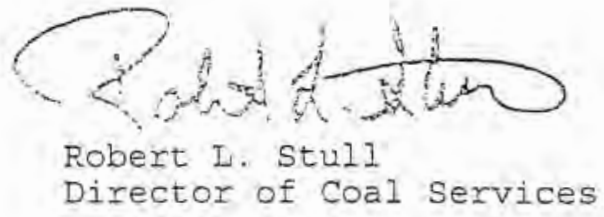


2005 N Center Ave Somerset PA 15501

$814 / 443-1671$

$814 / 445-6666$

FAX: $814 / 445-6729$

COAL ANALYSIS REPORT

Client: US GEOLOGICAI SURVEY-CO (MCHG)

Sampled by: E.R, Landis

Sampling Date: 01/26/1999

Analyzed on: 02/04/1999

Description: Armin Mine A7

IAB NO. 99-012901

Air Dry Loss............. $22.42 \%$

Residual Moisture........ $7.48 \%$

As Received

Dry

Dry Ash-Free

PROXIMATE ANALYSIS D3172

Moisture.............. 28.22

Ash................. 8.61

Volatile Matter........... 32.86

Fixed Carbon............ 30.31

-....

ULTIMATE ANALYSIS

100.00

Hydrogen........D5373..6.6.37

Carbon..........D5373 . 46.26

Nitrogen..........D5373 . . 0.99

Sulfur........... D4239.. 3.51

Oxygen.......... D3176 . 34.26

Ash...........D3174,.

-.....

100.00

12.00

45.77

42.23

-.....

100.00

4. 48

64.44

1.37

4.90

12.81

12.00

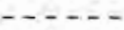

100.00

11352

12899

Heating Value(BTU/Lb) D1989 8148

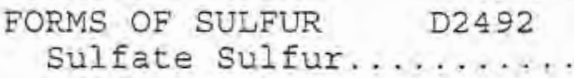

Pyritic sulfur...........

0.02

0.20

Organic sulfur...........

3. 29
0.02
0.28
4.50

0.02

0.32

5. 22

Free Swelling Index D720

0,0

Equilibrium Moisture D1412-93

Hardgrove Grind. Index D 409

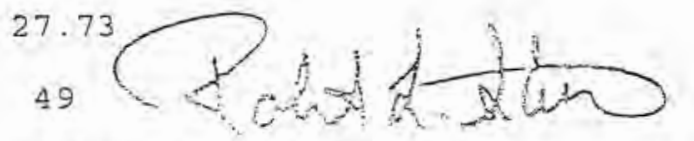

MEMBER

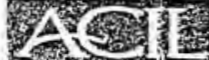

Robert I. Stull

Director of Coal Services 


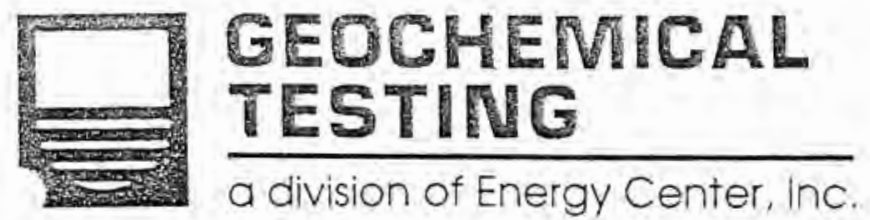

COAI ANALYSIS REPORT
2005 N Center Ave Somerset PA 15501

814/443-1671

814/445-6666

FAX: 814/445-6729

Client: US GEOLOGICAL SURVEY-CO (MCHG)

Sampled by: E.R. Landis

Sampling Date: 01/26/1999

Analyzed on: 02/04/1999

Description: Armin Mine A7

LAB NO. 99-012901

Ash Fusion (Reducing Atmosphere)

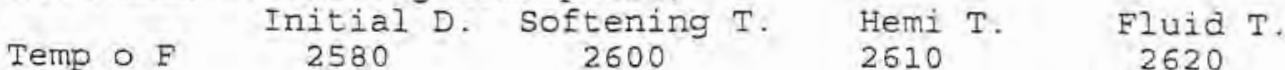

Ash Fusion (Oxidizing Atmosphere)

Initial D. Softening

Apparent Specific Gravity ... 1.31

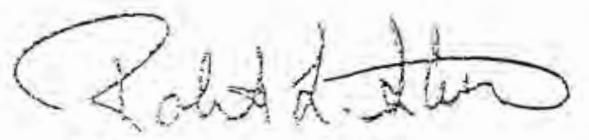

Robert I. Stull

Director of coal Services 
2005 N Center Ave Somerset PA 15501

814/443-1671

$814 / 445-6666$

FAX: $814 / 445-6729$

COAI ANAIYSIS REPORT

Client: US GEOLOGICAI SURVEY-CO (MCHG)

Sampled by: E.R. Landis

Sampling Date: $12 / 17 / 98$ TO $12 / 17 / 98$

Analyzed on: $01 / 02 / 99$

Description: Armin Mine A8

IAB NO. 99-012111

Air Dry Loss........... 20,64 \%

Residual Moisture........ 3.65

As Received

Dry

Dry Ash-Free

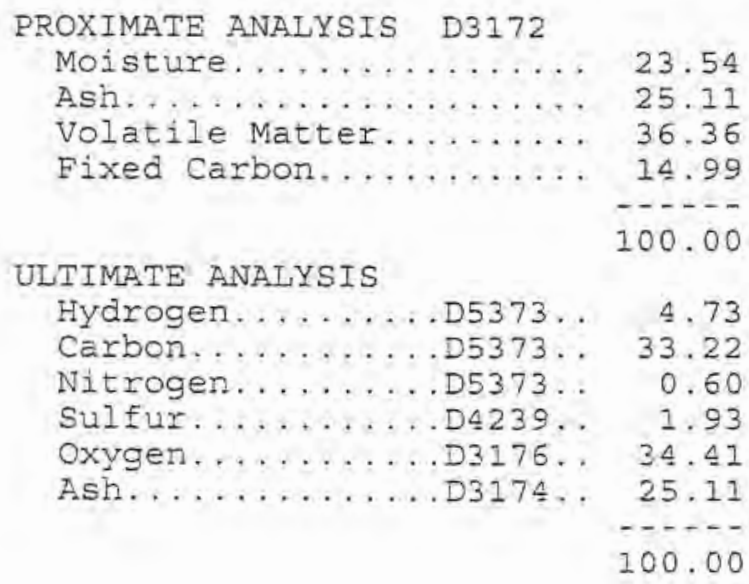

32.84

47.56

19.60

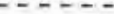

100.00

2.74

43.45

0.79

2.52

17.66

32.84

-.....

100.00

70.81

29.19

.......

100.00

4.08

64.69

1. 17

3.76

25.30

100.00

9960

0.04

0.06

0.14

2.39

3.56
0.0

23,20

Robert I. Stull

Director of Coal Services 


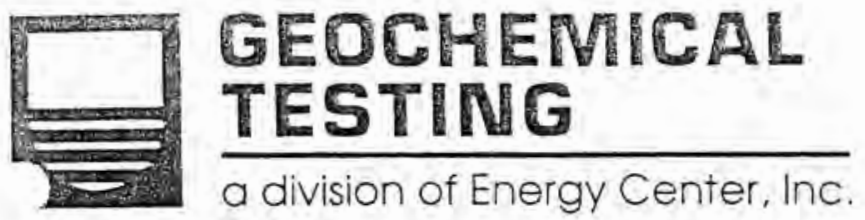

\author{
2005 N Center Ave \\ Somerset PA 15501 \\ $814 / 443-1671$ \\ $814 / 445-6666$ \\ FAX: $814 / 445-6729$
}

COAI ANALYSIS REPORT

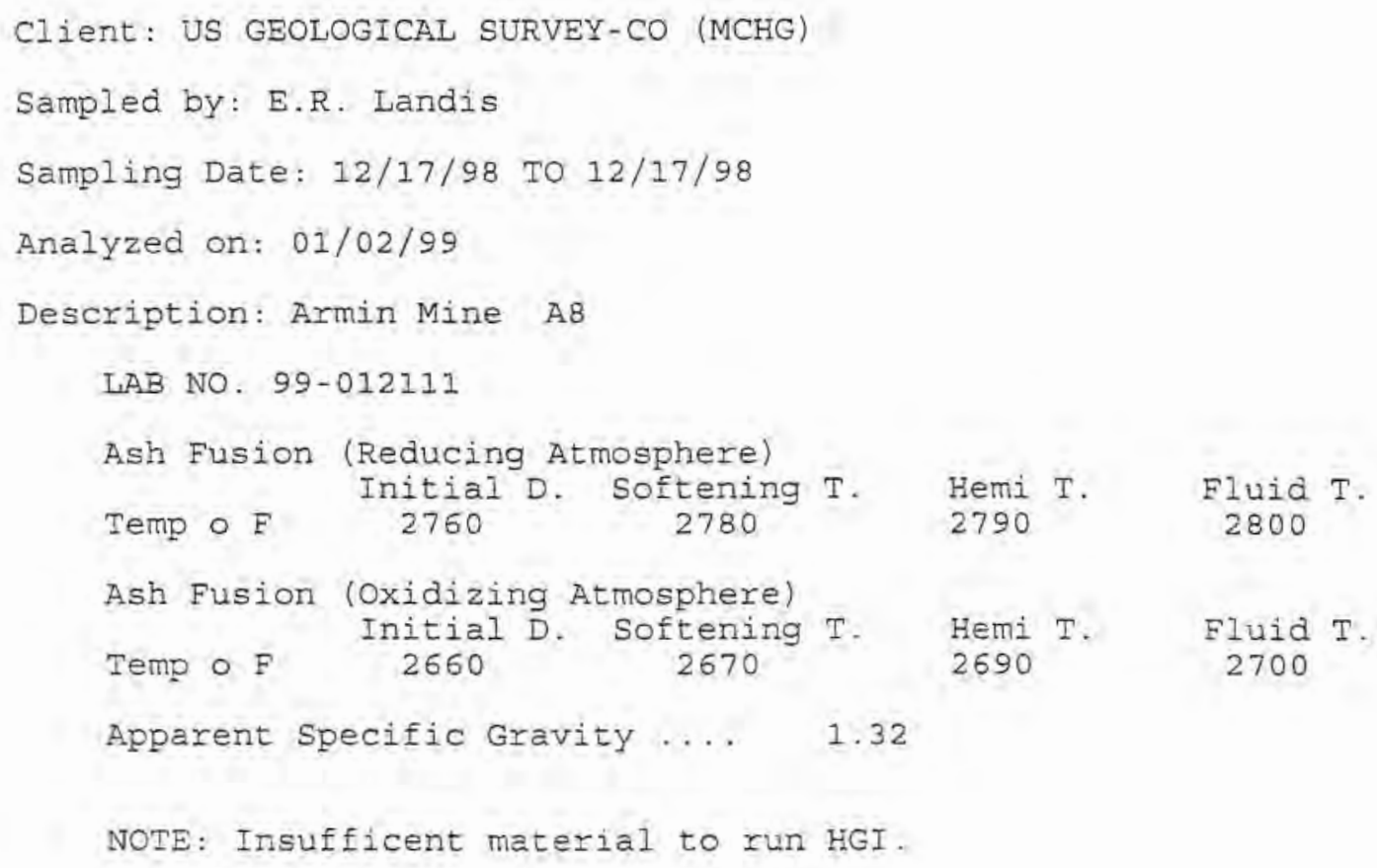


2005 N Center Ave Somerset PA 15501

814/443-1671

$814 / 445-6666$

FAX: 814/445-6729

COAL ANALYSIS REPORT

Client: US GEOLOGICAI SURVEY-CO (MCHG)

Sampled by: E.R. Landis

Sampling Date: 12/17/98 TO 12/17/98

Analyzed on: $01 / 02 / 99$

Description: Armin Mine A9

LAB NO. 99-012112

Air Dry Loss............. $17.54 \%$
Residual Moisture........ $3.61 \%$

As Received

Dry

Dry Ash-Free

PROXIMATE ANALYSIS D3172

Moisture............. 20.52

Ash................ 32.54

Volatile Matter........ 34.92

Fixed Carbon........... 12.02

100 .

ULTIMATE ANAIYSIS

100.00

Hydrogen........D5373.. 4.24

Carbon..........D5373 . 30.83

Nitrogen.........D5373.. 0.55

Sulzur..........D4239.. 2.79

Oxygen.........D3175 .. 29.05

Ash...........D3174.. 32.54

100.00

40.94

$\begin{array}{ll}43.94 & 74.39\end{array}$

$15.12 \quad 25.61$

-....

$100.00 \quad 100.00$

\begin{tabular}{rr}
2.44 & 4.14 \\
38.79 & 65.68 \\
0.70 & 1.18 \\
3.51 & 5.94 \\
13.62 & 23.06 \\
40.94 & \\
\hdashline. .0 & \\
100.00 & 100.00
\end{tabular}

Heating Value (BTU/Lb) D1989 4786

6021

10195

FORMS OF SULFUR D2492

Sulfate Sulfur......... 0.19

Pyritic sulfur.......... 0.98

Organic sulfur.......... 1.62

0.24

0.40

I. 23

2. 09

2. 04

3. 45

Eree Swelling Index D720

Equilibrium Moisture D1412-9.3

0.0

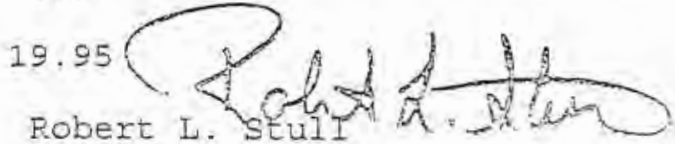

Director of coal Services 
2005 N Center Ave Somerset PA 15501

814/443-1671

$814 / 445-6666$

FAX: 814/445-6729

Client: US GEOLOGICAI SURVEY-CO (MCHG)

Sampled by: E.R. Landis

Sampling Date: 12/17/98 TO 12/17/98

Analyzed on: 01/02/99

Description: Armin Mine A9

LAB NO. 99-012112

Ash Fusion (Reducing Atmosphere)

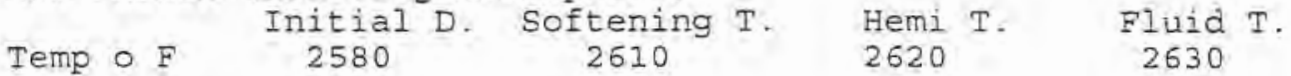

Ash Fusion (Oxidizing Atmosphere)

Initial D. Softening $T$. Hemi $T$. Fluid $T$.

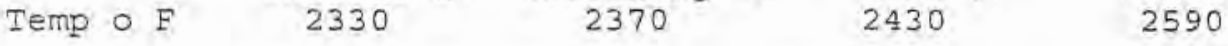

Apparent Specific Gravity ... $\quad 1.60$

NOTE: Insufficent material to run HGI.

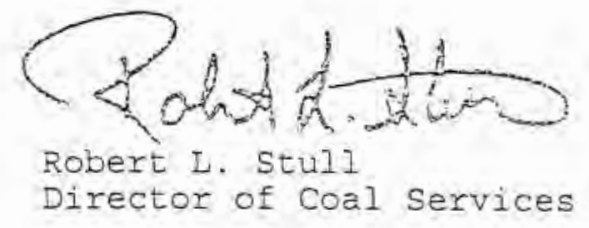


2005 N Center Ave Somerset PA 15501

$814 / 443-1671$

$814 / 445-6666$

FAX: 814/445-6729

COAL ANALYSIS REPORT

Client: US GEOLOGICAI SURVEY-CO (MCHG)

Sampled by: E.R. Landis

Sampling Date: 12/17/98 TO 12/17/98

Analyzed on: 01/02/99

Description: Armin Mine A10

IAB NO. 99-012113

Air Dry Loss............ $21.35 \%$
Residual Moisture........ $4.50 \%$

As Received

Dry

Dry Ash-Eree

PROXIMATE ANALYSIS D3172

Moisture............... 24.89

Ash................. 16.95

Volatile Matter........ 32.41

Fixed Carbon.......... 25.75

-......

ULTIMATE ANALYSIS

100.00

Hydrogen.........D5373, 5.72

Carbon......... D5373.. 42.68

Nitroger.........D5373.. 0.87

Sulfur...........D4239... 3.79

Oxygen..........D3176.. 29.99

Ash...........D3174.. 16.95

.......

100.00

22.57

43.15

34.28

55.73

.......

44.27

100.00

100.00

3.90

5.04

56.83

1.16

5.05

10.49

22.57

......

100.00

73.39

1. 50

6.52

13.55

-......

100.00

Heating Value(BTU/Lb) D1989 7440

9906

12792

FORMS OF SULFUR D2492

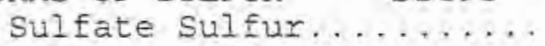

0.07

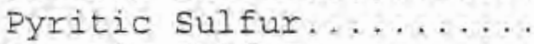

0.42

0.09

0.55

0.12

Organic sulfur..........

3.30

4,41

0.72

5.68

Free Swelling Index D720

0.0

Equilibrium Moisture D1412-93

24.75

Robert I.
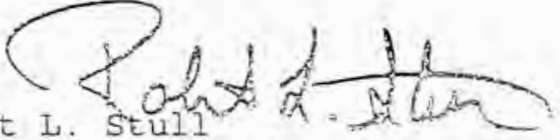

Director of Coal Services 


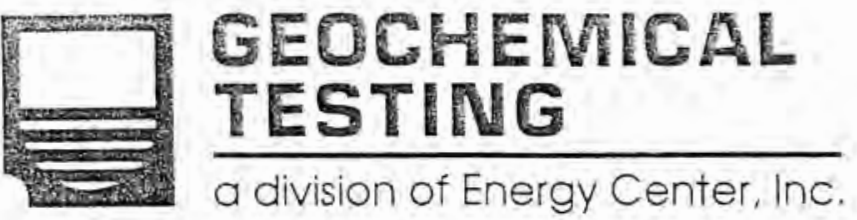

2005 N Center Ave Somerset PA 15501

814/443-1671

$814 / 445-6666$

FAX: 814/445-6729

Client: US GEOLOGICAI SURVEY-CO (MCHG)

Sampled by: E.R. Landis

Sampling Date: 12/17/98 To $12 / 17 / 98$

Analyzed on: 01/02/99

Description: Armin Mine AlO

LAB NO. 99-012113

Ash Fusion (Reducing Atmosphere)

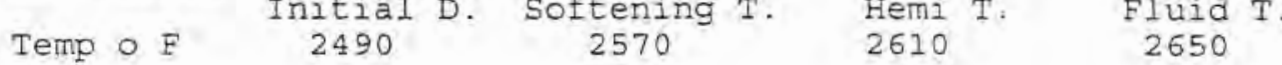

Ash Fusion (Oxidizing Atmosphere)

Initial D. Softening

Apparent Specific Gravity .... 1.26

NOTE: Insufficent material to run HGI. 
2005 N Center Ave Somerset PA 15501

814/443-1671

$814 / 445-6666$

FAX: $814 / 445-6729$

COAL ANAIYSIS REPORT

Client: US GEOLOGICAL SURVEY-CO (MCHG)

Sampled by: E.R. Landis

Sampling Date: 12/17/98 To $12 / 17 / 98$

Analyzed on: 01/02/99

Description: Armin Mine A11

IAB NO. 99-012114

Air Dry Loss.............. $19.21 \%$

Residual Moisture....... 3. 3.56 \%

As Received

Dry

Dry Ash-Free
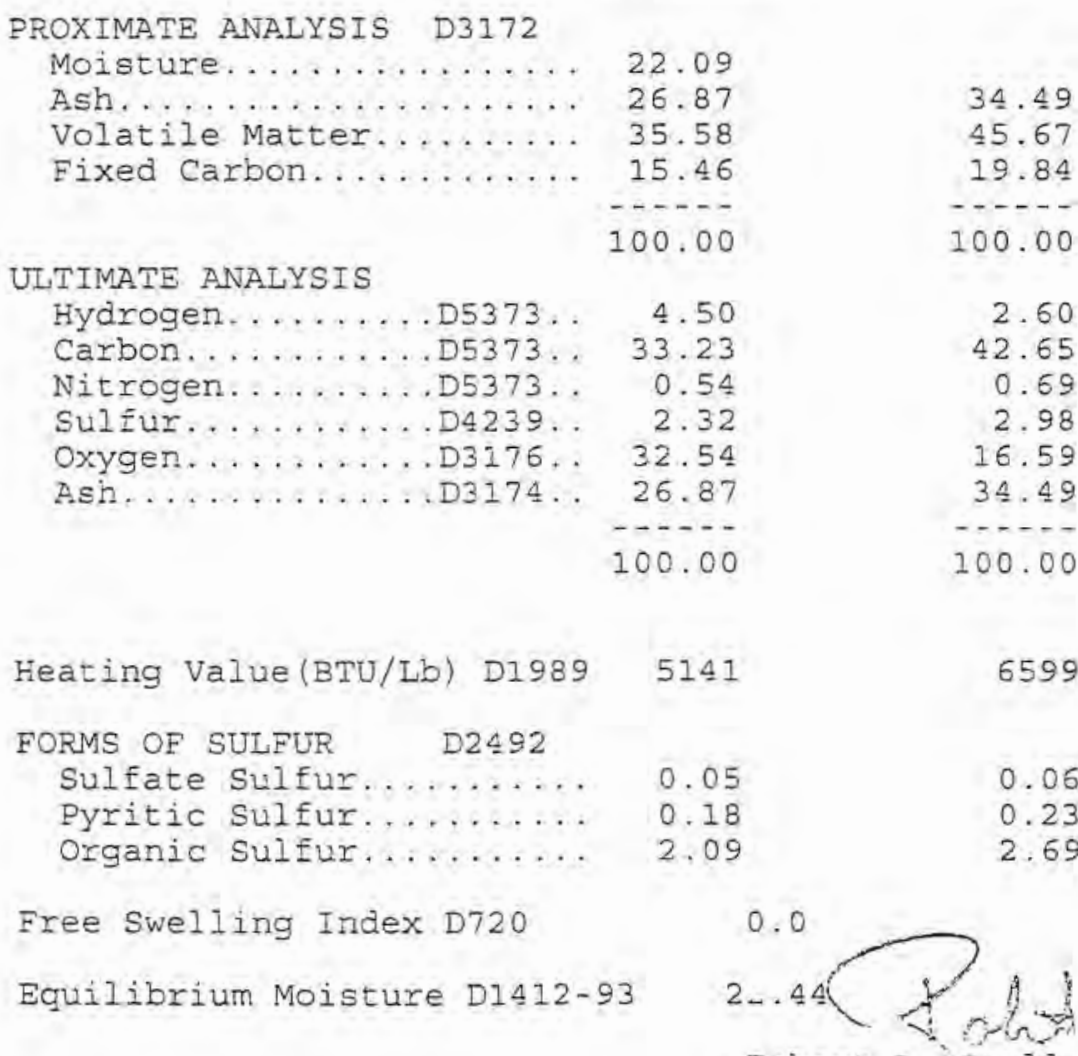

Robert I. Stul1 34.49 45.67 19.84 100.00

2. 60

42.65

0.69

2.98

16.59

34.49

100.00

6599

Director of Coal

$\begin{array}{ll}0.06 & 0.09 \\ 0.23 & 0.35 \\ 2.69 & 4.10\end{array}$

4. 10
10073

69.71

30.29

100.00

3.98

65,10

1.06

4.54

25.32

100.00

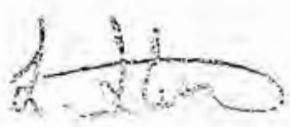

Services 
2005 N Center Ave Somerset PA 15501

814/443-1671

814/445-6666

FAX: $814 / 445-6729$

COAL ANALYSIS REPORT

Client: US GEOLOGICAI SURVEY-CO (MCHG)

Sampled by: E.R. Landis

Sampling Date: 12/17/98 TO 12/17/98

Analyzed on: 01/02/99

Description: Armin Mine A11

LAB NO. 99-012114

Ash Fusion (Reducing Atmosphere)

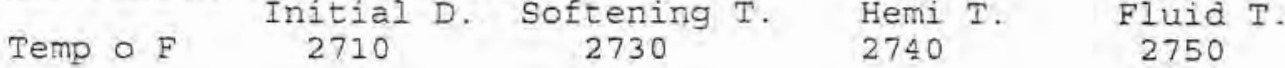

Ash Fusion (Oxidizing Atmosphere)

$\begin{array}{ccccc} & \text { Initial D. Softening T. } & \text { Hemi T. } & \text { Fluid T. } \\ \text { Temp O F } & 2720 & 2730 & 2740 & 2770\end{array}$

Apparent Specific Gravity ... 1.58

NOTE: Insufficent material to run HGI. 
2005 N Center Ave Somerset PA 15501

$814 / 443-1671$

814/445-6666

FAX: 814/445-6729

COAL ANALYSIS REPORT

Client: US GEOLOGICAI SURVEY-CO (MCHG)

Sampled by: E.R. Landis

Sampling Date: $12 / 17 / 98$ TO $12 / 17 / 98$

Analyzed on: $01 / 02 / 99$

Description: Armin Mine Al2

LAB NO. 99-012115

Air Dry Loss.............. $18.95 \%$

Residual Moisture........ 3.37 \%

As Received

Dry

Dry Ash-Eree

PROXIMATE ANALYSIS D3172

Moisture............. 21.68

Ash................ 26.73

Volatile Matter................... 35.83

Fixed Carbon........... 15.76

-.....

ULTIMATE ANAIYSIS

100.00

Hydrogen.........D5373..4 4.60

Carbon.........D5373.. 34.21

Nitrogen.........D5373,. 0.62

Sulfur..........D4239.. 2.28

Cxygen........D3176.. 31.56

Ash...........D3174.. 26.73

-.......

100.00

34.13

45.75

20.12

-......

100.00

69.46

30.54

100.00

2.78

4. 22

43.68

66.32

I. 21

2.81

15.70

4.41

23.84

34.13

-......

- ......

100.00

100.00

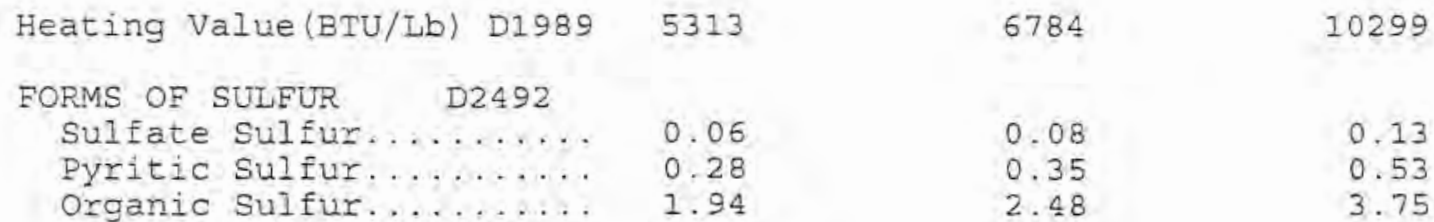

Free Swelling Index D720

0.0

Equilibrium Moisture D1412-93

20.86

Robert I. Stull

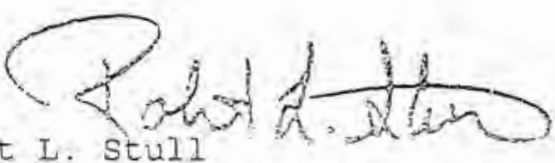

Director of Coal Services 
2005 N Center Ave Somerset PA 15501

$814 / 443-1671$

$814 / 445-6666$

FAX: 814/445-6729

Client: US GEOLOGICAI SURVEY-CO (MCHG)

Sampled by: E.R. Landis

Sampling Date: $12 / 17 / 98$ TO $12 / 17 / 98$

Analyzed on: $01 / 02 / 99$

Description: Armin Mine A.12

LAB NO. 99-012115

Ash Fusion (Reducing Atmosphere)

Temp o F $\begin{array}{ccccc}\text { Initial D. } & \text { Softening T. } & \text { Hemi } & \\ & 2610 & 2650 & 2660 & 2670\end{array}$

Ash Fusion (Oxidizing Atmosphere)

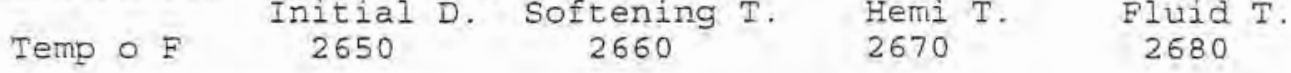

Ppparent Specific Gravity .... 1.54

NOTE: Insufficent material to run HGI. 
2005 N Center Ave Somerset PA 15501

814/443-1671

814/445-6666

FAX: 814/445-6729

COAL ANALYSIS REPORT

Client: US GEOLOGICAI SURVEY-CO (MCHG)

Sampled by: E.R. Landis

Sampling Date: 01/26/1999

Analyzed on: 02/04/1999

Description: Balinka Mine BI

LAB NO. 99-012902

Air Dry Loss.............. $9.39 \%$
Residual Moisture......... 1.08

As Received

Dry

Dry Ash-Free

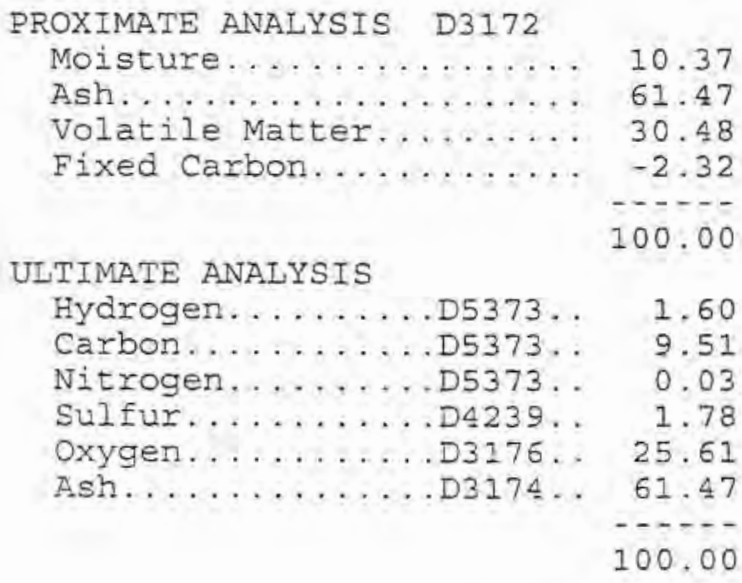

Heating Value(BTU/Lb) D1989 293

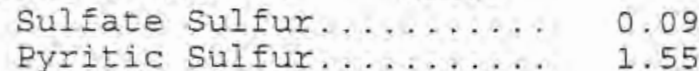

organic sulfur........... 0.14

68.58

34.01

$-2.59$

......

100.00

0.49

10.61

0.03

1. 99

18.30

68.58

…...

100.00
108.24

$-8.24$

.......

100.00

1.57

33.78

0.10

6.34

58.21

-.....

100.00

1040

Free Swelling Index D720

Equilibrium Moisture D1412-93

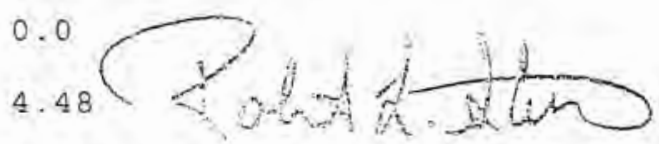

Robert I. Stull

Director of Coal Services 


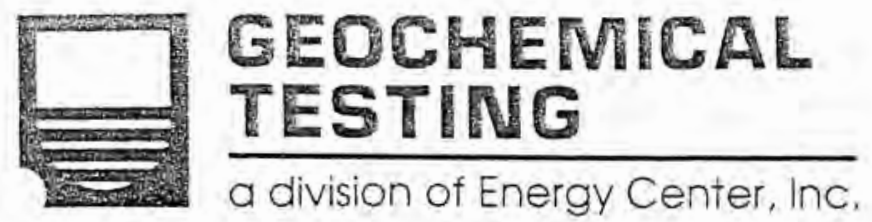

$2005 \mathrm{~N}$ Center Ave Somerset PA 15501

814/443-1671

$814 / 445-6666$

FAX: 814/445-6729

Client: US GEOLOGICAL SURVEY-CO (MCHG)

Sampled by: E.R. Landis

Sampling Date: 01/26/1999

Analyzed on: 02/04/1999

Description: Balinka Mine B1

IAB NO. 99-012902

Ash Fusion (Reducing Atmosphere)

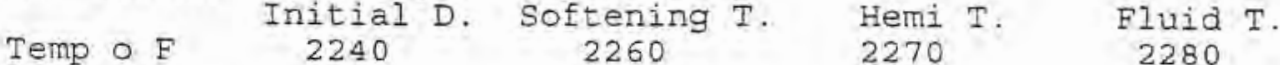

Ash Fusion (Oxidizing Atmosphere)

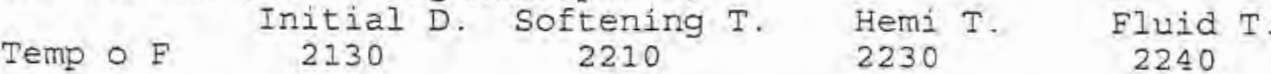

Apparent Specific Gravity ... 2.08

NOTE: Insufficient material to run HGI determination.

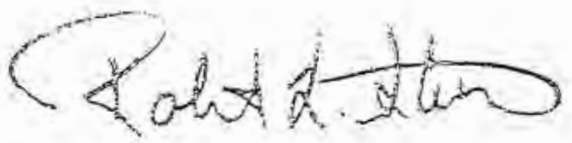

Robert I. Stull

Director of Coal Services 


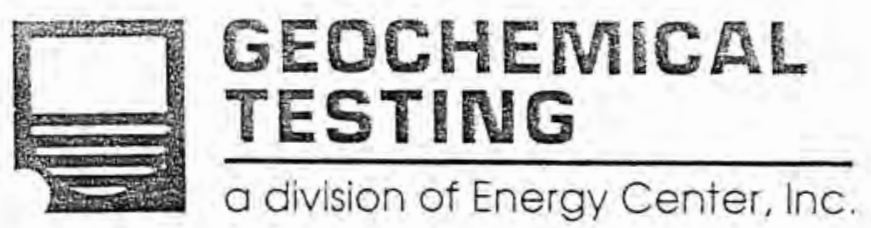

2005 N Center Ave Somerset PA 15501

814/443-1671

$814 / 445-6666$

FAX: $814 / 445-6729$

COAL ANALYSIS REPORT

Client: US GEOIOGICAI SURVEY-CO (MCHG)

Sampled by: E.R. Landis

Sampling Date: 01/26/1999

Aralyzed on: 02/04/1999

Description: Balinka Mine B2

LAB NO. 99-012903

Air Dry Loss.............. 14.84 \%

Residual Moisture........ $9.07 \%$

As Received Dry Dry Ash-Free

PROXIMATE ANALYSIS D3172

Moisture............ 22.56

Ash................. 17.50

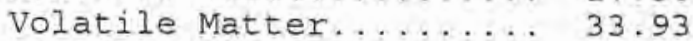

Fixed Carbon.......... 26.01

100.00

UITIMATE ANALYSIS

Hydrogen........D5373.. 5.77

Carbon..........D5373 . 41.17

Nitrogen.........D5373., 0.52

Sulfur..........D4239.. 4.16

Oxygen.......... D3176 . 30.88

Ash............ D3174.. 17.50

-.....

100.00

22.60

43.81

33.59

56.61

43.39

-...-

100.00

100.00

4.20

5.42

53.16

68.68

0.67

0.87

5.37

6.93

14.00

18.10

22.60

$\cdots \cdots$

100.00

100.00

Heating Value(BTU/Lb) D1989 7318

9449

12209

FORMS OF SULFUR D2492

Sulfate sulfur........ 0.03

Pyritic Sulfur.......... 0.51

Organic sulfur........ 3.62

0.04

0.66

0.85

4.68

6.04

Free Swelling Index D720

0.0

Equilibrium Moisture D1412-93

22.65

Hardgrove Grind. Index D409 


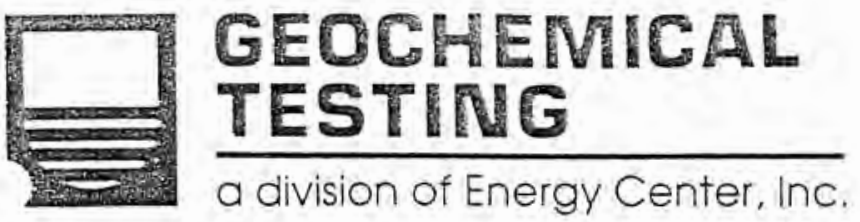

2005 N Center Ave Somerset PA 15501

814/443-1671

$814 / 445-6666$

FAX: $814 / 445-6729$

Client: US GEOLOGICAI SURVEY-CO (MCHG)

Sampled by: E.R. Landis

Sampling Date: 01/26/1999

Analyzed on: 02/04/1999

Description: Balinka Mine B2

L.AB NO. 99-012903

Ash Fusion (Reducing Atmosphere)

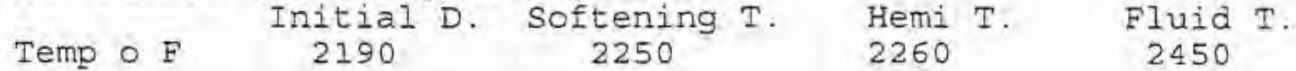

Ash Fusion (Oxidizing Atmosphere)

Initial D. Softening $T$.

$\begin{array}{lllll}\text { Temp O F } & 2250 & 2330 & 2410 & 2510\end{array}$

Apparent Specific Gravity .... 1.40 
2005 N Center Ave Somerset PA 15501

$814 / 443-1671$

$814 / 445-6666$

FAX: 814/445-6729

COAI ANALYSIS REPORT

Client: US GEOLOGICAL SURVEY-CO (MCHG)

Sampled by: E.R. Landis

Sampling Date: 01/26/1999

Analyzed on: 02/04/1999

Description: Balinka Mine

IAB NO. 99-012904

Air Dry Loss............. $15.90 \%$

Residual Moisture......... 10.14\%

As Received

Dry

Dry Ash-Free

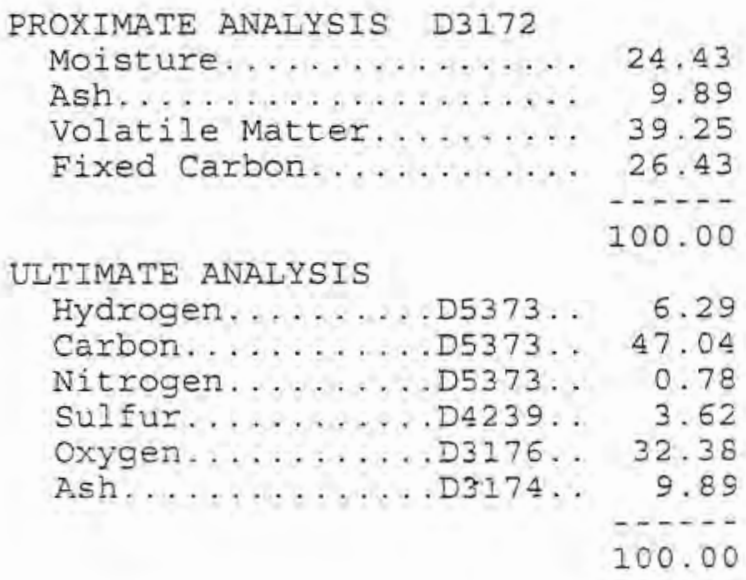

Heating Value (BTU/Lb) DI989 8419

FORMS OF SULEUR D D2492

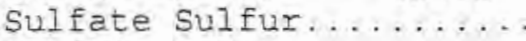

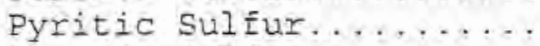

Organic sulfur..........

Free Swelling Index D720

Equilibrium Moisture D1412-93

Hardgrove Grind. Index D409
0.03

0.35

3. 24
13.09

51.94

34.97

…...

100.00

4.70

62.25

1.03

4.80

14.13

13.09

.......

100.00

11140

12818

0.03

0.04

0.47

0.54

4. 30

59.76

40.24

100.00

5.41

71.63

1.19

5. 52

16. 25

-.....

100.00
0.0

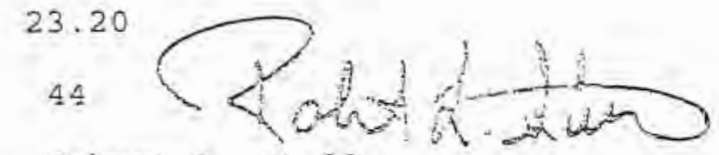

Robert I. Stull

Director of Coal Services 


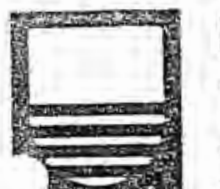

\section{GEOCHEMICAL \\ TESTING}

2005 N Center Ave Somerset PA 15501

814/443-1671

$814 / 445-6666$

FAX: 814/445-6729

COAI ANAIYSIS REPORT

Page: 2

Client: US GEOLOGICAI SURVEY-CO (MCHG)

Sampled by: E.R. Landis

Sampling Date: 01/26/1999

Analyzed on: $02 / 04 / 1999$

Description: Balinka Mine B3

LAB NO. 99-012904

Ash Fusion (Reducing Atmosphere)

$\begin{array}{ccccc}\text { Temp o F } & 2280 & \text { Softening } T . & \text { Hemi T. } & \text { Fluid T } \\ & 2370 & 2380 & 2470\end{array}$

Ash Fusion (Oxidizing Atmosphere)

Initial D. Softening $T$. Hemi T. Fluid $T$.

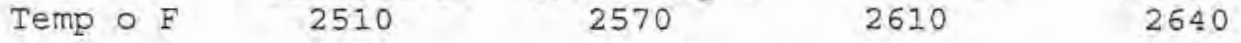

Apparent Specific Gravity .... 1.37 
2005 N Center Ave Somerset PA 15501

814/443-1671

$814 / 445-6666$

FAX: 814/445-6729

COAI ANALYSIS REPORT

Client: US GEOLOGICAL SURVEY-CO (MCHG)

Sampled by: E.R. Landis

Sampling Date: 01/26/1999

Analyzed on: 02/09/1999

Description: Balinka Mine B4

LAB NO. 99-013045

Air Dry Loss................. $19.15 \%$
Residual Moisture......... $7.15 \%$

As Received

Dry

Dry Ash-Free

PROXIMATE ANAIYSIS D3172

Moisture............ 24.93

Ash................. 9.85

Volatile Matter........ 36.54

Fixed Carbon........... 28.68

1......

ULTIMATE ANAIYSIS

100.00

Hydrogen.........D5373 . 6.13

Carbon.........D5373.. 46.06

Nitrogen........ D5373.. 0.80

Sulfur.........D D 239.. 4.16

Oxygen...........D3176.. 33.00

Ash...........D3174.. 9.85

-.....

100.00

13.12

$48.67 \quad 56.02$

$38.21 \quad 43.98$

-

100.00

100.00

4.45

5,12

61.36

70.62

1.07

5.55

1. 23

14.45

6.38

13.12

16.65

......

100.00

-.....

100.00

Heating Value (BTU/Lb) D1989 8125

10823

12457

FORMS OF SULFUR D2492

Sulfate sulfur.........

Pyritic sulfur..........

0.02

0.48

0.02

0.64

0.02

Organic sulfur......... 3.66

4.89

0.73

5.63

Free Swelling Index D720

0.5

Equilibrium Moisture D1412-93

Hardgrove Grind. Index D409

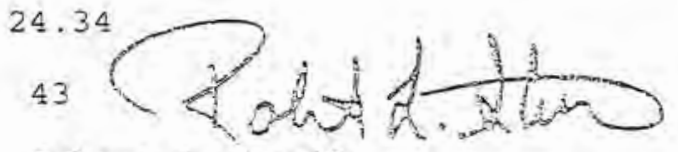

Robert I. Stull

Director of Coal Services 
2005 N Center Ave Somerset PA 15501

814/443-1671

814/445-6666

FAX: 814/445-6729

Client: US GEOLOGICAL SURVEY-CO (MCHG)

Sampled by: E.R. Landis.

Sampling Date: 01/26/1999

Analyzed on: 02/09/1999

Description: Balinka Mine B4

IAB NO. 99-013045

Ash Fusion (Reducing Atmosphere)

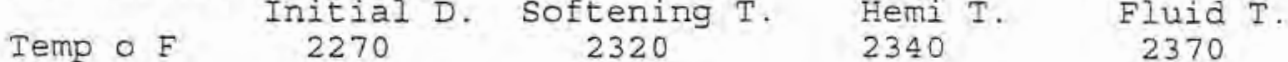

Ash Fusion (Oxidizing Atmosphere)

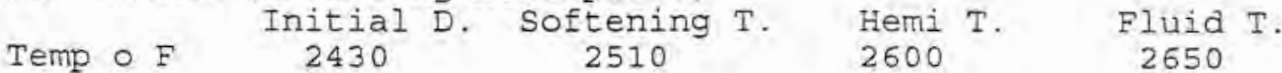

Apparent Specific Gravity ... $\quad 1.35$ 


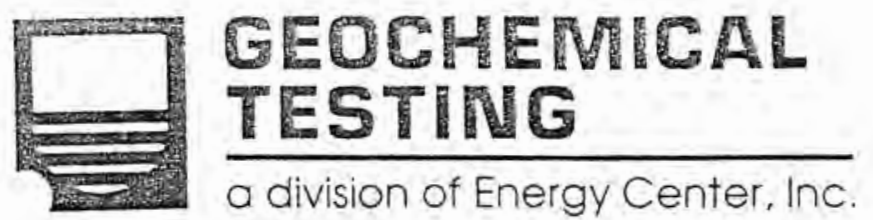

COAL ANALYSIS REPORT

Client: US GEOLOGICAL SURVEY-CO (MCHG)

Sampled by: E.R. Landis

Sampling Date: 01/26/1999

Analyzed on: 02/09/1999

Description: Balinka Mine B5

LAB NO. 99-013046

Air Dry Loss............ 17.23\%

Residual Moisture........ $9.57 \%$

As Received

Dry

Dry Ash-Free

PROXIMATE ANALYSIS D3172

Moisture........... 25.15

Ash................ 10.10

Volatile Matter........ 35.88

Fixed Carbon.......... 28.87

-......

ULTIMATE ANALYSIS

100.00

Hydrogen.........D5373 .. 6.07

Carbon,.........D5373 . 45.93

Nitrogen.........D5373 . 0.80

Sulfur.........D4239.. 4.15

oxygen, ........D3176, 32.95

A.sh..........D3174.. 10.10

-.....

100.00

Heating value (BTU/Lb) D1989 8132

FORMS OF SULFUR D2492

Sulfate sulfur......... 0.02

Pyritic sulfur......... 0.44

Organic sulfur........ 3.69

Free Swelling Index D720

Equilibrium Moisture D1412-93

Hardgrove Grind. Index D409

MEMBEF

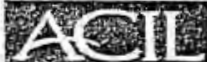

2005 N Center Ave Somerset PA 15501

$814 / 443-1671$

$814 / 445-6666$

FAX: 814/445-6729 


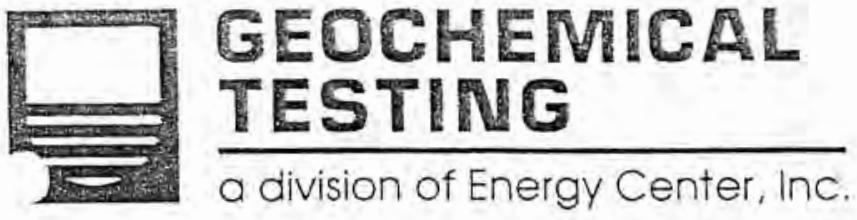

COAL ANALYSIS REPORT
2005 N Center Ave Somerset PA 15501

814/443-1671

$814 / 445-6666$

FAX: 814/445-6729

Client: US GEOLOGICAL SURVEY-CO (MCHG)

Sampled by: E.R. Landis

Sampling Date: 01/26/1999

Analyzed on: 02/09/1999

Description: Balinka Mine B5

LAB NO. 99-013046

Ash Fusion (Reducing Atmosphere)

Initial D. Softening $T$.

Ash Fusion (Oxidizing Atmosphere)

Initial D. Softening $T$. Hemi $T$. Fluid $T$.

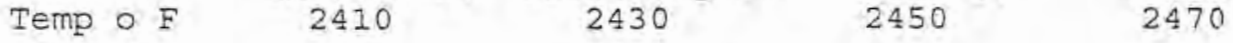

Apparent Specific Gravity ... 1.28

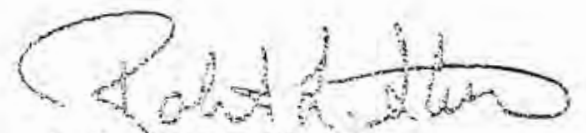


2005 N Center Ave Somerset PA 15501

814/443-1671 $814 / 445-6666$ FAX: 814/445-6729

COAI ANALYSIS REPORT

Client: US GEOLOGICAL SURVEY-CO (MCHG)

Sampled by: E.R. Landis

Sampling Date: 01/26/1999

Analyzed on: 02/09/1999

Description: Balinka Mine B6

LAB NO. 99-013047

Air Dry Loss..............16.83\%

Residual Moisture........ $6.18 \%$

As Received

Dry

Dry Ash-Free

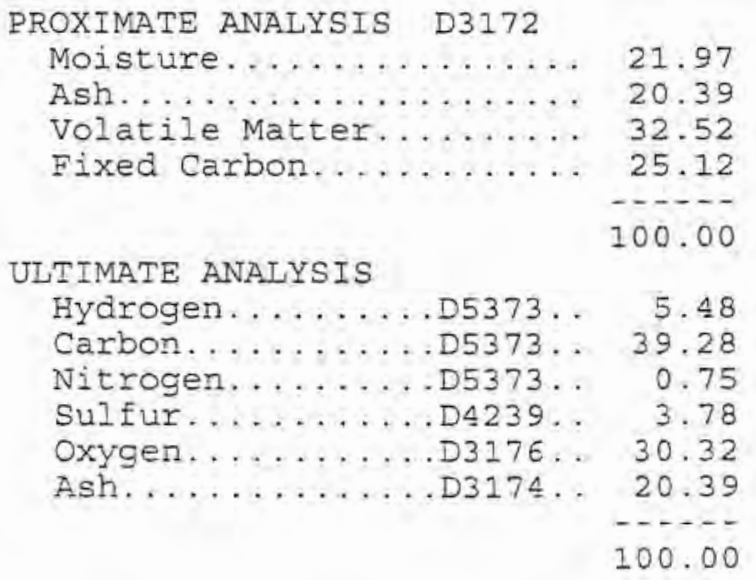

Heating Value(BTU/Lb) D1989 6973

FORMS OF SULFUR D2492

Sulfate sulfur..........

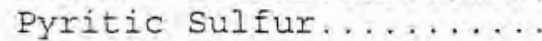

Organic sulfur..........

Free Swelling Index D720

Equilibrium Moisture D1412-93

Hardgrove Grind. Index D409
0.02

0.72

3.04
26.14

41.68

32.18

-....

100.00

3.87

50.34

0.96

4.85

13.84

26.14

-.....

100.00

8936

12098

0.03

0.92

3.90

0.04

1. 24

5. 29

56.42

43.58

100.00

5.24

68.15

1. 30

6.57

18.74

.......

100.00
0.5
20.97

37
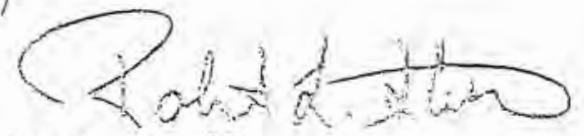

Robert I, Stull

Director of Coal Services 
2005 N Center Ave Somerset PA 15501

814/443-1671

$814 / 445-6666$

FAX: 814/445-6729

COAI ANALYSIS REPORT

Client: US GEOLOGICAI SURVEY-CO (MCHG)

Sampled by: E.R. Iandis

Sampling Date: 01/26/1999

Analyzed on: 02/09/1999

Description: Balinka Mine B6

LAB NO. 99-013047

Ash Fusion (Reducing Atmosphere)

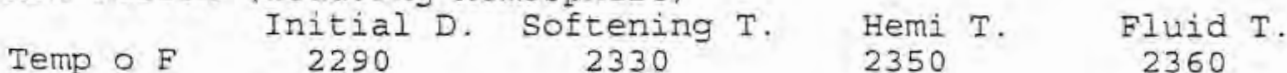

Ash Fusion (Oxidizing Atmosphere)

Initial D. Softening $T$.

Apparent Specific Gravity .... 1.44

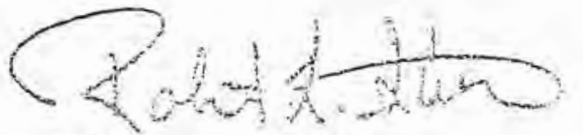

Robert I. Stuli

Director of Coal Services 

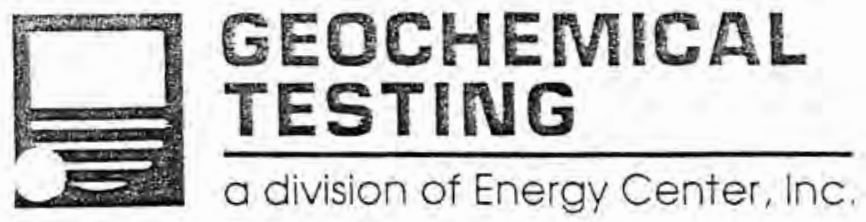

2005 N Center Ave Somerset PA 15501

814/443-1671

$814 / 445-6666$

FAX: 814/445-6729

COAL ANALYSIS REPORT

Client: US GEOLOGICAI SURVEY-CO (MCHG)

Sampled by: E.R. Landis

Sampling Date: 12/17/98 To $12 / 17 / 98$

Analyzed on: $01 / 02 / 99$

Description: Putnok Mine P2

LAB NO. 99-012108

Air Dry Loss............. $22.82 \%$
Residual Moisture........ $6.13 \%$

As Received

Dry

Dry Ash-Free

PROXIMATE ANALYSIS D3172

Moisture........... 27.55

Ash.................. 15.00

Volatile Matter........ 30.10

Fixed Carbon.......... 27.35

-.....

ULTIMATE ANALYSIS

100.00

Hydrogen........D5373..6.6.05

Carbon..........D5373.. 39.64

Nitrogen.........D5373.. 0.79

Sulfur.......... D4239.. 2.25

Oxygen.........D3176... 36.27

Ash...........D3174.. 15.00

100.00

20.70

41.55

37.75

52.39

47.61

…...

100.00

100.00

4. 10

54.71

1.09

3. 11

16.29

20.70

.......

100.00

100.00

5.16

69.00

1. 37

3. 92

20.55

.......

100.00

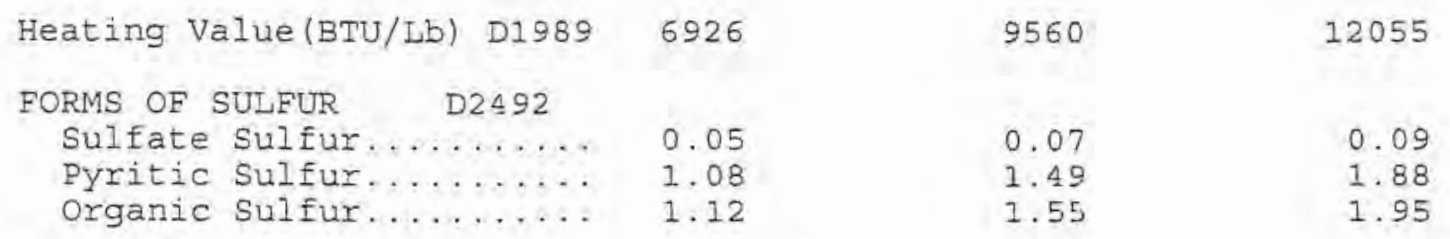

Eree Swelling Index D720

0.0

Equilibrium Moisture D1412-93

27.21

Hardgrove Grind. Index D409

41

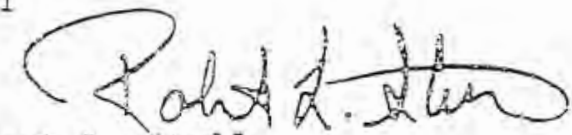

Robert I. Stull

Director of Coal Services 


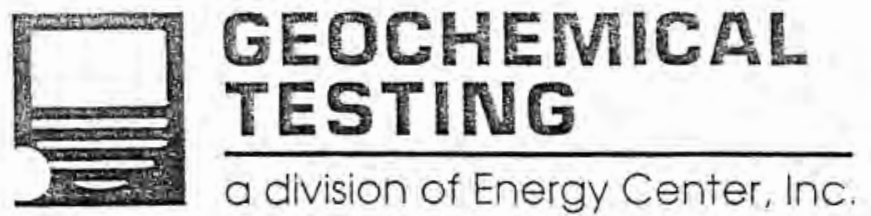

\author{
2005 N Center Ave \\ Somerset PA 15501 \\ $814 / 443-1671$ \\ $814 / 445-6666$ \\ FAX: 814/445-6729
}

COAI ANALYSIS REPORT

Page: 2

Client: US GEOLOGICAI SURVEY-CO (MCHG)

Sampled by: E.R. Landis

Sampling Date: $12 / 17 / 98$ TO $12 / 17 / 98$

Analyzed on: $01 / 02 / 99$

Description: Putnok Mine P2

LAB NO. 99-012108

Ash Fusion (Reducing Atmosphere)

$\begin{array}{ccccc} & \text { Initial D. } & \text { Softening T. } & \text { Hemi T. } & \text { Fluid T. } \\ \text { Temp o } & 2190 & 2300 & 2350\end{array}$

Ash Eusion (Oxidizing Atmosphere)

Initial D. Softening T. Hemi T. Fluid T.

Temp OF $2360 \quad 2380$

$2410 \quad 2490$

Apparent Specific Gravity .... $\quad 1.32$

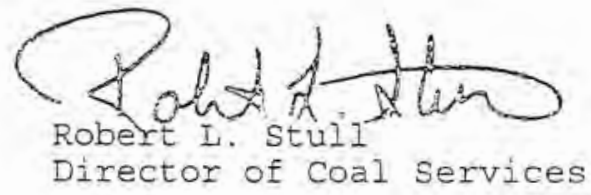


2005 N Center Ave Somerset PA 15501

814/443-1671

$814 / 445-6666$

FAX: 814/445-6729

COAL ANAIYSIS REPORT

Client: US GEOLOGICAL SURVEY-CO (MCHG)

Sampled by: E.R. Landis

Sampling Date: 12/17/98 TO $12 / 17 / 98$

Analyzed on: 01/02/99

Description: Putnok Mine P4

IAB NO. 99-012109

Air Dry Loss............. $20.42 \%$
Residual Moisture.......... $9.22 \%$

As Received

Dry

Dry Ash-Eree

PROXIMATE ANALYSIS D3172

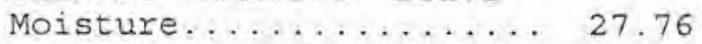

Ash................. 13.11

Volatile Matter....... 30.49

Fixed Carbon........... 28.64

-.....

ULTIMATE ANAIYSIS

100.00

Hydrogen........D5373.. 6.01

Carbon..........D5373.. 40.85

Nitrogen.........D5373 .. 0.84

Sulfur...........D4239.. 3.21

Oxygen.......... D3176.. 35.98

Ash..........D3174,. 13.11

-.....

100.00

18.14

42.20

39.66

......

100.00

48.45

$\ldots . . .$.

100.00

4. 02

56.55

1. 16

4. 45

15.68

18.14

100.00

4. 91

69.09

1. 41

5. 44

19.15

100.00

Heating Value (BTU/Lb) D1989 7045

9752

11914

FORMS OF SULFUR D2492

Sulfate sulfur................ 0.06

Pyritic Sulfur.......... 1.47

Organir sulfur......... 1.68

0.09

0.11

2. 04

2. 49

2.32

2. 84

Free Swelling Index D720

0.0

Equilibrium Moisture D1412-93

Hardgrove Grind. Index D409

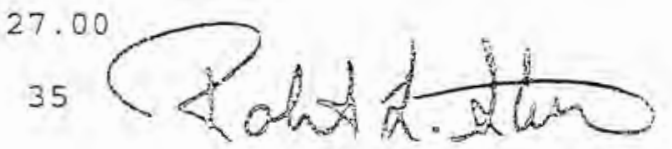

Robert I. Stull

Director of Coal Services 


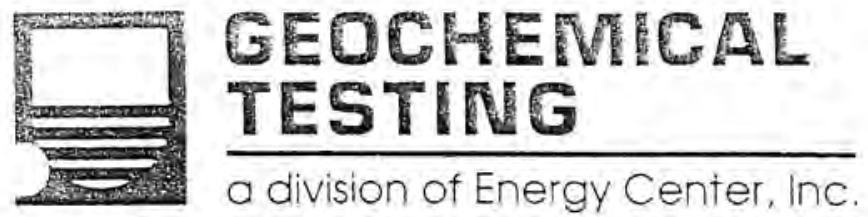

2005 N Center Ave Somerset PA 15501

814/443-1671

$814 / 445-6666$

FAX: 814/445-6729

COAL ANAIYSIS REPORT

Page:

2

Client: US GEOLOGICAI SURVEY-CO (MCHG)

Sampled by: E.R. Landis

Sampling Date: 12/17/98 TO 12/17/98

Analyzed on: 01/02/99

Description: Putnok Mine P4

LAB NO. 99-012109

Ash Fusion (Reducing Atmosphere)

$\begin{array}{ccccc} & \text { Initial D. Softening } & \text { S. Hemi T. } & \text { Fluid T. } \\ \text { Temp o } E & 2040 & 2060 & 2070 & 2080\end{array}$

Ash Fusion (Oxidizing Atmosphere)

Initial D. Softening $T$. Hemi $T$. Fluid $T$.

Apparent Specific Gravity .... 1.37

$2240 \quad 2250$

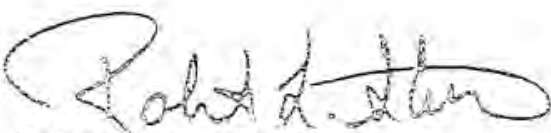


Client: US GEOLOGICAI SURVEY-CO (MCHG)

Sampled by: E.R. Landis

Sampling Date: 12/17/98 To 12/17/98

Analyzed on: $01 / 02 / 99$

Description: Putnok Mine P6

LAB NO. 99-012110

Air Dry Loss............. $17.36 \%$
Residual Moisture........ $10.22 \%$

As Received

Dry

Dry Ash-Free

PROXIMATE ANALYSIS D3172

Moisture,............ 25.81

Ash .................. 18.31

Volatile Matter......... 29.18

Fixed Carbon........... 26.70

24.68

39.33

35.99

52.22

......

ULTIMATE ANALYSIS

100.00

100.00

47.78

100.00

Hydrogen......... D5373 .. 5.78

Carbon..........D5373.. 37.95

Nitrogen........D5373 .. 0.64

Sulfur......... D4239.. 3.26

oxygen..........D3176.. 34.06

Ash............D3174.. 18.31

100.00

3.89

51.16

0.87

4.40

15.00

24.68

-......

100.00

5.17

67.92

1.15

5.84

19.92

100.00

Heating Value(BTU/Lb) D1989 6577

8865

11771

FORMS OF SULFUR D2492

Sulfate Sulfur......... 0.05

Pyritic Sulfur.......... 1.11

Organic sulfur......... 2.10

0.07

0.09

1. 49

1. 98

Free Swelling Index D720

0.0

Equilibrium Moisture D1412-93

Hardgrove Grind. Index D409

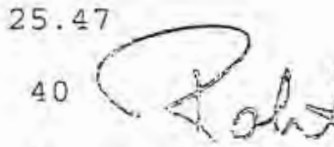

Robert I, Stull

Director of Coal Services 


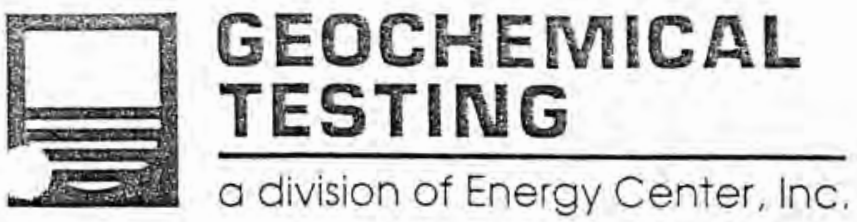

2005 N Center Ave Somerset PA 15501

814/443-1671

$814 / 445-6666$

FAX: 814/445-6729

COAI ANALYSIS REPORT

Client: US GEOLOGICAI SURVEY-CO (MCHG)

Sampled by: E.R. Landis

Sampling Date: 12/17/98 To 12/17/98

Analyzed on: 01/02/99

Description: Putnok Mine PG

IAB NO. 99-012110

Ash Fusion (Reducing Atmosphere)

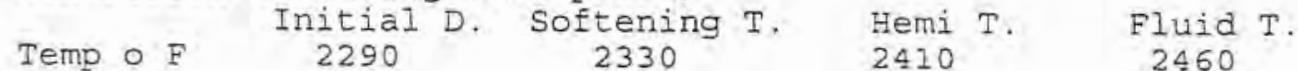

Ash Fusion (Oxidizing Atmosphere)

Temp o F $\begin{array}{ccccr}\text { Initial D. Softening } T . & \text { Hemi } T . & \text { Fluid } T \text {. } \\ 2420 & 2440 & 2480 & 2520\end{array}$

Apparent Specific Gravity .... 1.35 
2005 N Center Ave Somerset PA 15501

814/443-1671 $814 / 445-6666$

FAX: 814/445-6729

COAL ANAIYSIS REPORT

Client: US GEOLOGICAL SURVEY-CO (MCHG)

Sampled by: E.R. Landis

Sampling Date: $12 / 16 / 98$ TO $12 / 16 / 98$

Analyzed on: $12 / 31 / 98$

Description: Visonta East II Mine Sample VI

LAB NO. $98-012010$

Air Dry Loss........... 45.25 \%

As Received

Dry

Dry Ash-Eree

PROXIMATE ANALYSIS D3172

Moisture............ 48.17

Ash.................. 15.17

Volatile Matter........ 22.55

Fixed Carbon............ 14.11

-.....

ULTIMATE ANAIYSIS

100.00

Hydrogen..........D5373.. 7.42

Carbon..........D5373 .. 24.36

Nitrogen.........D5373 . 0.39

Sulfur.........D4239.. 1.35

Oxygen..........D3176.. 51.31

Ash...........D3174.. 15.17

-.....

100.00

29.26

Heating Value(BTU/Lb) D1989 4239

D2492

FORMS OF SULEUR

0.08

Sulfate Sulfur..........

Pyritic Sulfur...........

Organic sulfur.........

0.71

0.56

Free Swelling Index D720

Equilibrium Moisture D1412-93

MEMEER

43.50

27.24

…...

100.00

3.92

47.00

0.76

2. 61

16.45

29.26

-......

100.00

8178

11561
0.5

44.37

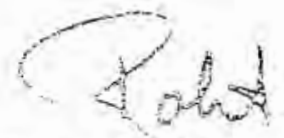

0.16

1. 36

1.09

0.22

1.93

1.54
6.1 .50

38.50

100.00

5.54

66.44

1.08

3. 69

23.25

100.00

Robert I. Stull

Director of coal services 
2005 N Center Ave Somerset PA 15501

$814 / 443-1671$

$814 / 445-6666$

FAX: 814/445-6729

Client: US GEOLOGICAL SURVEY-CO (MCHG)

Sampled by: E.R. Landis

Sampling Date: 12/16/98 To 12/16/98

Analyzed on: $12 / 31 / 98$

Description: Visonta East II Mine Sample V1

LAB NO. 98-012010

Ash Fusion (Reducing Atmosphere)

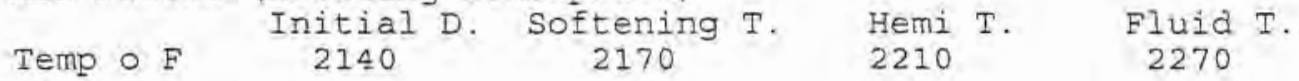

Ash Fusion (Oxidizing Atmosphere)

Initial D. Softening $T$. Hemi $T$. Fluid $T$.

$\begin{array}{lllll}\text { Temp } \circ \mathrm{F} & 2250 & 2270 & 2310 & 2350\end{array}$

Apparent Specific Gravity .... 1.11

NOTE: Insufficient materiai to run HGI. 
2005 N Center Ave Somerset PA 15501

814/443-1671

$814 / 445-6666$

FAX: 814/445-6729

COAL ANALYSIS REPORT

Client: US GEOLOGICAL SURVEY-CO (MCHG)

Sampled by: E.R. Landis

Sampling Date: $12 / 16 / 98$ To $12 / 16 / 98$

Analyzed on: $12 / 31 / 98$

Description: Visonta East II Mine Sample V2

LAB NO. 98-012011

Air Dry Loss............. $44.90 \div$
Residual Moisture......... $6.35 \div$

As Received.

Dry

Dry Ash-Eree

PROXIMATE ANALYSIS D3172

Moisture............ 48.40

Ash................. 9.42

Volatile Matter......... 25.64

Fixed Carbon.......... 16.54

(2.....

ULTIMATE ANALYSIS

100.00

Hydrogen.........D5373.. 7.63

Carbon..........D5373.. 27.44

Nitrogen.........D5373 .. 0.42

Sulfur.........D4239.. 2.10

oxygen.........D3176,. 52.99

Ash . . . . . . D D 174 . 9.42

18.26

$\begin{array}{ll}49.68 & 60.78\end{array}$

$32.06 \quad 39.22$

…...

100.00

-.....

100.00

4.28

5. 24

53.19

65.07

0.81

4.07

0.99

4. 98

19.39

23.72

18.26

100.00

100.00

100.00

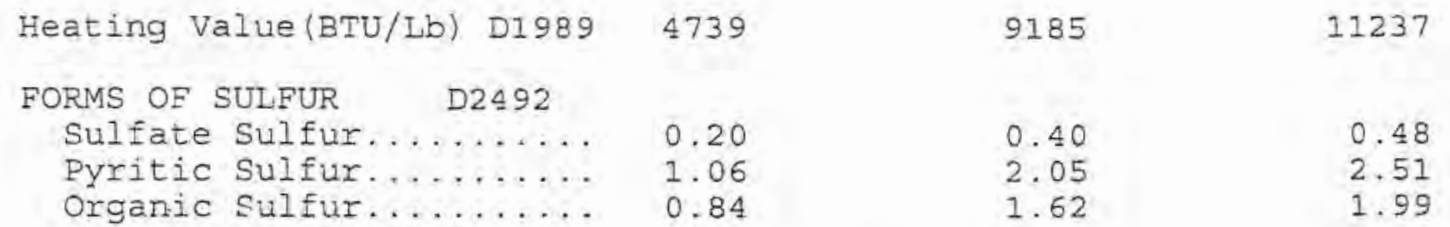

Free Swelling Index D720

Equilibrium Moisture D1412-93

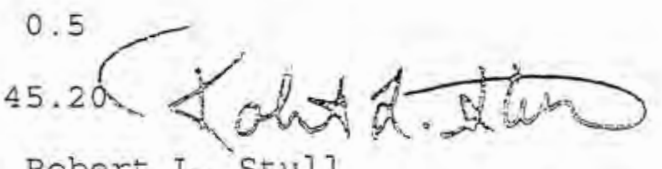

Robert I. Stull

Director of coal Services 


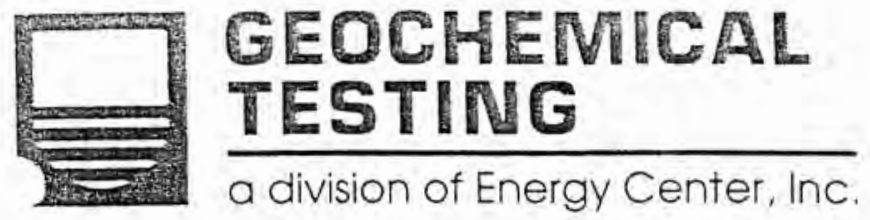

COAL ANALYSIS REPORT
2005 N Center Ave Somerset PA 15501

$814 / 443-1671$

814/445-6666

FAX: 814/445-6729

Client: US GEOLOGICAI SURVEY-CO (MCHG)

Sampled by: E.R. Landis

Sampling Date: 12/16/98 TO $12 / 16 / 98$

Analyzed on: $12 / 31 / 98$

Description: Visonta East II Mine Sample V2

LAB NO. 98-012011

Ash Fusion (Reducing Atmosphere)

Temp o F $\quad \begin{array}{ccccc}\text { Initial D. Softening } T . & \text { Hemi T. } & \text { Fluid T. } \\ 2170 & 2180 & 2180 & 2210\end{array}$

Ash Fusion (Oxidizing Atmosphere)

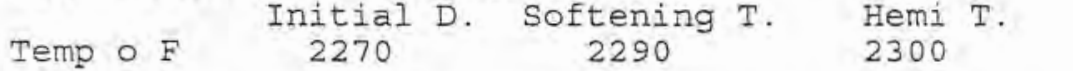

Apparent Specific Gravity ... 0.97

NOTE: Insufficient material to run HGI.

Page: 2 
2005 N Center Ave Somerset PA 15501

$814 / 443-1671$

814/445-6666

FAX: 814/445-6729

COAI ANALYSIS REPORT

Client: US GEOLOGICAL SURVEY-CO (MCHG)

Sampled by: E.R. Iandis

Sampling Date: 12/16/98 To $12 / 16 / 98$

Analyzed on: $12 / 31 / 98$

Description: Visonta East II Mine Sample V3

ILAB NO. 98-012012

Air Dry Loss............... $37.10 \div$
Residual Moisture... . . . . . $4.10 \%$

As Received

Dry

Dry Ash-Free

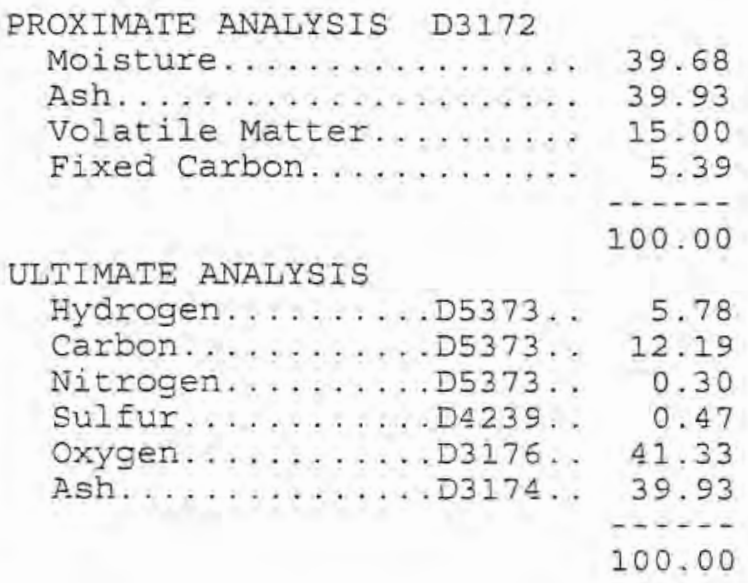

Heating Value (BTU/Ib) D1989 2109

FORMS OF SULFUR D2492

Sulfate Sulfur........ 0.03

Pyritic sulfur..........

Organic sulfur..........

Free Swelling Index D720

Equilibrium Moisture D1412-93

$M E M B E R$

0.19

0.25
66.20

24.86

8.94

.......

100.00

2. 22

20.21

0.50

0.78

10.09

66.20

-.....

100.00

3497

10346

0.05

0.15

0.31

0.93

0.42

1. 23

$$
\begin{array}{r}
73.56 \\
26.44 \\
100.00 \\
6.58 \\
59.80 \\
1.48 \\
2.31 \\
29.83 \\
\\
100.00
\end{array}
$$

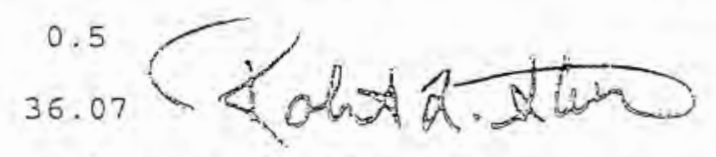

Robert I. Stull

Director of Coal Services 


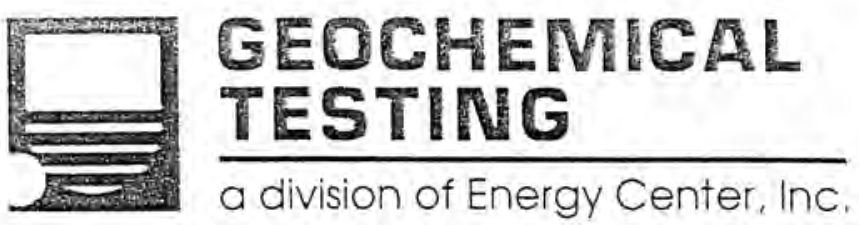

2005 N Center Ave Somerset PA 15501

814/443-1671

814/445-6666

FAX: 814/445-6729

COAL ANALYSIS REPORT

Page: 2

Client: US GEOLOGICAI SURVEY-CO (MCHG)

Sampled by: E.R. Iandis

Sampling Date: $12 / 16 / 98$ TO $12 / 16 / 98$

Analyzed on: 12/31/98

Description: Visonta East II Mine Sample V3

IAB NO. 98-012012

Ash Fusion (Reducing Atmosphere)

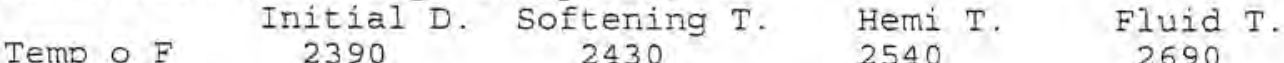

Ash Fusion (Oxidizing Atmosphere)

Temo o $\quad \begin{array}{cccc}\text { Initial D. Softening } T . & \text { Hemi } T . & \text { Fluid } T \text {. } \\ 2540 & 2620 & 2700 & 2750\end{array}$

Apparent Specific Gravity .... 1.20

NOTE: Insufficient material to run HGI. 

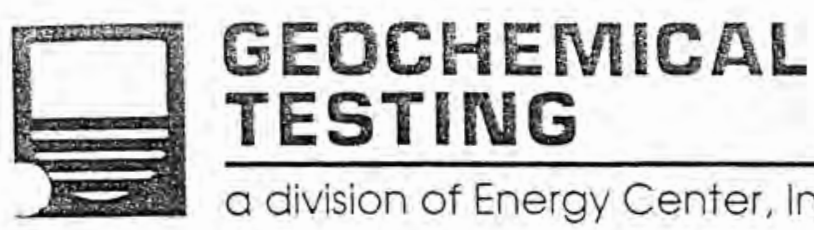

2005 N Center Ave Somerset PA 15501

$814 / 443-1671$

814/445-6666

FAX: 814/445-6729

COAL ANAIYSIS REPORT

Client: US GEOLOGICAL SURVEY-CO (MCHG)

Sampled by: E.R. Landis

Sampling Date: 12/16/98 To $12 / 16 / 98$

Analyzed on: $12 / 31 / 98$

Description: Visonta East II Mine Sample V4

IAB NO. 98-012013

Air Dry Loss.............. $44.14 \%$
Residual Moisture......... $6.66 \%$

As Received

Dry

Dry Ash-Free

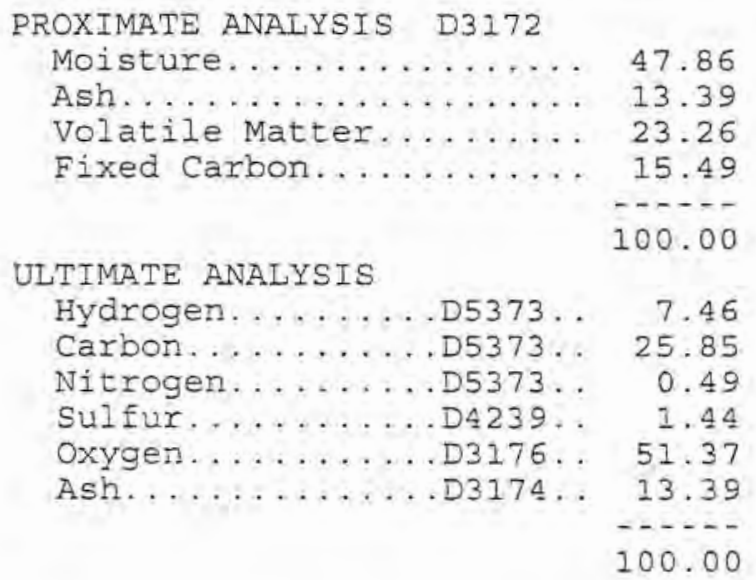

25.68

44.61

29.71

.......

100.00

4.04

49.58

2.76

17.01

25.68

......

100.00

Heating Value(BTU/Lb) D1989 4522

FORMS OF SULFUR D2492

Sulfate Sulfur......... 0.09

Pyritic Sulfur......... 0.57

organic sulfur......... 0.78

Free Swelling Index D720

Equilibrium Moisture D1412-93

MEMBER

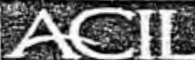

0.93

8672

11669

60.03

39.97

.......

100.00

5.44

66.71

1. 25

3.72

22.88

-.....

100.00

0.25

I. 47

1.18

1. 49

2. 00 


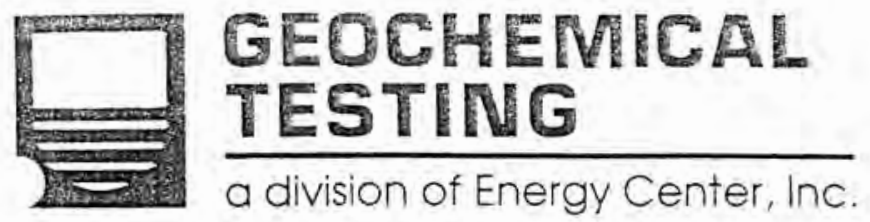

2005 N Center Ave Somerset PA 15501

814/443-1671

$814 / 445-6666$

FAX: 814/445-6729

Client: US GEOLOGICAL SURVEY-CO (MCHG)

Sampled by: E.R. Landis

Sampling Date: 12/16/98 TO $12 / 16 / 98$

Analyzed on: $12 / 31 / 98$

Description: Visonta East II Mine Sample V4

IAAB NO. $98-012013$

Ash Fusion (Reducing Atmosphere)

Temp $O F$ Initial D. Softening $T$. Hemi $T$. Fluid $T$.

Ash Fusion (Oxidizing Atmosphere)

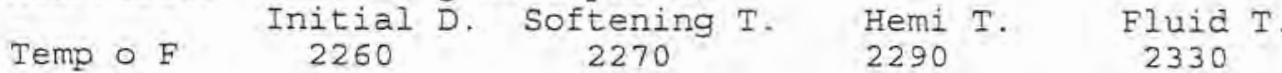

Apparent Specific Gravity .... $\quad 1.02$

NOTE: Insufficent material to run HGI. 
2005 N Center Ave Somerset PA 15501

814/443-1671 814/445-6666 FAX: 814/445-6729

COAL ANALYSIS REPORT

Client: US GEOLOGICAL SURVEY-CO (MCHG)

Sampled by: E.R. Landis

Sampling Date: 12/16/98 TO 12/16/98

Aralyzed on: $12 / 31 / 98$

Description: Visonta East II Mine Sample V5

LAB NO. 98-012014

Air Dry Loss............. $33.98 \%$
Residual Moisture... . . . . $4.04 \%$

As Received

Dry

Dry Ash-Free

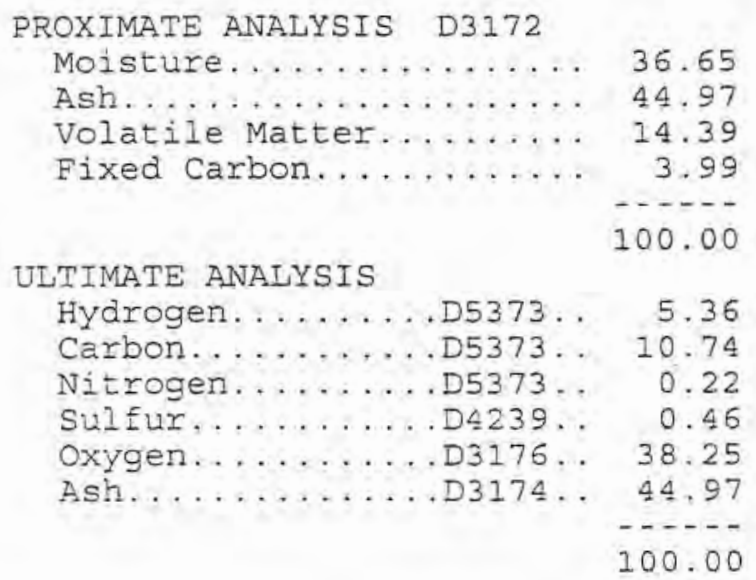

70.99

22.72

6.29

78.30

21.70

…...

100.00

100.00

1.99

6.85

16.95

58.44

0.35

0.73

8.99

1. 22

2. 51

30.98

70.99

100.00

100.00

\begin{tabular}{|c|c|c|c|}
\hline Heating Value (BTU/Ib) D1989 & 1827 & 2884 & 9940 \\
\hline FORMS OF SULFUR & & & \\
\hline Sulfate sulfur.......... & 0.04 & 0.06 & 0.22 \\
\hline Pyritic sulfur.......... & 0.21 & 0.33 & 1.15 \\
\hline organic sulfur.......... & 0.21 & 0.34 & 1.14 \\
\hline
\end{tabular}

Free Swellirig Index D720

Equilibrium Moisture D1412-93

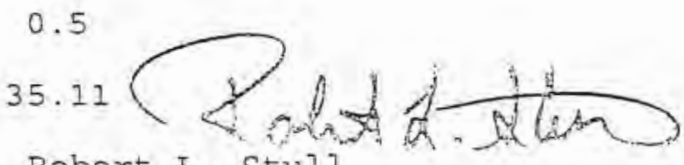

Robert L. Stull

Director of Coal Services

$M E M B E R$

A $A$ \% 


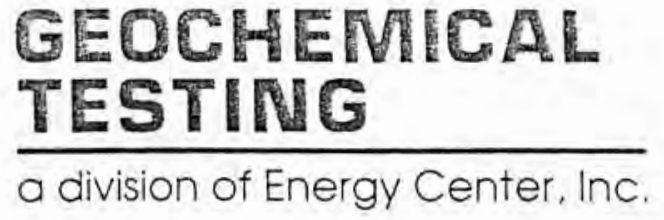

COAL ANALYSIS REPORT

Client: US GEOLOGICAL SURVEY-CO (MCHG)

Sampled by: E.R. Landis

Sampling Date: 12/16/98 To $12 / 16 / 98$

Analyzed on: $12 / 31 / 98$

Description: Visonta East II Mine Sample V5

LAB NO. 98-012014

Ash Fusion (Reducing Atmosphere)

Initial D. Softenirg

Temp o F 2380 2400

Ash Fusion (Oxidizing Atmosphere)

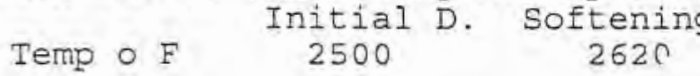

Apparent Specific Gravity .... 1.41

NOTE: Insufficient material to run HGI.
2005 N Center Ave Somerset PA 15501

$814 / 443-1671$

$814 / 445-6666$

FAX: 814/445-6729

Page: 2 
2005 N Center Ave Somerset PA 15501

814/443-1671

814/445-6666

FAX: 814/445-6729

COAL ANALYSIS REPORT

Client: US GEOLOGICAI, SURVEY-CO (MCHG)

Sampled by: E.R. Landis

Sampling Date: $12 / 16 / 98$ TO $12 / 16 / 98$

Analyzed on: 12/31/98

Description: Visonta East II Mine Sample V6

LAB NO. 98-012015

Air Dry Loss........... $41.54 \div$
Residual Moisture........ $5.80 \div$

As Received

Dry

Dry Ash-Free

PROXIMATE ANALYSIS D3172

Moisture............. 44.93

Ash .................. 15.38

Volatile Matter........ 24.89

Fixed Carbon........... 14.80

100.00

ULTIMATE ANALYSIS

7.21

Carbon............. $55373 \ldots 26.32$

Nitrogen.........D5373 .. 0.50

Sulfur......... D4239 . 1.78

Oxygen..........D3176.. 48.81

Ash..........D3174 .. 15.38

$10 . . .$.

100.00

27.93

45.20

26.87

62.72

37.28

-.....

......

100.00

100.00

3.97

5.51

47.80

0.90

3. 23

16.17

27.93

......

100.00

66.33

1. 25

4. 48

22.43

......

100.00

Heating Value (BTU/Lb) D1989 4577

8312

11533

FORMS OF SULFUR D2492

Sulfate sulfur...........

0.14

Pyritic sulfur..........

0.91

0.25

1. 66

0.35

Organic sulfur..........

0.73

1. 32

2. 30

1.83

Free Swelling Index D720

Equilibrium Moisture D1412-93

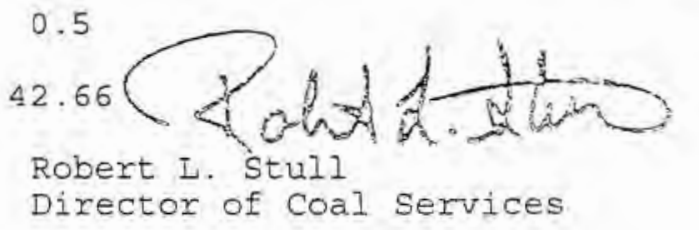




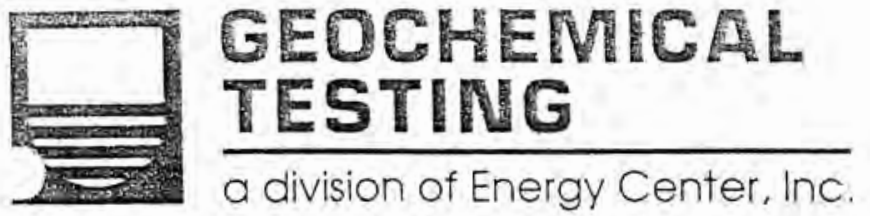

COAI ANALYSIS REPORT
2005 N Center Ave
Somerset PA 15501

$814 / 443-1671$

$814 / 445-6666$

FAX: 814/445-6729

Client: US GEOLOGICAI SURVEY-CO (MCHG)

Sampled by: E.R. Landis

Sampling Date: 12/16/98 TO 12/16/98

Analyzed on: $12 / 31 / 98$

Description: Visonta East II Mine Sample V6

LAB NO. 98-012015

Ash Fusion (Reducing Atmosphere)

Temp of $\begin{array}{ccccr}\text { Initial D. } & \text { Softening } T . & \text { Hemi } T . & \text { Fluid } T \text {. } \\ 2080 & 2120 & 2140 & 2160\end{array}$

Ash Fusion (Oxidizing Atmosphere)

Initial D. Softening $T$.

Apparent Specific Gravity .... 1.06

NOTE: Insufficient material to run HGI.

Page: 2 

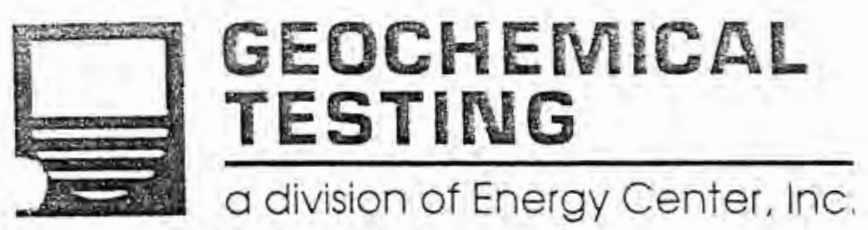

2005 N Center Ave Somerset PA 15501

$814 / 443-1671$

$814 / 445-6666$

COAL ANALYSIS REPORT

Client: US GEOLOGICAI SURVEY-CO (MCHG)

Sampled by: E.R. Landis

Sampling Date: 12/16/98 To 12/16/98

Analyzed on: $12 / 31 / 98$

Description: Visonta East II Mine Sample V7

LAB NO. $98-012016$

Air Dry Loss............ $32.04 \quad \%$

Residual Moisture........ 4.69 \%

As Received

PROXIMATE ANALYSIS D3172

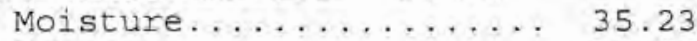

Ash ................ 52.06

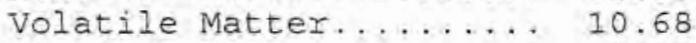

Fixed Carbon........... 2.03

-.....

ULTIMATE ANAIYSIS

100.00

Hydrogen.........D5373 . 4.99

Carbon...........D5373.. 6.36

Nitrogen.........D5373.. 0.15

Sulfur.........D4239.. 0.29

oxygen.........D3176.. 36.15

Ash...........D3174 . 52.06

-......

100.00

Dry

Dry Ash-Free

80.38

16.48

3. 14

…...

100.00

1. 62

9.82

0.23

0.44

7. 51

80.38

-......

100.00

FAX: 814/445-6729 
2005 N Center Ave Somerset PA 15501

$814 / 443-1671$

$814 / 445-6666$

FAX: $814 / 445-6729$

COAL ANALYSIS REPORT

Page: 2

Client: US GEOLOGICAL SURVEY-CO (MCHG)

Sampled by: E.R. Landis

Sampling Date: 12/16/98 TO 12/16/98

Analyzed on: 12/31/98

Description: Visonta Bast II Mine Sample V7

LAB NO. 98-012016

Ash Fusion (Reducing Atmosphere)

$\begin{array}{ccccc} & \text { Initial D. } & \text { Softening } T . & \text { Hemi T. } & \text { Fluid T. } \\ \text { Temp o } & 2430 & 2480 & 2530 & \end{array}$

Ash Fusion (Oxidizing Atmosphere)

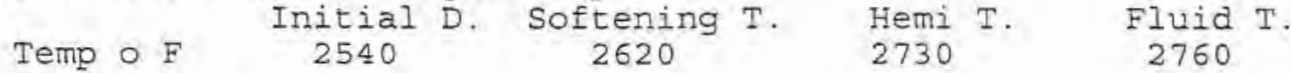

Apparent Specific Gravity .... 1.54

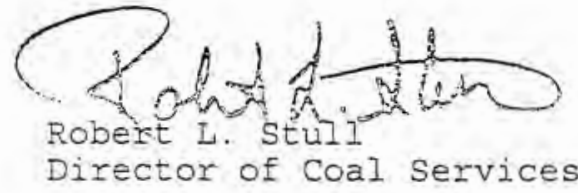


2005 N Center Ave Somerset PA 15501

814/443-1671

$814 / 445-6666$

FAX: $814 / 445-6729$

COAL ANAIYSIS REPORT

Client: US GEOLOGICAI SURVEY-CO (MCHG)

Sampled by: E.R. Landis

Sampling Date: $12 / 16 / 98$ TO $12 / 16 / 98$

Analyzed on: $12 / 31 / 98$

Description: Visonta East II Mine Sample V8

LAB NO. 98-012017

Air Dry Loss............ $40.88 \%$
Residual Moisture........ $5.86 \%$

As Received

Dry

Dry Ash-Free

PROXIMATE ANALYSIS D3172

Moisture............ 44.34

Ash .................. 21.65

Volatile Matter.................. 22.

Fixed Carbon............ 11.91

-.....

ULTIMATE ANALYSIS

100.00

Hydrogen........D5373 . 6.93

Carbon..........D5373.. 22.31

Nitrogen, ........D5373 .. 0.43

Sulfur.........D4239.. 1.09

Oxygen..........D3176.. 47.59

Ash............D3174.. 21.65

-...-

100.00

38.89

39.71

21.40

-....

100.00

3. 54

40.09

0.78

1. 97

14.73

38.89

.......

100.00

7005

0.16

0.78

1.03

0.09

$\begin{array}{ll}\text { Pyritic Sulfur........... } & 0.43 \\ \text { Organic sulfur.......... } & 0.57\end{array}$

$\begin{array}{lll}\text { Pyritic Sulfur........... } & 0.43 \\ \text { Organic Sulfvr........... } & 0.57\end{array}$

0.5

Equilibrium Moisture DI412-93

Hardgrove Grind. Index D\&09

MEMBER

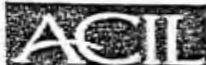

Free Swelling Index D720

Robert L. Stull
64.97

35.03

…....

100.00

5.80

65.60

1. 27

3.22

24.11

100.00

11462

0.26

1. 27

1.69

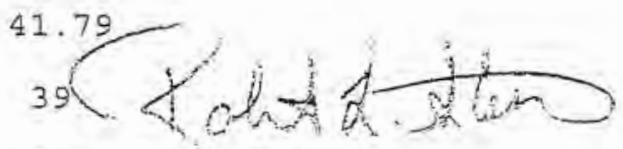

Director of Coal Services 


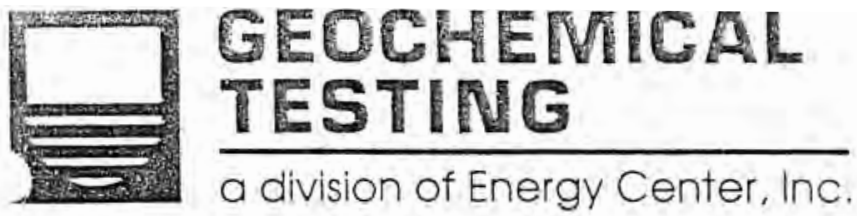

COAL ANALYSIS REPORT
2005 N Center Ave Somerset PA 15501

814/443-1671

814/445-6666

FAX: 814/445-6729

Client: US GEOLOGICAL SURVEY-CO (MCHG)

Sampled by: E.R. Iandis

Sampling Date: 12/16/98 TO $12 / 16 / 98$

Analyzed on: $12 / 31 / 98$

Description: Visonta East II Mine Sample V8

IAB NO. 98-012017

Ash Fusion (Reducing Atmosphere)

$\begin{array}{ccccc}\text { Temp o } & \text { Initial D. Softening T. } & \text { Hemi } & \text { T. } & \text { Fluid T. } \\ 2200 & 2150 & 2280 & 220\end{array}$

Ash Eusion (Oxidizing Atmosphere)

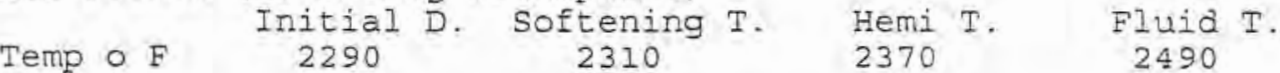

Apparent Specific Gravity .... $\quad 1.16$

Page: 2 


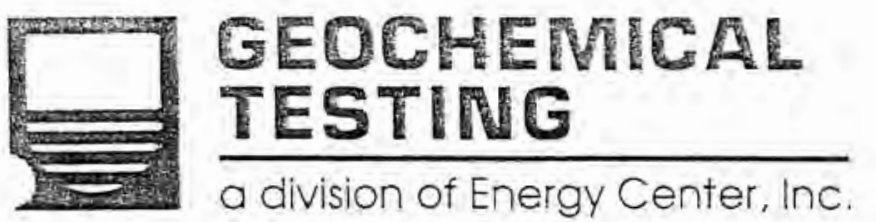

2005 N Center Ave Somerset PA 15501

$814 / 443-1671$

$814 / 445-6666$

FAX: 814/445-6729

COAL ANALYSIS REPORT

Client: US GEOLOGICAI SURVEY-CO (MCHG)

Sampled by: E.R. Landis

Sampling Date: $12 / 16 / 98$ TO $12 / 16 / 98$

Analyzed on: $12 / 31 / 98$

Description: Visonta East II Mine Sample V9

LAB NO. $98-012018$

Air Dry Loss............ 29.34 \%
Residual Moisture........ $4.46 \%$

As Received

Dry

Dry Ash-Eree

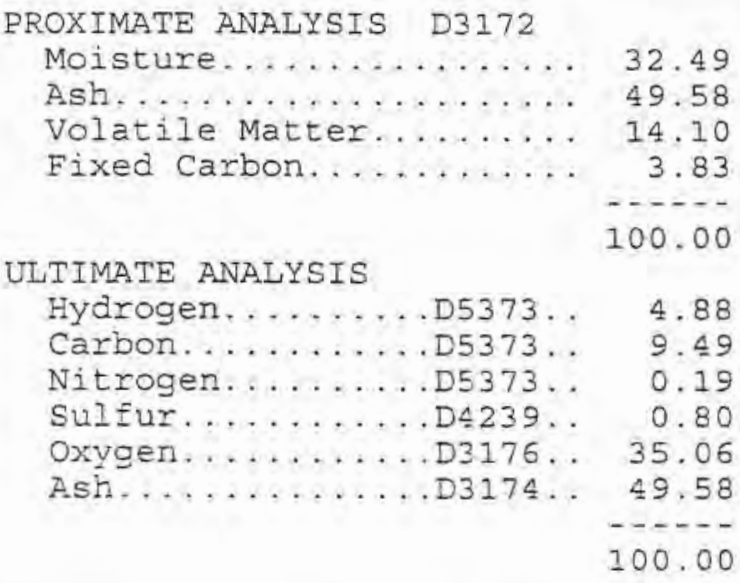

Heating Value(BTU/Lb) D1989 1679

FORMS OF SULFUR D2492

Sulfate Sulfur......... 0.12

Pyritic sulfur......... 0.45

Organic sulfur......... 0.23

Free Swelling Index D720

Equilibrium Moisture D1412-93

Hardgrove Grind. Index D409

\section{$M E M B E R$}

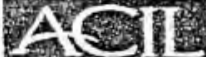

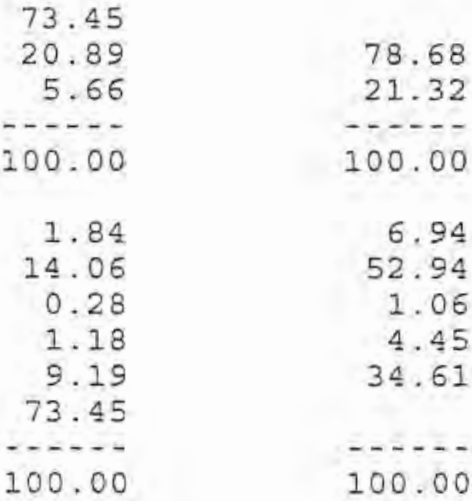

2487

9366

0.18

0.67

0.66

2. 48

1. 30

0.5

31.46

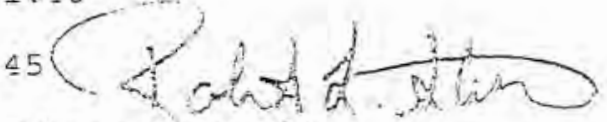

Robert I. StuII

Director of Coal Services 


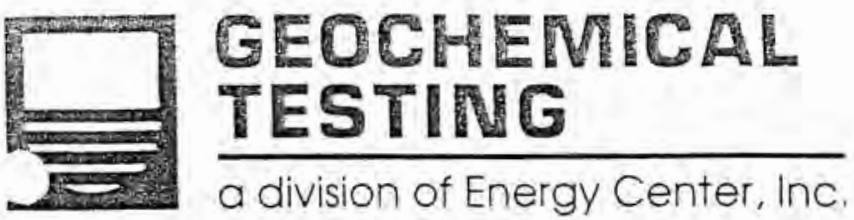

2005 N Center Ave Somerset PA 15501

814/443-1671

814/445-6666

FAX: 814/445-6729

COAL ANALYSIS REPORT

Client: US GEOLOGICAL SURVEY-CO (MCHG)

Sampled by: E.R. Landis

Sampling Date: 12/16/98 TO 12/16/98

Analyzed on: $12 / 31 / 98$

Description: Visonta East II Mine Sample V9

LAB NO. 98-012018

Ash Fusion (Reducing Atmosphere)

Temp of $\begin{array}{ccccc}\text { Initial D. Softening T. } & \text { Hemi T. Fluid T } \\ 2450 & 2540 & 2650 & 2730\end{array}$

Ash Fusion (Oxidizing Atmosphere)

Initial D. Softening T. Hemi $T$. Fluid $T$.

Temp o F $2590 \quad 2660$

2720

2790

Apparent Specific Gravity .... 1.43 
2005 N Center Ave Somerset PA 15501

814/443-1671

$814 / 445-6666$

FAX: 814/445-6729

COAL ANAIYSIS REPORT

Client: US GEOLOGICAI SURVEY-CO (MCHG)

Sampled by: E.R. Landis

Sampling Date: 12/16/98 To $12 / 16 / 98$

Analyzed on: $12 / 31 / 98$

Description: Visonta East II Mine Sample V10

LAB NO. $98-012019$

Air Dry Loss............. $38.89 \%$

Residual Moisture........ $6.10 \%$

As Received

Dry

Dry Ash-Free

PROXIMATE ANALYSIS D3172

Moisture............. 42.62

Ash................. 16.08

Volatile Matter........ 25.27

Fixed Carbon............ 16.03

-......

ULTIMATE ANAIYSIS

100.00

Hydrogen.......DD5373.. 7.05

Carbon..........D5373.. 26.82

Nitrogen........D5373... 0.44

Sulfur.........D4239.. 2.16

Oxygen..........D3176.. 47.45

Ash...........D3174.. 16.08

.......

100.00

28.02

44.05

27.93

.......

100.00

3.97

46.74

0.77

3.77

16.73

28.02

-......

100.00

8265

0.28

1.83

1. $6 E$

2. 54

2. 32

Free Swelling Index D720

Equilibrium Moisture D1412-93

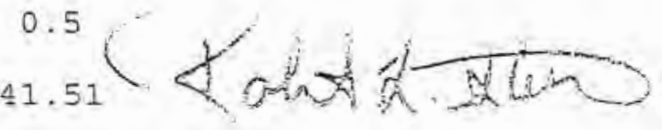

Robert I. Stull

Director of coal Services 


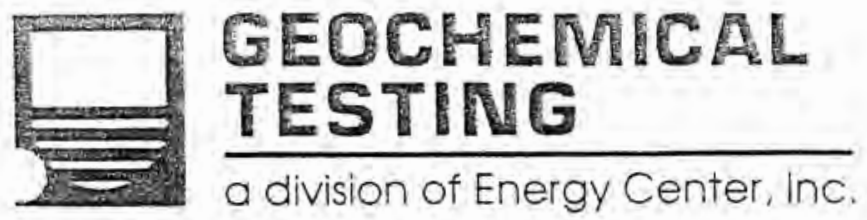

COAI ANALYSIS REPORT
2005 N Center Ave Somerset PA 15501

814/443-1671

814/445-6666

FAX: 814/445-6729

Client: US GEOLOGICAL SURVEY-CO (MCHG)

Sampled by: E.R. Landis

Sampling Date: $12 / 16 / 98$ To $12 / 16 / 98$

Analyzed on: $12 / 31 / 98$

Description: Visonta East II Mine Sample V10

LAB NO. 98-012019

Ash Fusion (Reducing Atmosphere)

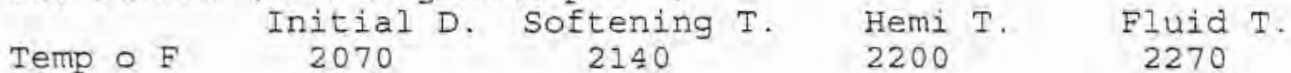

Ash Fusion (Oxidizing Atmosphere)

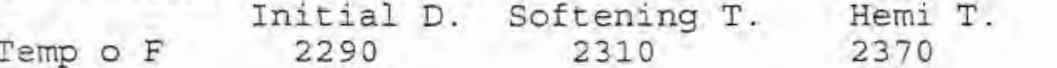

Apparent Specific Gravity .... 1.49

NOTE. Insufficient material to run HGI.

Page: 2 


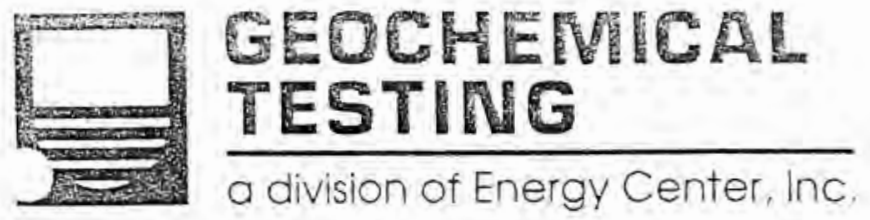

COAI, ANALYSIS REPORT
2005 N Center Ave Somerset PA 15501

814/443-1671

$814 / 445-6666$

FAX: 814/445-6729

Client: US GEOLOGICAI SURVEY-CO (MCHG)

Sampled by: E.R. Landis

Sampling Date: 12/17/98 TO 12/17/98

Analyzed on: 01/02/99

Description: Visonta East II Mine VII

LAB NO. 99-012106

Air Dry Loss............ 27.09 \%

Residual Moisture........ $4.40 \%$

As Received

Dry

Dry Ash-Free

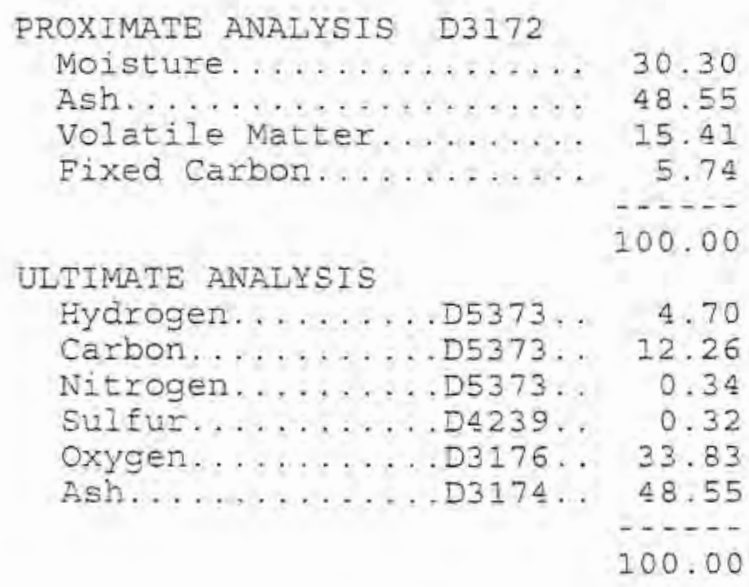

1.88

17.59

0.48

0.46

9. 94

69.65

100.00

72.84

27.16

-.....

100.00

6.20

57.98

1.59

1.52

32.72

-.....

100.00

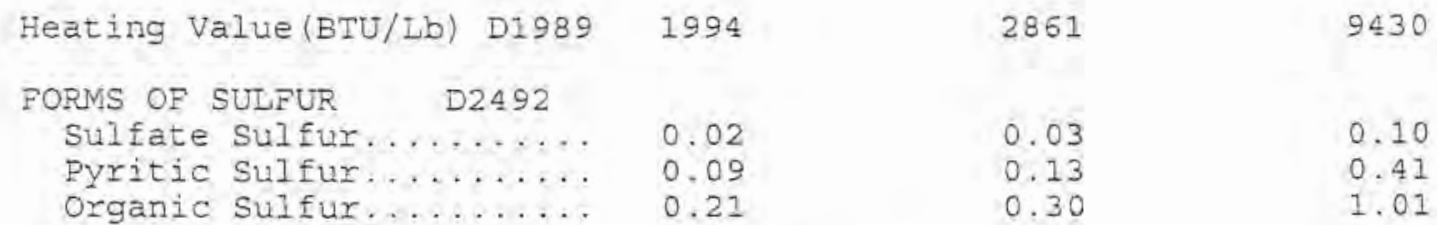

Free Swelling Index D720

0.0

Equilibrium Moisture D1412-93

32.88<smiles>CC1CCCCCCC1=O</smiles>

Robert I. Stull

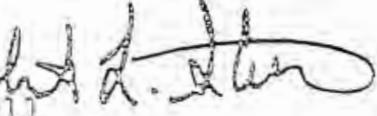

Director of Coal Services 


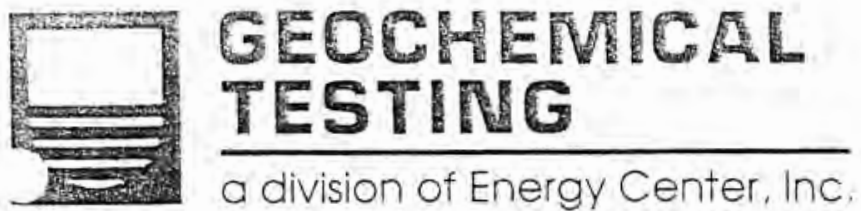

2005 N Center Ave Somerset PA 15501

814/443-1671

$814 / 445-6666$

FAX: 814/445-6729

COAI ANALYSIS REPORT
Page: 2

Client: US GEOLOGICAI SURVEY-CO (MCHG)

Sampled by: E.R. Landis

Sampling Date: $12 / 17 / 98$ To $12 / 17 / 98$

Analyzed on: $01 / 02 / 99$

Description: Visonta East II Mine V11

LAB NO+ 99-012106

Ash Fusion (Reducing Atmosphere)

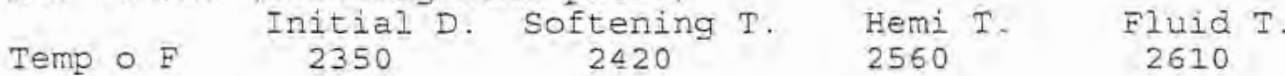

Ash Eusion (Oxidizing Atmosphere)

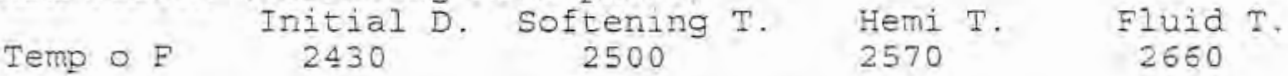

Apparent Specific Gravity .... 1.45

NOTE: Insufficent material to run HGI. 

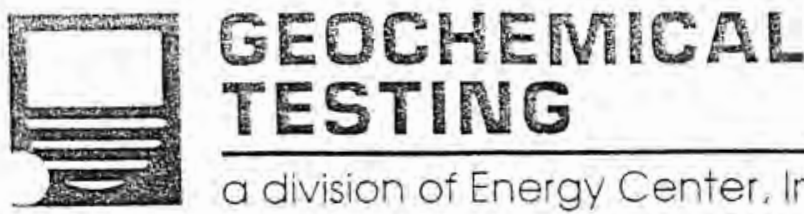

2005 N Center Ave Somerset PA 15501

$814 / 443-1671$

$814 / 445-6666$

a division of Energy Center. Inc.

FAX: $814 / 445-6729$

COAL ANALYSIS REPORT

Client: US GEOLOGICAI SURVEY-CO (MCHG)

Sampled by: E.R. Landis

Sampling Date: 12/17/98 TO 12/17/98

Analyzed on: $01 / 02 / 99$

Description: Visonta East II Mine V12

LAB NO. 99-012107

Air Dry Loss.............. $41.09 \%$
Residual Moisture......... $6.88 \%$

As Received

Dry

Dry Ash-Free

PROXIMATE ANALYSIS D3172

Moisture............. 45.14

Ash .............. 5.48

Volatile Matter......... 29.10

Fixed Carbon........... 20.28

- - . . -

ULTIMATE AINAIYSIS

100.00

Hydrogen.......D5373. 7.70

Carbon.........D5373.. 32.77

Nitiogen..........D5373 . 0.62

Sul fur.................. 0.58

Oxygen..........D3175. 52.85

Ash..........D3I74..

5.48

$\ldots . . .$.

100.00

10.00

53.05

36.95

58.94

41.06

......

......

100.00

4.82

5.36

59.73

1. 14

66.36

1. 26

1.06

1. 18

23.25

10.00

25.84

$\ldots . . .$.

.......

200.00

100.00

Heating Value (BTU/Lib) D1989 5555

10125

11250

FORMS OF SULFUR D2 492

$\begin{array}{ll}\text { Sulfate Sulfur........... } & 0.02 \\ \text { Pyritic Sulfur........... } & 0.03\end{array}$

Organic sulfur......... 0.53

0.03

0.05

0.04

0.98

0.06

1. 08

Free Swelling Index D720

0.0

Equilibrium Moisture D1422-93

Hardgrove Grind. Index D409

MEMBER

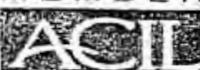

42.70

43

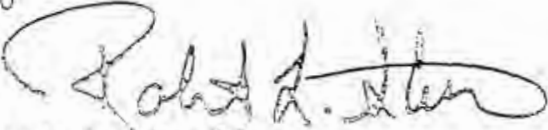

Robert I. Stul1

Director of Coal Services 


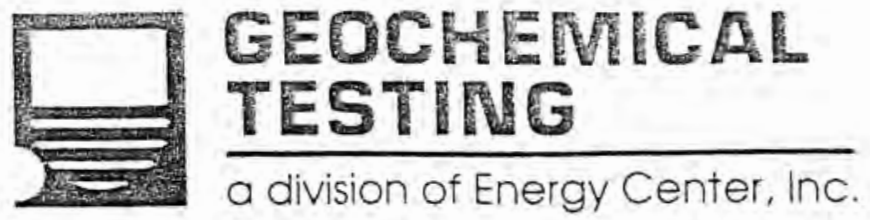

COAL ANALYSIS REPORT
2005 N Center Ave Somerset PA 15501

814/443-1671

$814 / 445-6666$

FAX: 814/445-6729

Client: US GEOLOGICAL SURVEY-CO (MCHG)

Sampled by: E.R. Landis

Sampling Date: $12 / 17 / 98$ To $12 / 17 / 98$

Analyzed on: 01/02/99

Description: Visonta East II Mine V12

LAB NO. 99-012107

Ash Fusion (Reducing Atmosphere)

Temp of $\quad \begin{array}{cc}\text { Initial D. } & \text { Softening } \\ 2420 & 2460\end{array}$

Ash Fusion (Oxidizing Atmosphere)

$\begin{array}{lcr}\text { Temp o F } & 2470 & 2480\end{array}$

Hemi T. Fluid $T$.

2470

2490

Fluid $T$. 2510

Apparent Specific Gravity .... $\quad 1.05$ 
